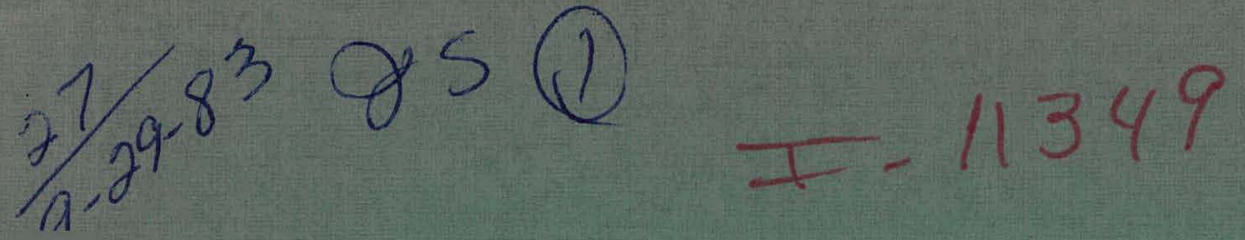

Dr. 1790-6 PNL-4333

UC-70

\title{
Validation of the WATEQ4 Geochemical Model for Uranium
}

K. M. Krupka

E. A. Jenne

W. J. Deutsch

September 1983

Prepared for the U.S. Department of Energy under Contract DE-AC06-76RLO 1830

Pacific Northwest Laboratory Operated for the U.S. Department of Energy by Battelle Memorial Institute

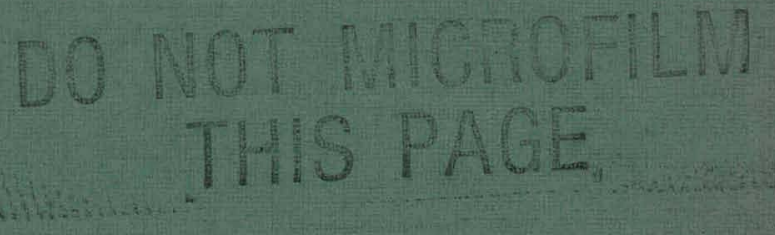




\section{DISCLAIMER}

This report was prepared as an account of work sponsored by an agency of the United States Government. Neither the United States Government nor any agency Thereof, nor any of their employees, makes any warranty, express or implied, or assumes any legal liability or responsibility for the accuracy, completeness, or usefulness of any information, apparatus, product, or process disclosed, or represents that its use would not infringe privately owned rights. Reference herein to any specific commercial product, process, or service by trade name, trademark, manufacturer, or otherwise does not necessarily constitute or imply its endorsement, recommendation, or favoring by the United States Government or any agency thereof. The views and opinions of authors expressed herein do not necessarily state or reflect those of the United States Government or any agency thereof. 


\section{DISCLAIMER}

Portions of this document may be illegible in electronic image products. Images are produced from the best available original document. 


\section{The following pages are an exact representation of what is in the original document folder.}




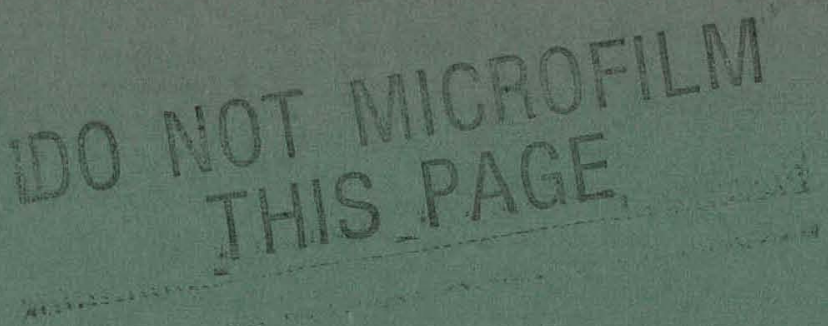

\title{
DISCLAIMER
}

This report was prepared as an account of work sponsored by an agency of the United States Government. Neither the United States Government nor any agency thereof, nor any of their employees, makes any warranty, express or implied, or assumes any legal liability or responsibility for the accuracy, completeness, or usefulness of any information, apparatus, product, or process disclosed, or represents that its use would not infringe privately owned rights. Reference herein to any specific commercial producl, process, or service by trade name, trademark, manufacturer, or otherwise, does not necessarily constitute or imply its endorsement, recommendation, or favoring by the United States Government or any agency thereof. The views and opinions of authors expressed herein do not necessarily state or reflect those of the United States Government or any agency thereof.

\author{
PACIFIC NORTHWEST LABORATORY \\ operated by \\ BATTELLE \\ for the \\ UNITED STATES DEPARTMENT OF ENERGY \\ under Contract DE-AC06-76RLO 1830
}

\begin{tabular}{|c|c|}
\hline \multicolumn{2}{|c|}{$\begin{array}{l}\text { Printed in the United Stales of America } \\
\qquad \text { Available from } \\
\text { National Technical Information Service } \\
\text { United States Department of Commerce } \\
5285 \text { Port Royal Road } \\
\text { Springfield, Virginia } 22161\end{array}$} \\
\hline \multicolumn{2}{|c|}{$\begin{array}{l}\text { NTIS Price Codes } \\
\text { Microfiche A01 }\end{array}$} \\
\hline \multicolumn{2}{|c|}{ Printed Copy } \\
\hline Pages & $\begin{array}{l}\text { Price } \\
\text { Codes }\end{array}$ \\
\hline $0 \cap 1-\cap 25$ & $\mathrm{~A} 02$ \\
\hline $026-050$ & $\mathrm{AO3}$ \\
\hline $051-075$ & $\mathrm{AO} 4$ \\
\hline $076-100$ & A05 \\
\hline $101-125$ & $\mathrm{~A} 06$ \\
\hline $126-150$ & $\mathrm{~A} 07$ \\
\hline $151-175$ & $\mathrm{~A} 08$ \\
\hline $176-200$ & A09 \\
\hline $201-225$ & A010 \\
\hline $226-250$ & A011 \\
\hline $251-275$ & A012 \\
\hline $276-300$ & A013 \\
\hline
\end{tabular}




\section{DISCLAIMER}

This report was prepared as an account of work sponsored by an agency of the United States Government. Neither the United States Government nor any agency thereof, nor any of their employees, makes any warranty, express or implied, or assumes any legal liability or responsibility for the accuracy, completeness, or usefulness of any information, apparatus, product, or process disclosed, or represents that its use would not infringe privately owned rights. Reference herein to any specific commercial product, process, or service by trade name, trademark, manufacturer, or otherwise does not necessarily constitute or imply its endorsement, recommendation, or favoring by the United States Government or any agency thereof. The views and opinions of authors expressed herein do not necessarily state or reflect those of the United States Government or any agency thereof.

\section{VALIOATION OF THE WATEQ4 GEOCHEMICAL MODEL FOR URANIUM}

\author{
K. M. Krupka \\ E. A. Jenne \\ W. J. Deutsch
}

September 1983

Prepared for

the U.S. Department of Energy under Contract DE-AC06-76RLO 1830
PNL- -4333

DE83 017997 


\section{THIS PAGE}

\section{WAS INTENTIONALLY \\ LEFT BLANK}




\section{ACKNOWLEDGEMENTS}

The authors would like to thank Drs. D. C. Girvin and J. B. Moody for their reviews of this document. Many thanks are also due to $K$. J. Carson for computer analysis of the data and to B. K. Marshall and P. R. Partch for their editorial reviews of this document. This research was supported by the Department of Energy (Contract DE-ACU6-76RLO 1830), via the Office of Nuclear Waste Isolation (ONWI). 


\section{EXECUTIVE SUMMARY}

As part of the Geochemical Modeling and Nuclide/Rock/Groundwater Interactions Studies (GMIS) Program,(a) a study was conducted to partially validate the WATEQ4 aqueous speciation-solubility geochemical model(b) for uranium. The purpose of this study was to:

- document the agreement or disagreement between solubility controls for uranium as calculated by the WATEQ4 model with those found in published laboratory solubility experiments and studies of natural water-rock systems,

- "determine and correct any deficiencies in the model, its computer code, and, to the extent possible, its thermodynamic data base, when satisfactory agreement is not obtained for a number of adequate water analyses having characterized uranium solid phases as reaction materials or products,

- identify additional data needed to achieve an acceptable level of model validation for uranium.

Studies such as this are an essential step in providing validated, computerized models for assessing the performance of high-level nuclear waste repositories.

Considerable time was spent during this study examining published laboratory solubility and field geochemical studies to determine which investigations contained data that were adequate for geochemical model validation. The studies were evaluated according to the following selection criteria: 1) a uranium-bearing solid had to have been physically identified as contributing to the chemistry of the aqueous system; and 2) analytical analyses had to include, at a minimum, total dissolved uranium, $\mathrm{pH}$, redox potential [except for $U(V I)$ studies], and temperature.' After the aqueous solutions and ground waters were selected from the published studies, the WATEQ4 model was then used to

(a) The GMIS Program is supported by the U.S. Department of Energy through the Office of Nuclear Waste Isolation (ONWI).

(b) An aqueous speciation-solubility model calculates the distribution of aqueous species and then tests the hypothesis that the water is near equilibrium with particular solid phases. 
calculate the degree to which the solutions or waters were apparently saturated with those uranium solids present in the WATEQ4 thermodynamic data base. The resulting permissible solubility controls were compared to those identified in the laboratory and field investigations.

The solubility controls determined with the WATEQ4 geochemical model were in excellent agreement with those laboratory studies in which the solids schoepite $\left[\mathrm{UO}_{2}(\mathrm{OH})_{2} \cdot \mathrm{H}_{2} \mathrm{O}\right], \mathrm{UO}_{2}(\mathrm{OH})_{2}$, and rutherfordine $\left(\mathrm{UO}_{2} \mathrm{CO}_{3}\right)$ were identified as the actual solubility controls for uranium. The results of modeling solution analyses trom laboratory studies of uranyl phosphate solids, however, identificd possible errors in the characterization of solids in the original solubility experiments. This validation study has also conflrmed the prubable precipitation of sodium uranates in several solubility studies where sodium hydroxide was used to neutralize acids. In accord with the findings of other investigators, ground waters associated with known deposits of uraninite $\left(\mathrm{UO}_{2}\right)$ were calculated to be generally oversaturated with uraninite. In addition, the apparent discrepancy between the modeling results and mineralogical data for U(IV) minerals may have to be resolved through further characterization of the uranium solids at the sites of the ground-water samples.

As part of this study, significant deficiencies in the WATEU4 thermodynamic data base for uranium solutes and solids were corrected. Revisions included recalculation of selected uranium reactions. Additionally, thermodyramic data for the hydroxyl complexes of U(VI), including anionic (VI) species, were evaluated (to the extent permitted by the avallable data). Vanadium reactions were also added to the thermodynamic data base because uranium-vanadium solids can exist in natural ground-water systems.

This study is only a partial validation of the WATEQ4 geochemical model because the available laboratory solubility studies do not cover the range of solid phases, dikaline $\mathrm{pH}$ values, and curcentrations of innrganic complexing ligands needed to evaluate the potential solubility of uranium in ground waters associated with various proposed nuclear waste repositories. Further validatiun of this or other geochemical models for uranium will require careful determinations of uraninite solubility over the $\mathrm{pH}$ range of 7 to 10 under 
highly reducing conditions and of uranyl hydroxide and phosphate solubilities over the $\mathrm{pH}$ range of 7 to 10 under oxygenated conditions. 
ACKNOWLEDGMENTS

i i i

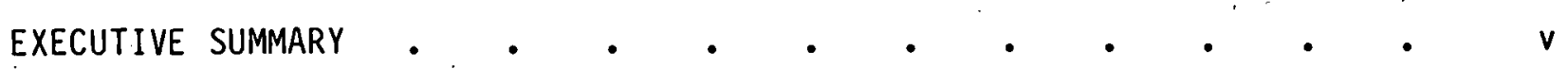

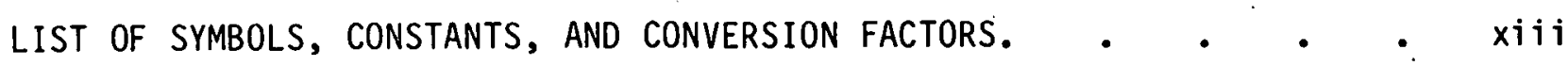

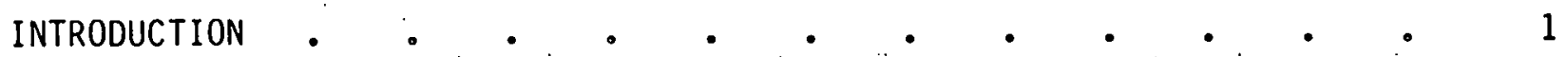

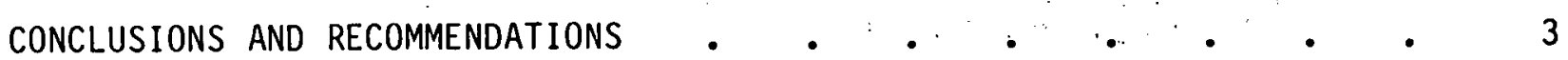

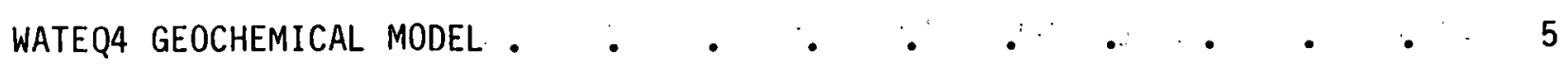

CALCULATION OF EQUILIBRIUM CONSTANTS FOR DATA BASE. $\quad$ • $\quad$ • 7

CORRECTIONS TO STABILITY CONSTANTS--TEMPERATURE AND

IONIC STRENGTH •

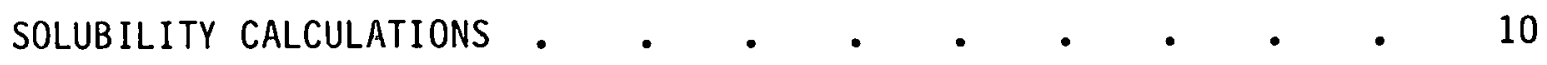

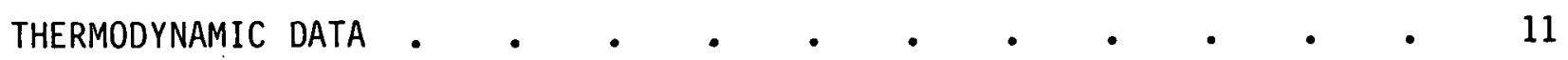

REVISIONS TO THE WATEQ4 DATA BASE FOR URANIUM. $\quad$ • $\quad$ • $\quad$ • $\quad$ - 11

SOLUTION SPECIES, COMPLEXES, AND SOLIDS OF VANADIUM • • • • 15

PUBLISHED LABORATORY SOLUBILITY AND GROUND-WATER DATA • • • • • 17

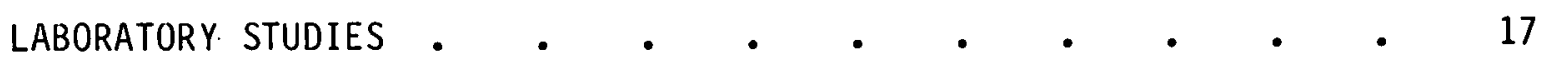

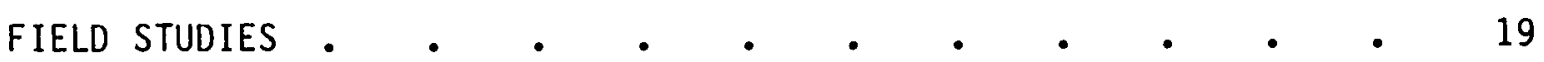

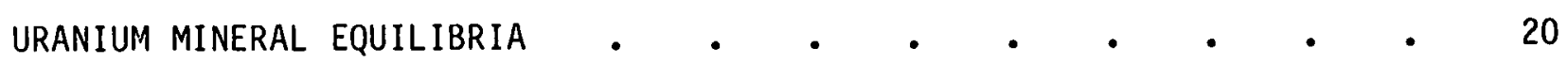

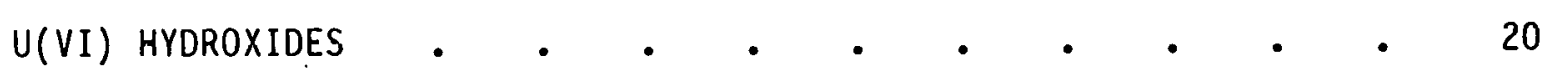

EFFECTS OF HYDROXYL COMPLEXATION ON SOLUBILITIES OF

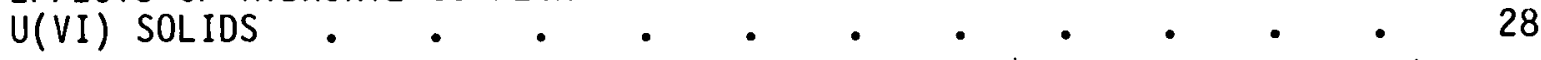

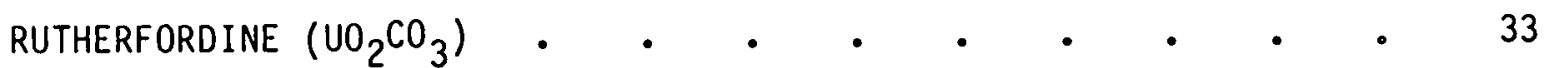

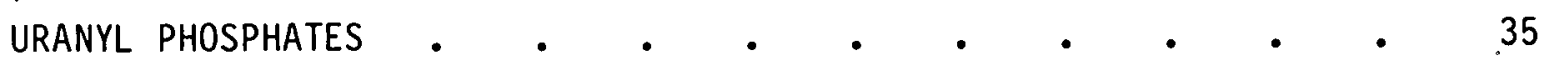

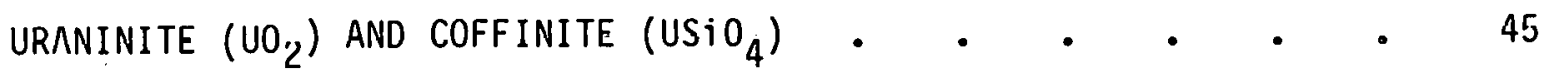

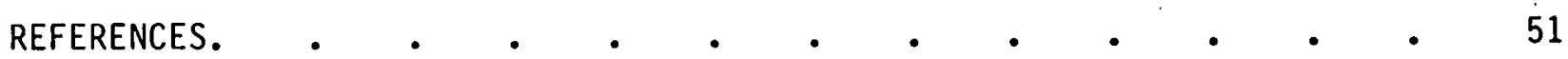

APPENDIX A - CORRECTIONS TO WATEQ3 AND ITS DOCUMENTATION $•$ • $\quad$ - A.I 


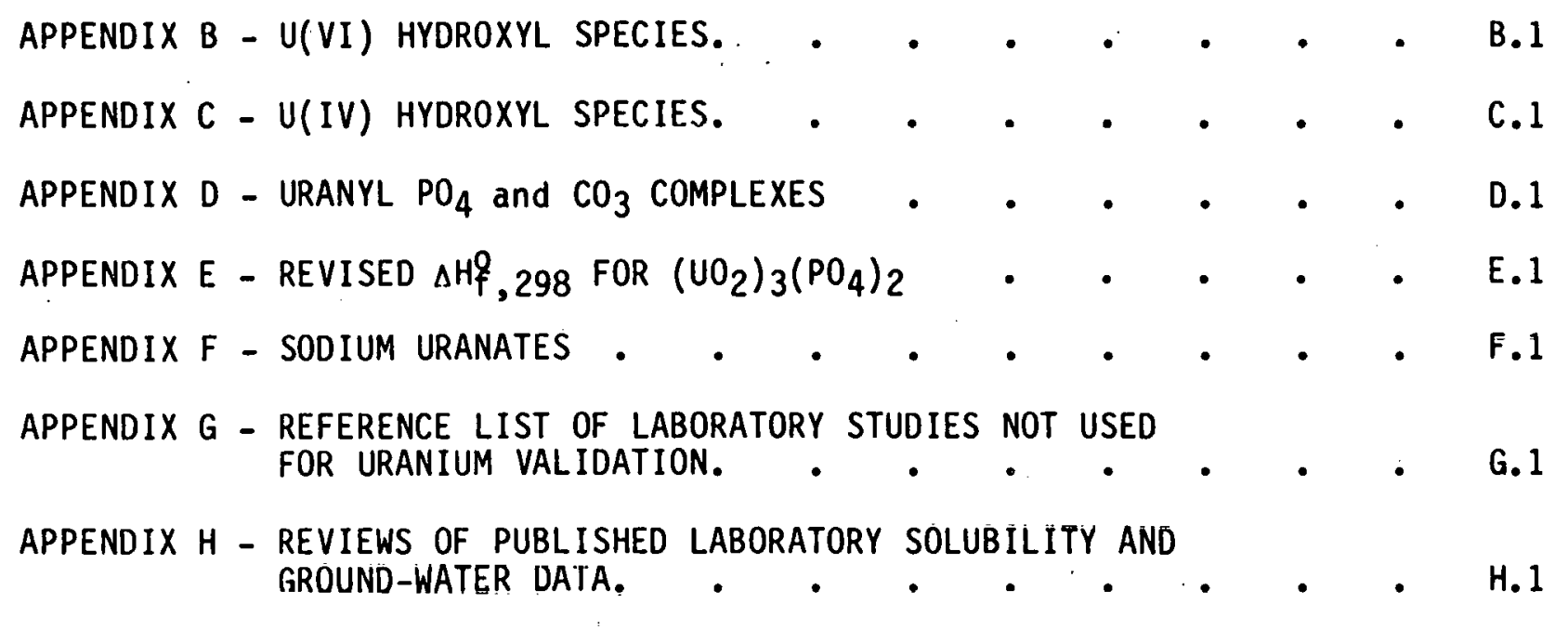




\section{FIGURES}

1 Schematic Flow Diagram for Aqueous Speciation and Solubility Submodels of WATEQ4

2. $\mathrm{UO}_{2}(\mathrm{OH})_{2}$ Saturation Indices Plotted Versus Log of Total

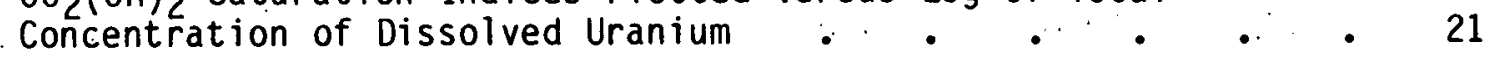

$3 \mathrm{UO}_{2}(\mathrm{OH})_{2}$ Saturation Indices Plotted Versus $\mathrm{pH} \quad . \quad \cdot \quad \cdot 25$

4 Schoepite $\left[\mathrm{UO}_{2}(\mathrm{OH})_{2} \cdot \mathrm{H}_{2} \mathrm{O}\right]$ Saturation Indices Plotted Versuis $\mathrm{pH}$.

5 Total Concentration of Dissolved Uranium in Equilibrium at $25^{\circ} \mathrm{C}$ with Schoepite $\left[\mathrm{UO}_{2}(\mathrm{OH})_{2} \cdot \mathrm{H}_{2} \mathrm{O}\right]$ as a Function of $\mathrm{pH}^{\prime} \cdot \because \cdot 30$

6 Rutherfordine $\left(\mathrm{UO}_{2} \mathrm{CO}_{3}\right)$ Saturation Indices Plotted

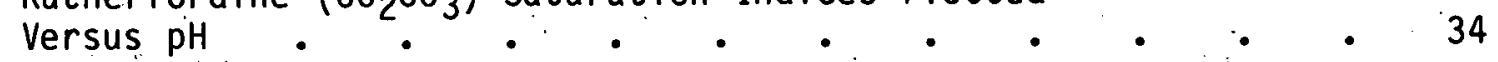

7 Saturation Indices for $\mathrm{H}$-Autunite and $\left(\mathrm{UO}_{2}\right)_{3}\left(\mathrm{PO}_{4}\right)_{2}$ Plotted as a Function of $\mathrm{pH} . \quad \cdot \quad \cdot \quad \cdot \quad \cdot \quad \cdot \quad \cdot \quad \cdot$.

8 Activity of the Aqueous Species $40_{2}^{2+}$ in Equilibrium at $25^{\circ} \mathrm{C}$ with H-Autunite, $\left(\mathrm{UO}_{2}\right)_{3}\left(\mathrm{PO}_{4}\right)_{2}$, and Schoepite as a Function

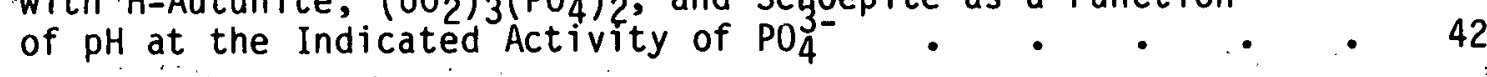

9 Uraninite Saturation Indices Plotted Versus Total Concentration of Dissolved Uranium. • • • • • • • • • 47

10 Maximum Concentrations of Dissolved Uranium in Equilibrium with

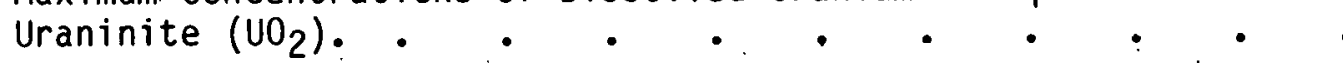

C.I Comparison of Step-Wise Stability Constants at $25^{\circ} \mathrm{C}$ for U(IV)Hydroxyl Complexes Estimated from the Data of Tremaine et al. (1981) Versus Those Given in Other Tabulations of Thermodynamic Data

\section{TABLES}

1 Aqueous Species and Solids of Uranium in the Thermodynamic Data Base of WATEQ3 (Ball, Jenne, and Cantrell 1981) • • • •

2 Saturation Indices for Selected Uranium Solids Calculated for Solution Analyses from Published Laboratory Studies of Uranyl Phosphates. 
H.1 Solution Analyses Modeled from Brush (1980) and Saturation Indices for Selected Uranium Solids . . . . . . H.3

H. $2 a$ Solution Analyses Modeled from Chukhlantsev and

Stepanov (1956)

H. 2b Saturation Indices for Selected Uranium Solids for Solution Analyses Modeled from Chukhlantsev and Stepanov (1956). . . H.6

H.3 Solution Analyses Modeled from Gayer and Leider (1955) and Saturation Indices for Selected Uranium Minerals. - . . H.8

H.4 Solution Analyses Modeled from Miller (1958) and Saturation Indices for Selected Uranium Minerals - • • • • . H.12

H. 5a Solution Analyses Modeled from Moskvin, Shelyakina, and Perminov (1967) • • • • • • • • • • H.15

H.5b Saturation Indices for Selected Uranium Solids for Solution Analyses Mndeled from Moskvin, Shelyakina, and Perminov (1967) . H.16

H.6a Solution Analyses Modeled from Muto (1965) . . . . . H.18

H.6b Saturation Indices for Selected Uranium Solids for Solution Analyses Modeled from Muto (1965). . . . . . . H.18

H.7 Solution Analyses Modeled from Robins (1966) and Saturation Indices for Selected Uranium Solids . . . . . . H.20 H.8 Solution Analyses Modeled fromi Sergeyeva et al. (1972) and
Saturation Indices for Selected Uranium Solids : • H.22

H.9a Solution Analyses Modeled from Chatham, Wanty, and Langmuir (1981) • • • • • • • • • • H.27

H.9b Saturation Indices for Selected Uranium Solids for Solution
Analyses Modeled from Chatham, Wanty, and Langmuir (1981). . H.28

H.10a Solution Analyses Modeled from Păces (1969). . . . . H.30

H.10b Saturation Indices for Selected Uranium Solids for Solution Arialyses Modeled from Păces (1969) . . . . . . H.31 


\section{LIST OF SYMBOLS, CONSTANTS, AND CONVERSION FACTORS}

$a_{i} \quad$ Activity of species $i$.

(a) Descriptor for amorphic solid. Amorphic is defined as amorphous-like with minimal $X$-ray diffraction pattern.

(am) Descriptor for amorphous solid that gives no X-ray diffraction pattern. Most references do not differentiate between 'a' and 'am.'

AP Activity product for stoichiometry of species in the dissolution or precipitation reaction for the specified solid.

(c) Descriptor for a crystalline solid.

cal Thermochemical calorie, unit of energy, where 1 cal $=4.1840$ joules absolute.

Heat capacity per mol at constant pressure.

$\Delta C_{P}^{0}$

Change in heat capacity for that specified reaction.

$\mathrm{e}^{-}$

Electron.

$E^{H}$

Electrical potential of an aqueous system relative to the standard hydrogen electrode. Accompanying subscripts may be used to differentiate between different sources of the $E^{H}$ value $\left(e . g ., E_{p t}\right.$ for the platinum electrode and $E_{F e}$ (II) for the $\mathrm{Fe}$ (II)/Fe(III) redox couple).

Faraday constant, 23,061 cal $\mathrm{V}^{-1} \cdot \mathrm{mol}^{-1}$.

Descriptor for compounds in the gaseous state.

$\gamma_{i}$

Activity coefficient of species $i$.

(gl) Descriptor for glass-like solid.

$\triangle G q, T$ Gibbs free energy of formation at temperature $T$ from the elements.

$\Delta G_{r, T}^{0} \quad$ Change in Gibbs free energy of formation for that specified reaction at temperature $T$.

$\Delta H_{f, T}^{0} \quad$ Heat or enthalpy of formation at temperature $T$ from the elements.

$\Delta H_{r, T}^{0} \quad$ Change in heat of formation for that specified reaction at temperature $\mathrm{T}$.

K Temperature in degrees Kelvin. 


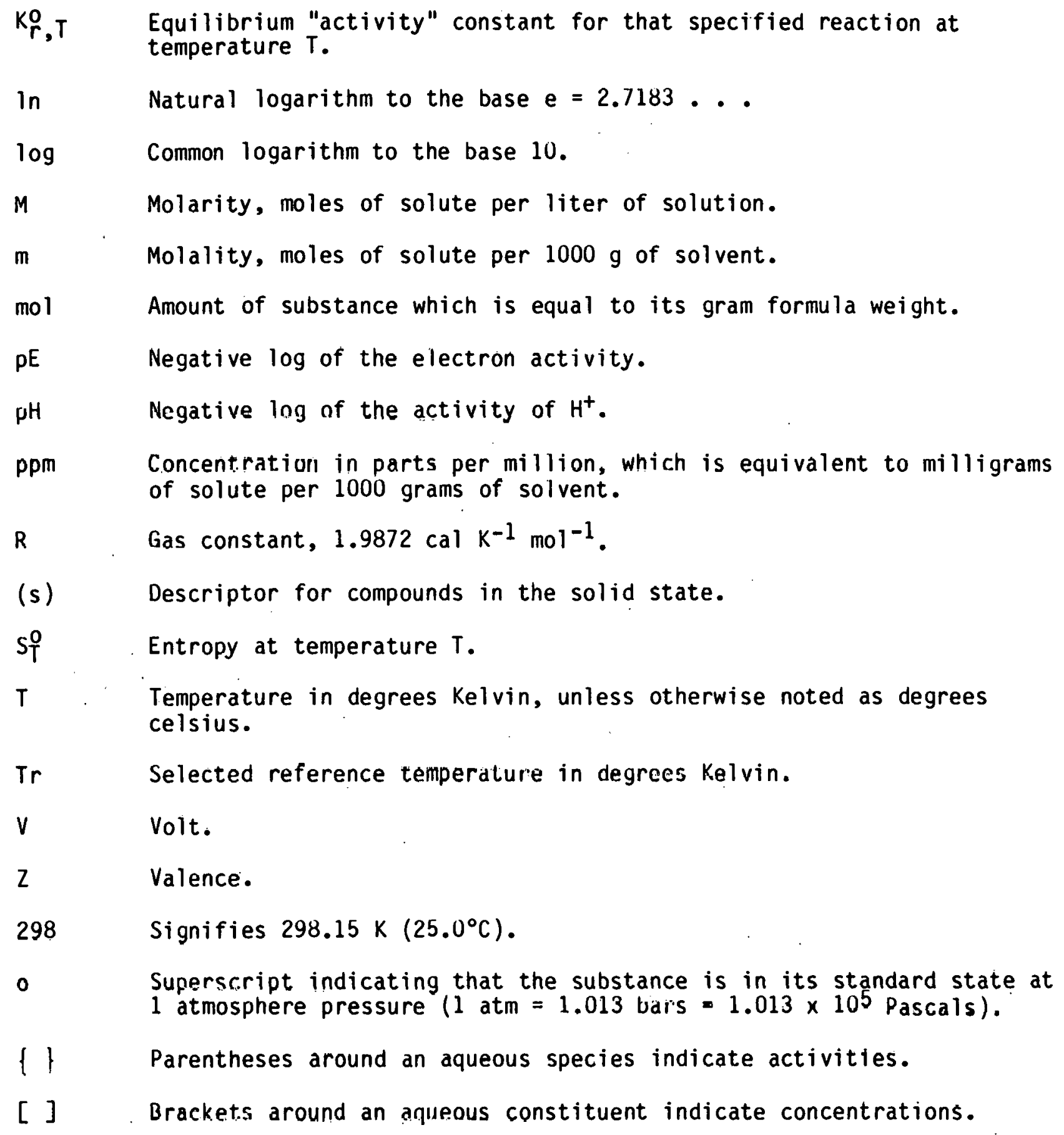


INTRODUCTION

Geochemical models are used to predict the behavior of dissolved constituents in natural waters and laboratory solutions. In turn, this information is used to establish baseline geochemical conditions for potential repository sites and to simulate the geochemical behavior of transported radionuclides. At a minimum, these models must calculate for a given ground water: 1) speciation of dissolved constituents into their various complexes, 2) solids in solubility equilibrium with this aqueous solution, 3) adsorption of dissolved constituents, and 4) mass transfer as a result of precipitation and dissolution, all as a function of $\mathrm{pH}$, redox potential, temperature, and ionic strength. The accuracy with which a geochemical model simulates actual processes must be established and documented to demonstrate its ability to assess the performance of potential geologic sites as repositories of nuclear waste. Validation is the term used for an integrated test of the accuracy of the geochemical model, its computer code, and its thermodynamic data base in simulating appropriate field and experimental observations. As part of the Geochemical Modeling and Nuclide/Rock/Groundwater Interaction Studies (GMIS) Program(a) at Pacific Northwest Laboratory, such a validation study was conducted for the aqueous speciation-solubility geochemical model known as WATEQ4.

The potential for migration of radionuclides away from a repository is determined in part by the dissolution rate of the waste form, solubility of one or more solid forms of the radionuclides, adsorption, and the rate of water flow. The purpose of this validation study was to: 1) document the agreement or disagreement between solubility controls as calculated by the geochemical model with those determined from laboratory solubility studies or natural water-rock systems, and 2) determine and correct deficiencies in the model,(b)

(a) Funded by the U.S. Department of Energy through the Office of Nuclear Waste Isolation (ONWI).

(b) A geochemical model is defined here as the integration of mathematical expressions describing theoretical concepts and thermodynamic relationships on which the speciation, adsorption, solubility, and mass transfer calculations are based. A geochemical code refers to the translation of a geochemical model into a sequence of computer language statements. 
its thermodynamic data base, and its code, when satisfactory agreement was not obtained for an adequate water analysis with well-characterized solubility controls. For this validation study, aqueous speciation and solubility controls were modeled for laboratory solutions and ground waters containing uranium. Uranium was chosen for the initial validation study because:

1) uranium is both a significant component of radioactive wastes and, along with its daughter products, exhibits appreciable toxicity; and 2) the thermodynamic data at $25^{\circ} \mathrm{C}$ for aqueous species and solid phases containing uranium are well known relative to those for the other actinides. Only aqueous solutions with ionic strengths less than approximately 0.5 and with temperatures less than $100^{\circ} \mathrm{C}$ were used for the validation study; these are the current limitations for ionic strength corrections in must geochcmicale models and for temperature corrections to equilibrium constants in WATEQ4.

This report describes: 1) the WATEQ4 geochemical model, 2) the WATEQ4 thermodynamic data base (including revisions) for aqueous species and solids of uranium, 3) the published laboratory and field studies used in the uranium validation, and 4) the results of the solubility controls calculated by the WATEQ4 model for the selected water analyses. These discussions help to demonstrate the major dependency between the results of the validation study and the triad that includes the geochemical model, its thermodynamic data base, and the data from the available solubility studies.

After this validation study was started, the thermudynamic data base and many other features of WATEQ4 were combined with the mass-transfer mathematics of MINEQL (Westall, Zachary, and Morel 1976) to form the geochemrcal model known as MINTEQ. (a) We expect that MINTEQ will be used in the performance. assessment of proposed nuclear waste repositories. This partial validation analysis of the WATEQ4 model from published sulubility studies, which are included in the appendices of this report, will render equivalent uranium validation studies of MINTEQ or other genchemical models, a comparatively minor effort.

(a) Felmy, A. R., D. C. Girvin, and E. A. Jenne. (In preparation). MINTEQ - A Computer Program for Calculating Geochemical Equilibria. PNL Report. Pacific Northwest Laboratory, Richland, Washington. 
The permissible solubility controls for uranium as calculated with the WATEQ4 geochemical model were in excellent agreement with laboratory studies in which the uranyl, $\mathrm{U}(\mathrm{VI})$, solids schoepite $\left[\mathrm{UO}_{2}(\mathrm{OH})_{2} \cdot \mathrm{H}_{2} \mathrm{O}\right], \mathrm{UO}_{2}(\mathrm{OH})_{2}$, and rutherfordine $\left(\mathrm{UO}_{2} \mathrm{CO}_{3}\right)$ were identified as the actual solubility controls. Modeling of the solution analyses of the laboratory solubility studies of uranyl phosphate solids has identified possible limitations in the original solubility experiments. In particular, calculated solubility relations between $\mathrm{H}$-autunite $\left[\mathrm{H}_{2}\left(\mathrm{UO}_{2}\right)_{2}\left(\mathrm{PO}_{4}\right)_{2}\right],\left(\mathrm{UO}_{2}\right)_{3}\left(\mathrm{PO}_{4}\right)_{2}$, and schoepite suggest that certain investigators may have incorrectly identified the equilibrium solubility controls for uranium and phosphate in dissolution experiments involving $\mathrm{H}$-autunite and $\left(\mathrm{UO}_{2}\right)_{3}\left(\mathrm{PO}_{4}\right)_{2}$. Additional thermodynamic data are needed to permit reliable solubility modeling of sodium uranates. However, this modeling study supports the possibility that sodium uranates frequently form when sodium hydroxide is used to neutralize uranium-bearing acidic solutions.

Sensitivity analyses carried out with the WATEQ4 geochemical model demonstrate that the inclusion of anionic U(VI) hydroxyl species [e.g., $\left.\left(\mathrm{UO}_{2}\right)_{3}(\mathrm{OH})_{7}\right]$ significantly increases the maximum concentration of dissolved uranium in equilibrium with U(VI) solids in high pH waters. However, available lapboratory solubility studies of uranium in high pH solutions are inadequate to evaluate the existence of anionic and/or neutral hydroxyl complexes for U(VI). Therefore, further solubility studies of uranyl hydroxide solids in high $\mathrm{pH}$ solutions should be conducted to assess the existence of anionic hydroxyl U(VI) complexes. Analyses of dissolved constituents other than those determined in past studics are needed. These results will be more easily interpreted if the solutions are free of alkali metals and complexing ligands other than hydroxyl ions.

Ground waters associated with known deposits of uraninite $\left(\mathrm{UO}_{2}\right)$ were calculated to be generally oversaturated with uraninite. This is in accord with previous geochemical modeling studies of these same ground-water samples. This apparent discrepancy between the modeling results and mineralogical data for $U(I V)$ minerals may be resolved through further characterization of the 
uranium solids at the sites of the ground-water samples and/or through laboratory solubility studies of unoxidized samples of the ore itself. Insufficient laboratory and field studies of dissolved U(IV) in reducing waters with measured values of $\mathrm{pH}$ and redox potential exist to evaluate either the solubility data for U(IV) solids (including uraninite) or the hydroxyl complexes of U(IV) that have been derived from experimental solubility data for $\mathrm{UO}_{2} \cdot$ Therefore, the use of geochemical models to estimate maximum uranium concentrations in reducing ground waters associated with nuclear waste repositories requires additional laboratory and field studies. Furthermore, the equilibrium constants for U(IV) hydroxyl species should also be experimentally determined, preferably independent of solubility mcasurement.s on U(IV) solids. Finally, thermodynamic data tor U(VI) jhosphatee shouln be re-evaluated.

In summary, the WATEQ4 geochemical model has been partially validated for uranium. The additional experimental data and thermodynamic data reviews needed to permit an acceptable level of validation of geochemical models for expected nuclear waste repository conditions have been identified. Validation studies of models such as this one need to be made on a recurring basis as additional solubility data become avallable. In this way, the general scientific and professional communities can be assured of the reliability of such genchemical models and cain evaluate the safety of underground nuclear waste repositories. 
WATEQ4 GEOCHEMICAL MODEL

WATEQ4, a speciation-solubility model, was developed recently at Pacific Northwest Laboratory. This model contains the WATEQ3 data base (Ball, Jenne, and Cantrell 1981) and is written in the PL/1 computer language used for the earlier codes WATEQ (Truesdell and Jones 1974), WATEQ2 (Bal1, Nordstrom, and Jenne 1980), and WATEQ3 (Ball, Jenne, and Cantrel1 1981). The WATEQ4 code differs fundamentally from earlier WATEQ codes in two major ways. First; the reactions and equilibrium constants used to calculate the activity products for aqueous species and solids are stored external to the WATEQ4 code. When a water composition is modeled with WATEQ4, only those thermodynamic data pertinent to the aqueous species and solids of the analytically determined constituents are stored in memory. These data in memory are then accessed by WATEQ4 through a data-connective structure. This has the advantages of greatly reducing the required computer memory and execution time, and of increasing the ease with which new reactions and attendant thermodynamic data can be added to the code. Second, WATEQ4 uses the Newton-Raphson iterative procedure to solve the system of mass action and mass balance equations necessary to calculate aqueous speciation. An initial distribution of aqueous species is estimated by the continued fraction method used in earlier WATEQ codes (Nordstrom et al. 1979). The Newton-Raphson numerical method was added primarily to improve convergence problems encountered in WATEQ3 (Appendix A). The WATEQ4 model and its verification agains. WATEQ3 are described by Felmy et al. (a)

The WATEQ4 geochemical model has three parts--a thermodynamic data base, a spcciation submodel, and a sulubility submodel (F.igure 1). The speciation submodel first computes the activities for the uncomplexed and complexed aqueous species from an initial water composition. The activities of the

(a) Felmy, A. R. and E. A. Jenne. (In preparation). Documentation for the Speciation-Solubility Model WATEQ4. PNL Report. Pacific Northwest Laboratory, Richland, Washington. 


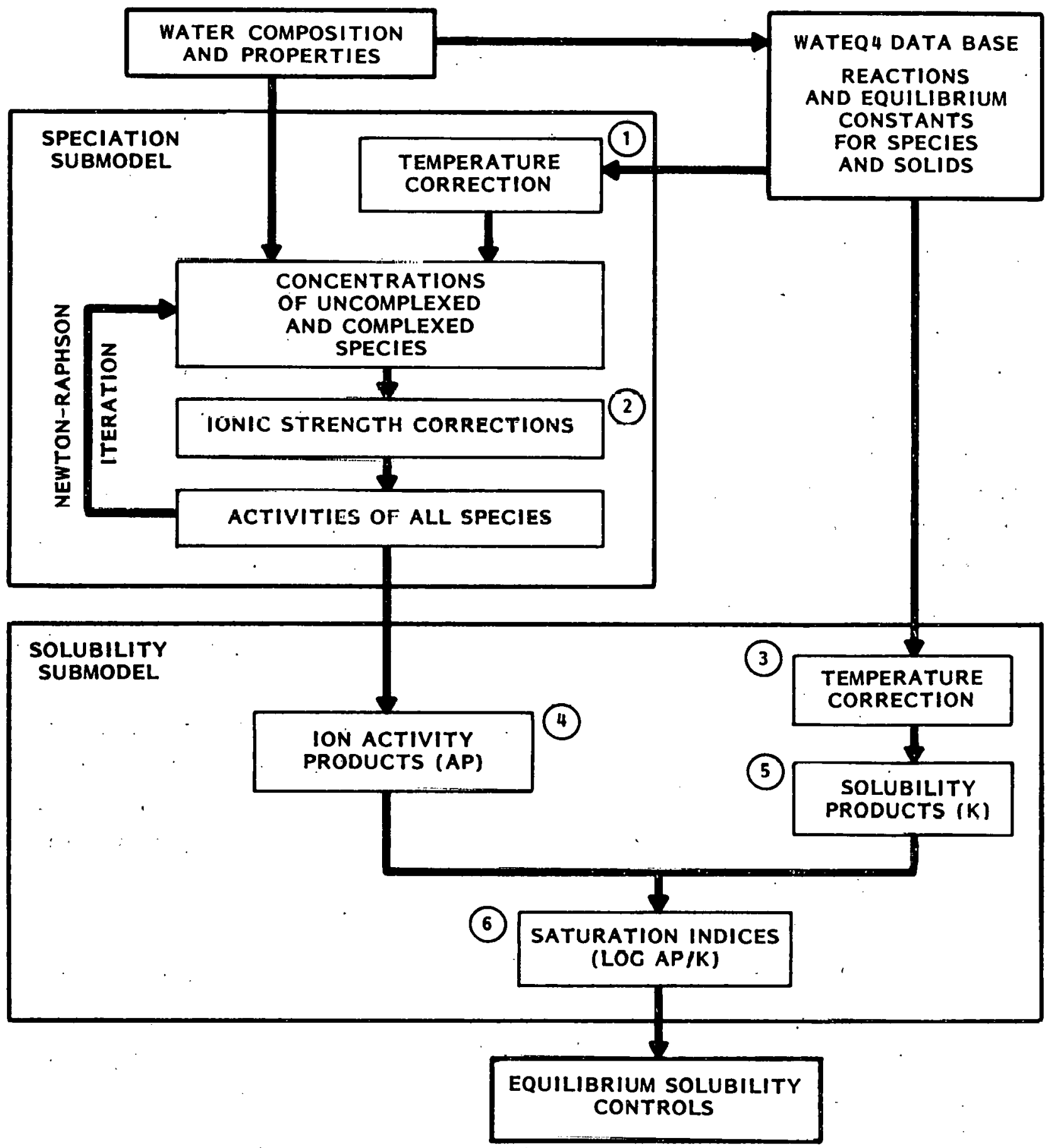

FIGURE 1. Schematic Flow Diagram for Aqueous Speciation and Solubility Submodels of WATEQ4 
parent species(a) are then combined with solubility constants for the solids in the WATEQ4 data base to calculate permissible solubility controls. A primary purpose of this validation study is to check the correctness of these calculated solubility controls against those identified and characterized in the laboratory studies or natural water-rock systems (bottom of Figure 1). The calculation of equilibrium constants $\left(\log \mathrm{K}_{r}^{0}, T\right)$ and their corrections for temperature and ionic strength are described briefly because they are important to an understanding of geochemical modeling and the uranium validation study. The reader familiar with these topics may wish to skip to the subsequent section on thermodynamic data.

\section{CALCULATION OF EQUILIBRIUM CONSTANTS FOR DATA BASE}

Thermodynamic data are stored in the data base and used by the geochemical model in the form of equilibrium constants(b) for complexation and dissolution reactions. Aqueous speciation and mineral solubility are calculated from the equilibrium constants stored in the WATEQ4 data base. The stability constants $\left(\log K_{r, 298}^{0}\right)$ may be calculated using Gibbs free energies of reaction $\left(\Delta G_{r, T}^{0}\right)$ :

$$
\log K_{r, T}^{0}=\frac{-\Delta G_{r, T}^{0}}{2.303 R T}
$$

where $T$ is the temperature in degrees Kelvin $\left(25^{\circ} \mathrm{C}=298 \mathrm{~K}\right)$. A list of symbols (and their definitions), physical constants, and conversion factors is given at the beginning of this report. At $T=298 \mathrm{~K}, \Delta \mathrm{G}_{\mathrm{O}}^{\mathrm{O}}, 298$ is calculat.ed from the Gibbs free energies of formation $\left(\Delta G_{f, 298}^{0}\right)$ as:

(a) The parent species comprise a set of linearly independent aqueous species in terms of which all complexation and dissolution reactions are written.

(b) The equilibrium constants for the aqueous speciation reactions will be referred to in the text as stability constants. The equilibrium constants for the hydrolysis reactions for the minerals will be referred to as solubility products. 


$$
\Delta G_{r, 298}^{0}=\Delta G_{f, 298}^{0}(\text { products })-\Delta G_{f, 298}^{0}(\text { reactants }) .
$$

Because

$$
\Delta G_{f, 298}^{0}=\Delta H_{f, 298}^{0}-298.15 \Delta S_{298}^{0}
$$

(where $\Delta H \&, 298$ and $S 298$ are, respectively, the enthalpy of formation and entropy), Equation (2) can be arranged to:

$$
\begin{aligned}
\Delta G_{r, 298}^{0} & =\Delta H_{f, 298}^{0}(\text { products })-\Delta H_{f, 298}^{0}(\text { reactant } \varepsilon) \\
& -298.16\left[\Delta S_{298}^{0} \text { (products) } \Delta S_{298}^{0} \text { (reactants) }\right] .
\end{aligned}
$$

Values of $\log K_{r}^{0}, T$ may therefore be calculated from $\Delta H_{f, 298}^{0}$ and $S_{298}^{0}$ values, which are based primarily on calorimetric measurements of heats-of-solution and heat capacities, respectively. Values of $\log k_{r}^{0}, T$ may also be determined directly from solubility measurements that have been corrected for aqueous speciation and ionic strength.

CORRECTIONS TO STABILITY CONSTANTS--TEMPERATURE AND IONIC STRENGTH

The laboratory and field data available for the validation study were collected at a variety of temperatures and ionic strengths. The equilibrium constants in the WATEQ4 data base, however, are uniformly for a temperature of $25^{\circ} \mathrm{C}(298 \mathrm{~K})$ and zero ionic strength.

For analytical data at $\mathrm{T} \neq 25^{\circ} \mathrm{C}$, the equilibrium constants are recalculated by the model to the appropriate temperature (Figure 1, Boxes 1 and 3 ) using the van't Hoff relation (Lewis and Randall 1961):

$$
\log K_{r, T}^{0}=\log K_{r, T r}^{0}-\frac{\Delta H_{r, T r}^{0}}{2.303 R}\left[\frac{1}{T}-\frac{1}{T r}\right]
$$


where $\mathrm{Tr}$ is some reference temperature, usually $298 \mathrm{~K}$ and $\Delta \mathrm{H}_{\mathrm{r}, \mathrm{Tr}}^{\mathrm{O}}=\Delta \mathrm{H}_{\mathrm{f}, \mathrm{Tr}}^{\mathrm{O}}$ (products) - $\Delta H_{f}^{O}, \mathrm{Tr}$ (reactants): If $\Delta H_{f}, 298$ values are available for the reaction components, $\Delta H_{r, 298}^{0}$ values are calculated and stored as part of the WATEQ4 data base. For reactions where $\Delta H_{r, 298}^{0}$ values could not be computed because $\Delta H_{f, 298}^{0}$ values are not available, the model assumes that

$$
\log K_{r, T}^{0} \simeq \log K_{r, 298}^{0}
$$

Because the van't Hoff relation assumes that $\Delta H_{r, T}^{O}$ is independent of temperature (i.e., $\Delta C_{P}^{O}=0$ ), this equation provides only an approximation for the change of $\log K_{r, T}^{0}$ with temperature. Therefore, applications of WATEQ4 were limited to temperatures of $\angle 100^{\circ} \mathrm{C}$. Moreover, analytical expressions for $\log K_{r, T}^{0}$ as a function of temperature, stored in earlier versions of WATEQ. (Truesdell and Jones 1974; Ball, Jenne, and Cantrell 1981) for a limited number of aqueous species and solids, have not yet been added to WATEQ4:

Aqueous speciation and mineral solubility are calculated from the activities of the solution constituents that are corrected for ionic strength (Figure 1, Box 2). Activities of individual aqueous species are corrected for ionic strength using the Davies or extended Debye-Huckel equations (Truesdeli and Jones 1974; Ball, Nordstrom, and Jenne 1980). The activities of all solld phases and minerals(a) are considered to be unity. The activity of water is corrected for ionic strength using the approximate relation from Garrels and Christ (1965):

(a) A mineral is defined as "a naturally occurring inorganic element or compound having an orderly internal structure and characteristic chemical composition, crystal form, and physical properties" (Bates and Jackson 1980). This definition therefore excludes amorphous and/or glass-like solids, and certain artificial crystalline solids $\left(\mathrm{e} . \mathrm{g} ., \mathrm{PuO}_{2}\right)$. However, inclusion of these non-mineral phases in the data bank of a geochemical model, as in WATEQ4, is of paramount importance in adequately determining the solubility controls on toxic elements in waters resulting from interaction with the wastes of an industrialized society. 


$$
a_{H_{2} 0}=1.0-0.017 \Sigma . m_{i} \text {, }
$$

where $\Sigma m_{j}$ is the sum of the molalities of all aqueous species.

\section{SOLUBILITY CALCULATIONS}

After the aqueous speciation for a given water is determined, solubilityequilibrium hypotheses are tested. Ion activity products (AP) are calculated from the activities of the parent species, using the stoichiometries of the hydrolysis reactions for minerals and other solids in the WATEQ4 data base (Figure 1, Box 4). These activity products are then compared to the equili= brium solubility products (K) (Figure 1 , Box 5) stored in WATEQ4 for the same solid phases, to test the assumption that some of the dissolved constituents in an aqueous solution or natural water are in equilibrium with certain solids. Saturation indices $(\log A P / K$ ) (Figure 1 , Box 6) are calculated to determine if the water is at thermodynamic equilibrium $(\log A P / K \simeq 0)$, is oversaturated $(\log A P / K>0)$, or is undersaturated $(\log A P / K<0)$ with respect to a certain solid phase. These data make it possible to ascertain permissible equilibrium solubility controls for that water. 
One objective of the uranium validation study was to identify and correct significant deficiencies in the WATEQ4 thermodynamic data base for uranium solutes and solids. The revisions to the uranium data base that have been made are presented in this section. Because natural ground-water samples were included in the validation study, vanadium was added to the thermodynamic data base because of the known existence of uranium-vanadium compounds [e.g., carnotite $\left.\left[\mathrm{K}_{2}\left(\mathrm{UO}_{2}\right)_{2}\left(\mathrm{VO}_{4}\right)_{2}\right]\right]$.

The $\log K_{r, 298}^{0}$ and $\Delta H_{r, 298}^{0}$ values for the aqueous speciation and solubility reactions of uranium in WATEQ4 were primarily from the WATEQ3 data base. The uranium reactions in WATEQ3 (see Table 1) were calculated by Ball, Jenne, and Cantrell (1981) from the uranium thermodynamic data tabulated by Langmuir (1978). Ball, Jenne, and Cantrell (1981, Table 1) noted some apparent discrepancies in the internal consistency of Langmuir's tabulated data. See Appendix $A^{(a)}$ for a discussion of these discrepancies.

\section{REVISIONS TO THE WATEQ4 DATA BASE FOR URANIUM}

Revisions to the thermodynamic data base include recalculation of selected uranium reactions in the WATEQ3 data base, and evaluation of thermodynamic data for hydroxyl complexes of $U(V I)$, including one or more anionic $U(V I)$ species. The $\log \mathrm{K}_{r, 298}^{0}$ and $\Delta \mathrm{H}_{r, 298}^{0}$ for the species $\mathrm{UO}_{2} \mathrm{OH}^{+}$in WATEQ4 were revised using the data in Dongarra and Langmuir (1980). Neutral and anionic hydroxyl complexes of U(VI), which are not included in Langmuir (1978), have been reported in recent reviews (Lemire and Tremaine 1980; Allard, Kipatsi, and Liljenzin 1980). Because the inclusion of species such as $\mathrm{UO}_{2}(\mathrm{OH})_{2}^{\circ}$ and $\left(\mathrm{UO}_{2}\right)_{3}(\mathrm{OH})_{7}$ (Lemire and Tremaine 1980) will have a significant effect on the speciation of dissolved U(VI) under alkaline conditions, the validation of the WATEQ4 geochemical model, via solubility studies, necessitated a re-evaluation of data supporting neutral and anionic hydroxyl U(VI) complexes (Appendix B). Based on new potentiometric titration data, Sylva and Davidson (1979) have proposed a

(a) References cited in all appendices, except Appendix G, are included in the main reference list of this report. 
TABLE 1. Aqueous Species and Solids of Uranium in the Thermodynamic Data Base of WATEQ3 (Ball, Jenne, and Cantrell 1981)

Aqueous Species

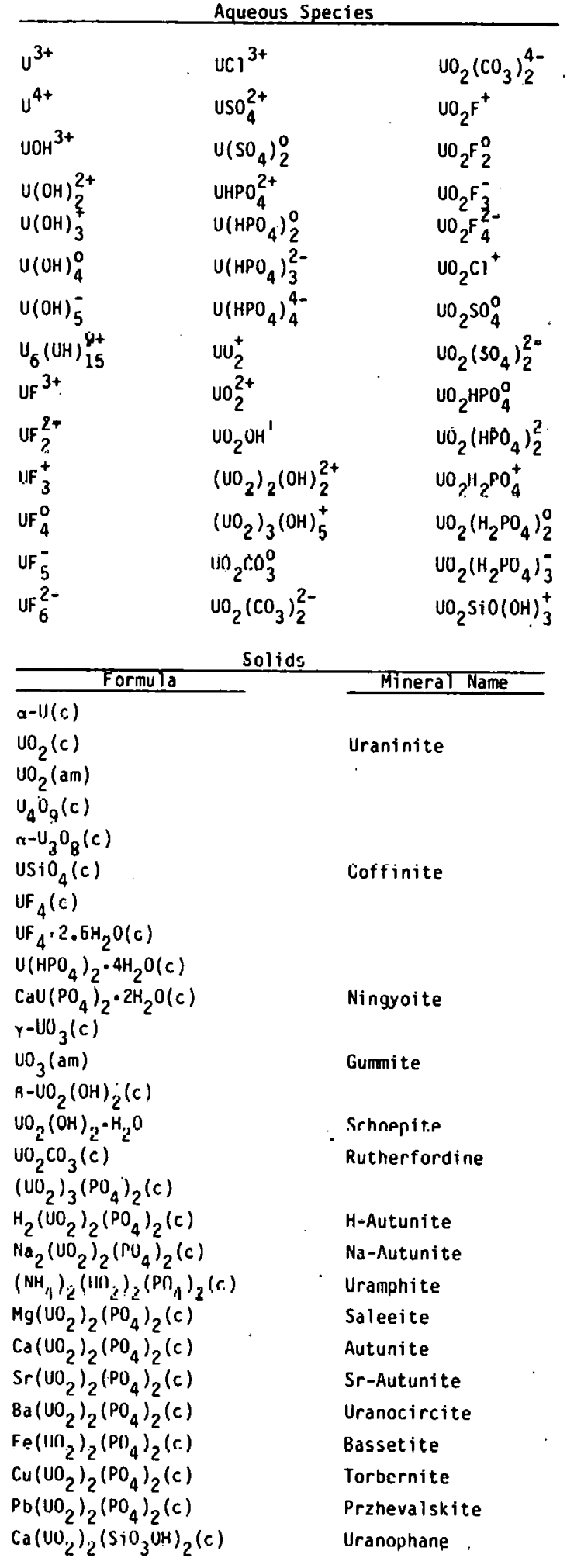


speciation scheme for U(VI) hydroxyl complexes, which is different from that in Langmuir (1978). The speciation scheme of Sylva and Davidson (1979) is briefly described in Appendix $B$. The published literature, however, does not provide a rational basis for selecting among the proposed polynuclear hydroxyl complexes of $U(V I)$.

Tremaine et al. (1981) have reported new solubility data for $\mathrm{UO}_{2}$ (c) (i.e., uraninite) under alkaline conditions. We have used these solubility data to estimate stability constants for the hydroxyl complexes of U(IV) (Appendix $C$ ), as an alternative to those similarly estimated by Langmuir (1978). These two sets of stability constants were used in a sensitivity analysis mode to evaluate the solubility of $\mathrm{UO}_{2}(\mathrm{c})$ under reducing conditions.

Thermodynamic data for the uranium complexes other than hydroxyl were not significantly changed from the data presented in Langmuir (1978) and from the $\log K_{r, 298}^{0}$ values computed by Ball, Jenne, and Cantrell (1981). Because some of the aqueous solutions modeled from laboratory studies contained significant $\mathrm{NO}_{3}$ concentrations, the aqueous complex $\mathrm{UO}_{2}\left(\mathrm{NO}_{3}\right)_{2}^{0}$ (Wagman et al. 1981) was added to WATEQ4. The $\log K_{r}^{0}, 298$ and $\Delta H_{r, 298}^{0}$ values in WATEQ4 for the species $\mathrm{UO}_{2}\left(\mathrm{HPO}_{4}\right)_{2}^{2-}$ were revised using the new cumulative association constant determined by Dongarra and Langmuir (1980) from potentiometric titrations in $\mathrm{Na}_{2} \mathrm{HPO}_{4}-\mathrm{UO}_{2}\left(\mathrm{NO}_{3}\right)_{2}$ solutions. The data for $\mathrm{UO}_{2}\left(\mathrm{HPO}_{4}\right)_{2}^{2-}$ and a brief discussion concerning the validity of the data for the other uranyl phosphate complexes are given in Appendix D. During the course of this validation study, thermodynamic data were identified for the complex $\mathrm{UO}_{2}\left(\mathrm{CO}_{3}\right)_{2}\left(\mathrm{H}_{2} \mathrm{O}\right)_{2}^{2-}($ Mann $1974 a, b)$, which is not in the WATEQ4 data base. From the available data, this hydrated uranyl carbonate complex appears to be chemically equivalent to the species $\mathrm{UO}_{2}\left(\mathrm{CO}_{3}\right)_{2}^{2-}$ (discussed in Appendix $\mathrm{D}$ ), which is already in WATEQ4.

Thermodynamic data for several uranium solids were revised or added to the WATEQ4 data base. The thermodymanic data for coffinite $\left(\right.$ USiO $\left._{4}\right)$ were revised according to the corrections described in Langmuir and Chatham (1980). We have calculated a revised $\Delta H_{f, 298}^{0}$ that is thermodynamically consistent with $\Delta G_{f, 298}^{0}$ and $\mathrm{S}_{298}^{0}$ for $\left(\mathrm{UO}_{2}\right)_{3}\left(\mathrm{PO}_{4}\right)_{2}$. The inconsistency in Langmuir's data for $\left(\mathrm{UO}_{2}\right)_{3}\left(\mathrm{PO}_{4}\right)_{2}(\mathrm{Ball}$, Jenne, and Cantrell 1981) and the calculation of its revised $\Delta H_{f, 298}^{0}$ are described in Appendix $E$. To increase the model's 
competency for calculating solubility controls in solutions with high concentrations of dissolved nitrate, values of $\log \mathrm{K}_{r, 298}^{0}$ and $\Delta \mathrm{H}_{r, 298}^{0}$ were added to WATEQ4 for several uranyl nitrate solids. Thermodynamic data for the solids $\mathrm{UO}_{2}\left(\mathrm{NO}_{3}\right)_{2}, \mathrm{UO}_{2}\left(\mathrm{NO}_{3}\right)_{2} \cdot 2 \mathrm{H}_{2} \mathrm{O}, \mathrm{UO}_{2}\left(\mathrm{NO}_{3}\right)_{2} \cdot 3 \mathrm{H}_{2} \mathrm{O}$, and $\mathrm{UO}_{2}\left(\mathrm{NO}_{3}\right)_{2} \cdot 6 \mathrm{H}_{2} \mathrm{O}$ were taken from NBS Technical Note 270-8 (Wagman et al. 1981). The sources of the thermodynamic data for these U(VI) nitrate solids are described in Cordfunke and 0'Hare (1978). Sodium uranate solids have been identified as solubility controls for dissolved uranium in several laboratory studies (e.g., Wamser et al. 1952; Brush 1980), and may even be solubility controls in natural ground waters (Muto 1965; Brush 1980; Paquette and Lemire 1981). To model these as solubility controls, $\log \mathrm{K}_{r, 298}^{0}$ and $\Delta \mathrm{H}_{r, 298}^{0}$ values for hydrolysis reactions of $\mathrm{Na}_{3} \mathrm{UO}_{4}, \mathrm{Na}_{2} \mathrm{UO}_{4}$, and $\mathrm{Na}_{2} \mathrm{U}_{2} \mathrm{O}_{7}$ were added to the WATEQ4 data base. These calculations"and the sources of the thermodynamic data are given in Appendix F.

The solubilities of the mineral schoepite $\left[\mathrm{UO}_{3} \cdot 2 \mathrm{H}_{2} \mathrm{O}\right.$ or $\left.\mathrm{UO}_{2}(\mathrm{OH})_{2} \cdot \mathrm{H}_{2} \mathrm{O}\right]$ and the solid $\mathrm{UO}_{2}(\mathrm{OH})_{2}$ are particularly important to the validation study because these solids were often identified as solubility controls for uranium in laboratory studies. The thermodynamic constants for these two solids in WATEQ4 (from Langmuir 1978) differ by approximately 300 cal from those in Lemire and Tremaine (1980). These differences center around acceptance of the solubility measurements for $\mathrm{UO}_{2}(\mathrm{OH})_{2}$ at $25^{\circ} \mathrm{C}$ obtained by Gayer and Leider (1955). (a) Langmuir (1978) bases his derivation of thermodynamic data for schoepite and $\mathrm{UO}_{2}(\mathrm{OH})_{2}$ on the assumption that Gayer and Leider (1955) measured the $\log \mathrm{K}_{r, 298}^{0}$ for the dissolution of $\mathrm{B}_{-}-\mathrm{UO}_{2}(\mathrm{OH})_{2}{ }^{(\mathrm{b})}$ at $25^{\circ} \mathrm{C}$. Because schoepite $\left[\mathrm{UO}_{2}(\mathrm{OH})_{2} \cdot \mathrm{H}_{2} \mathrm{O}\right.$

(a) Gayer and Leider (1955) and Wagman et al. (1981) use the formula $\mathrm{UO}_{3} \cdot \mathrm{H}_{2} \mathrm{O}$ which is chemically equivalent to $\mathrm{UO}_{2}(011) \%$.

(b) The polymorphism of $\mathrm{UO}_{2}\left(\mathrm{OH}_{2}\right)$ has been summarized by Brush (1980). Gayn $\mathrm{r}$ and Leider (1955), however, provide no crystal structure data to identify the polymorphic form of their $\mathrm{UO}_{2}(\mathrm{OH})_{2}$ solid. Wagman et al. (1981) and Cordfunke and $0^{\prime}$ Hare (1978) tabuTate $\Delta H_{f}^{0}, 298$ values for three polymorphic forms $(\beta, \varepsilon, \alpha)$ of $\mathrm{UO}_{2}(\mathrm{OH})_{2}$. Entropy data are only given for $\beta-\mathrm{UO}_{2}(\mathrm{OH})_{2}$. The $\beta$-form inverts to the $\alpha$-form at $5{ }^{\circ} \mathrm{C}$ with an enthalpy of transition of $1.35 \mathrm{kcal} \mathrm{mol}{ }^{-1}$. The $\varepsilon$-forms recrystallizes to $\mathrm{B}_{-} \mathrm{UO}_{2}(\mathrm{OH})_{2}$ when heated in air above $120^{\circ} \mathrm{C}$ with the difference in $\Delta H_{f}^{0} 298$ values for the $\beta$ - and $\varepsilon$-forms being only $600 \mathrm{cal}$ (Cordfunke and ofhare 1978). Although the phase relations between these polymorphs are not well known, exclusion of $\alpha$ and $\varepsilon$-forms of $\mathrm{UO}_{2}(\mathrm{OH})_{2}$ from the data base of a geochemical model should not significantly affect solubility calculations for $U(V I)$. 
or $\mathrm{UO}_{3} \cdot 2 \mathrm{H}_{2} \mathrm{O}$ ] is stable with respect to the solid $\mathrm{UO}_{2}(\mathrm{OH})_{2}$ at $\left\langle 60^{\circ} \mathrm{C}\right.$ (Robins 1966), Lemire and Tremaine (1980) accepted the contention of Naumov, Ryznenko, and Knodakovsky (1974) that Gayer and Leider (1955) had, in fact, measured the dissolution of schoepite in their experiments at $25^{\circ} \mathrm{C}$.

Gayer and Leider (1955) prepared pure $\mathrm{UO}_{2}(\mathrm{OH})_{2}$ by prolonged boiling (thus $\mathrm{T}>60^{\circ} \mathrm{C}$ ) of an uranyl acetate solution. Based on ignition to $\mathrm{U}_{3} 0_{8}$, Gayer and Leider (1955) determined that the uranium content of their $\mathrm{UO}_{2}(\mathrm{OH})_{2}$ samples to be $78.2 \mathrm{wt} \%$. The uranium content of ideal $\mathrm{UO}_{2}(\mathrm{OH})_{2}$, schoepite $\left(\mathrm{UO}_{3} \cdot 2 \mathrm{H}_{2} \mathrm{O}\right)$, and $\mathrm{U}_{3} \mathrm{O}_{8}$ are $78.29,73.91$, and $84.80 \mathrm{wt}$, respectively. Therefore, although Gayer and Leider (1955) used $\mathrm{UO}_{2}(\mathrm{OH})_{2}$ as a starting material, phase relations for uranyl nydroxides (Robins 1966) suggest that the solubility equilibrium determined by Gayer and Leider was actually that of schoepite.

SOLUTION SPECIES, COMPLEXES, AND SOLIUS OF VANADIUM

The uranyl vanadate minerals carnotite $\left[\mathrm{K}_{2}\left(\mathrm{UO}_{2}\right)_{2}\left(\mathrm{VO}_{4}\right)_{2}\right]$ and tyuyamunite [Ca $\left.\left(\mathrm{UO}_{2}\right)_{2}\left(\mathrm{VO}_{4}\right)_{2}\right]$ are known to occur naturally and are potential solubility controls for dissolved uranium in natural waters. Computation of the activity products for the nydrolysis reactions for these two minerals thus requires a prior calculation of the aqueous speciation of dissolved vanadium. Therefore, adding $\log K_{r, 298}^{0}$ and $\Delta H_{r, 298}^{0}$ values for the aqueous speciation reactions of vanadium to WATEQ4 was necessary to competently model uranium solubility in ground waters.

The thermodynamic data for aqueous complexes and solids of vanadium have been recently reviewed and compiled.(a) The reactions and thermodynamic data added to WATEQ4 included those for the aqueous complexes and solids for the valence states $V(I I I), V(I V)$, and $V(V)$. The solution species for vanadium consisted of the complexes with $\mathrm{OH}^{-}, \mathrm{F}^{-}, \mathrm{SO}_{4}^{2-}, \mathrm{Cl}^{-}$, and $\mathrm{NO}_{3}^{-}$. Data were not found for vanadium complexes with dissolved carbonate or dissolved phosphate. In addition to the uranyl vanadate minerals carnotite and tyuyamunite, other solids added to the WATEQ4 data base include vanadium oxides, hydroxides,

(a) Schwab, A. P., and K. M. Krupka. (In preparation.) Thermodynamic Data for Vanadium and Selected Revisions for Uranium. PNL Report. Pacific Northwest Laboratory, Richland, Washington. 
halides, phosphates, sulfates, and nitrates. Several solid phases that contained vanadium and a second cation (e.g., $\left.\mathrm{Mg}_{2} \mathrm{~V}_{2} \mathrm{O}_{7}\right)$ were also included in the data base. Sources of published thermodynamic data included CODATA (1976); Baes and Mesmer (1976); Cnase et al. (1975); Naumov, Ryznenko, and Knodakovsky (1974); Parker, Wagman, and Evans (1971); Robie, Hemingway, and Fisher (1978); Smith and Martell (1976); and Wagman et al. (1968, 1969, 1981). 


\section{PUBLISHED LABORATORY SOLUBILITY AND GROUND-WATER DATA}

Solution analyses from published laboratory investigations were used for the initial stages of the validation study because such studies generally involve chemical systems (aqueous solutions and solids) that are composed of only a few components, and hence, have the potential for being chemically well characterized. Ground-water analyses from published field studies were also modeled to partially validate WATEQ4 with respect to natural aqueous systems. The results of the uranium validation study are summarized in the subsequent section on uranium mineral equilibria.

\section{LABORATORY STUDIES}

A literature search was conducted to identify laboratory studies that involved the precipitation and/or dissolution of uranium-bearing solids. Included in the search were studies on the solubilities of uranium solids, speciation of dissolved uranium, adsorption of uranium on inorganic solids, leaching of nuclear fuel and waste-form materials, and in situ uranium mining. The studies were evaluated according to their adequacy for geochemical modeling. The primary selection criteria were (in order of priority): 1) a uranium-bearing solid had to have been physically identified as contributing to the chemistry of the experimental aqueous system; and 2) analytical analyses had to include, at a minimum, total dissolved uranium, $\mathrm{pH}, \mathrm{EH}^{\mathrm{H}}$, and temperature. Values of $\mathrm{EH}^{\mathrm{H}}$ were usually estimated for laboratory solutions. Approximately $60 \%$ of the examined studies failed these criteria. (a)

Solution analyses from lahnratory studies by Brush (1980), Chukhlantsev and Stepanov (1956), Gayer and Leider (1955), Miller (1958), Moskvin, Shelyakina, and Perminov (1967), Muto (1965), Robins (1966), Sergeyeva et al. (1972), and Wamser et al. (1952) were used for this study. Brief descriptions of these laboratory studies and the solution analyses that were modeled in the uranium validation study are given in Appendix $H$. The selected solution

(a) Because the reviewed studies may be of value to readers by reducing review time in further uranium validation studies, references rejected for this validation study are included in Appendix G. 
analyses were assumed to represent equilibrium conditions in these solubility studies. We have documented (Appendix $H$ ) all efforts by these investigators [e.g., Brush (1980) and Muto (1965)] to demonstrate that they had attained solubility equilibrium. On the other hand, some uranium studies (Appendix,G) were rejected because the nature of the experiments and/or analytical data did not represent equilibrium conditions. At this time, we do not feel that kinetic considerations play a dominant role in interpreting the modeling results for the laboratory studies used in the uranium validation study.

Most of the laboratory studies, however, do not report $E^{H}$ values for the solution analyses. Because most of the reviewed studies dealt with the solubility of $U(V I)$ solids and màde no attempt to attaln reducing conditions, a lack of reported $\mathrm{F}^{\mathrm{H}}$ values for these studies is not critical because they would generally be saturated with oxygen. However, as a useful guide to selecting initial $E^{H}$ values for modeling, $p E$ values were calculated using the empirical relationship:

$$
\mathrm{pE}+\mathrm{pH}=13.6
$$

at the specified $\mathrm{pH}$ of each solution. The above $\mathrm{pE}+\mathrm{pH}$ relationship was calculated from $E^{H}$ and $\mathrm{pH}$ values for the zone of aqueous environments in contact with atmospheric oxygen (e.g., mine waters, rain, streams, ocean water, and aerated saline residues) shown in Garrels and Christ (1965, Figure 11.2). Equation (7) also corresponds closely to $\mathrm{pE}+\mathrm{pH}$ relationships determined for soil suspensions left open to the atmosphere (Lindsay 1979). Values of $p E$ were converted to $E^{H}$ values by the equation:

$$
\mathrm{E}^{\mathrm{H}}=\frac{? .3013 \mathrm{RT}}{\mathrm{F}} \mathrm{pE}
$$

where $T$ is in degrees Kelvin.

Several laboratory solutions containing dissolved U(VI) complexes were also modeled with $E^{H}$ values set by the maximum oxidation boundary for the stability of water, 


$$
\mathrm{H}^{+}+\mathrm{e}^{-}+0.5 \mathrm{O}_{2}(\mathrm{~g})=\mathrm{H}_{2} \mathrm{O} \text {. }
$$

For a $1-\mathrm{atm}$ pressure of $\mathrm{O}_{2}(\mathrm{~g})$ at $25^{\circ} \mathrm{C}$,

$$
p E+p H=20.78
$$

for the $\mathrm{H}_{2} \mathrm{O} / \mathrm{O}_{2}(\mathrm{~g})$-equilibrium. No differences, however, were observed in the speciation of dissolved uranium, as calculated by WATEQ4, using the $\mathrm{pE}+\mathrm{pH}$ Equations (7) or $(10)$. The $E^{H}$ values used to model laboratory solubility studies. of U(IV) solids will be described on an individual basis. Although the activity of electrons is so low in aqueous solutions that $\mathrm{pE}$ has little physical significance (Thorstenson 1982), pE remains a useful computational device.

\section{FIELD STUDIES}

Two published ground-water studies were identified for use in the uranium validation study. These investigations include the related papers of Chatham, Wanty, and Langmuir (1981) and Wanty, Langmuir, and Chatham (1981), and a paper by Păces (1969). The critical aspect of these studies was that the water analyses included analytical measurements of $\mathrm{pH}, \mathrm{E}^{\mathrm{H}}$, and temperature, as well as the concentrations of the important dissolved constituents (including uranium). Although the uranium mineralization was not determined at the exact site of the water samples, the waters were from sites having known deposits of uraninite $\left(\mathrm{UO}_{2}\right)$. Appendix $\mathrm{H}$ contains descriptions of these field studies and the ground-water data, that were modeled in the uranium validation study. The results of modeling solubility controls for uranium in these ground waters are summarized in the subsequent section on uranium mineral equilibria. 
URANIUM MINERAL EQUILIBRIA

Saturation indices $(\log A P / K)$ were calculated with WATEQ4 for the uranium minerals and solids stored in the model's data base, using the water analyses selected from the previously described laboratory and field studies. Permissible equilibrium solubility controls for uranium were determined from tne calculated saturation indices (tabulated in Appendix $H$ ), and compared to tnose solids identified in the laboratory and field studies. In previous modeling studies, Jenne et al. (1980) observed that the variance in saturation indices about the zero value for waters in apparent equilibrium with a solid increases with the magnitude of the solubility value for that solid. Jenie et al. (1980) determined that a value of $1 / 20$ th of the $\log$ of the solid's solubility product $\left( \pm 1 / 20 \times \log K_{r, T}^{0}\right)$ represented a useful error band for permissive equilibrium with the solid. All plots of saturation indices which follow in this paper indicate this error band by a dashed line on each side of the equilibrium line $(\log A P / K=0)$ - see Figure 2, for example.

\section{U(VI) HYDROXIDES}

The uranyl hydroxides $\mathrm{UO}_{2}(\mathrm{OH})_{2}$ and $\mathrm{UO}_{2}(\mathrm{OH})_{2} \cdot \mathrm{H}_{2} \mathrm{O}$ (schoepite) were identified as solubility controls for uraniuil in several laboratory investigations used for this validation study. The solid $\mathrm{VO}_{2}(\mathrm{OH})_{2}$ was identified as a precipitate in the selected experiments of Brush (1980)(d) and in those at 65 and $100^{\circ} \mathrm{C}$ of Robins (196\%). The solubility of $\mathrm{UO}_{2}(\mathrm{OH})$ ? was determined primarily from dissolution experiments by Gayer and Leider (1955). The saturation indices calculated for $\mathrm{UO}_{2}(\mathrm{OH})_{2}\left[{ }^{\prime} \mathrm{B}-\mathrm{UO}_{2}(\mathrm{OH})_{2}\right.$ ' in Langmuir (1978)] from these solution analyses are plotted in Figure 2 as a function of the log of the total concentration of dissolved uranium. The error band $( \pm U .27)$ In Figure 2 was computed from $\log \mathrm{K}_{r}^{0}, T$ for the dissolution of $\mathrm{UO}_{2}(\mathrm{OH})_{2}$ at $25^{\circ} \mathrm{C}$, which is the temperature for the solubility experiments of Gayer and Leider (1955).

(a) Brush (1980) identified $\alpha-\mathrm{UO}_{2}(\mathrm{OH})_{2}$ as the polymorphic form of $U(V I)$ nydroxide precipitate in his experiments. 


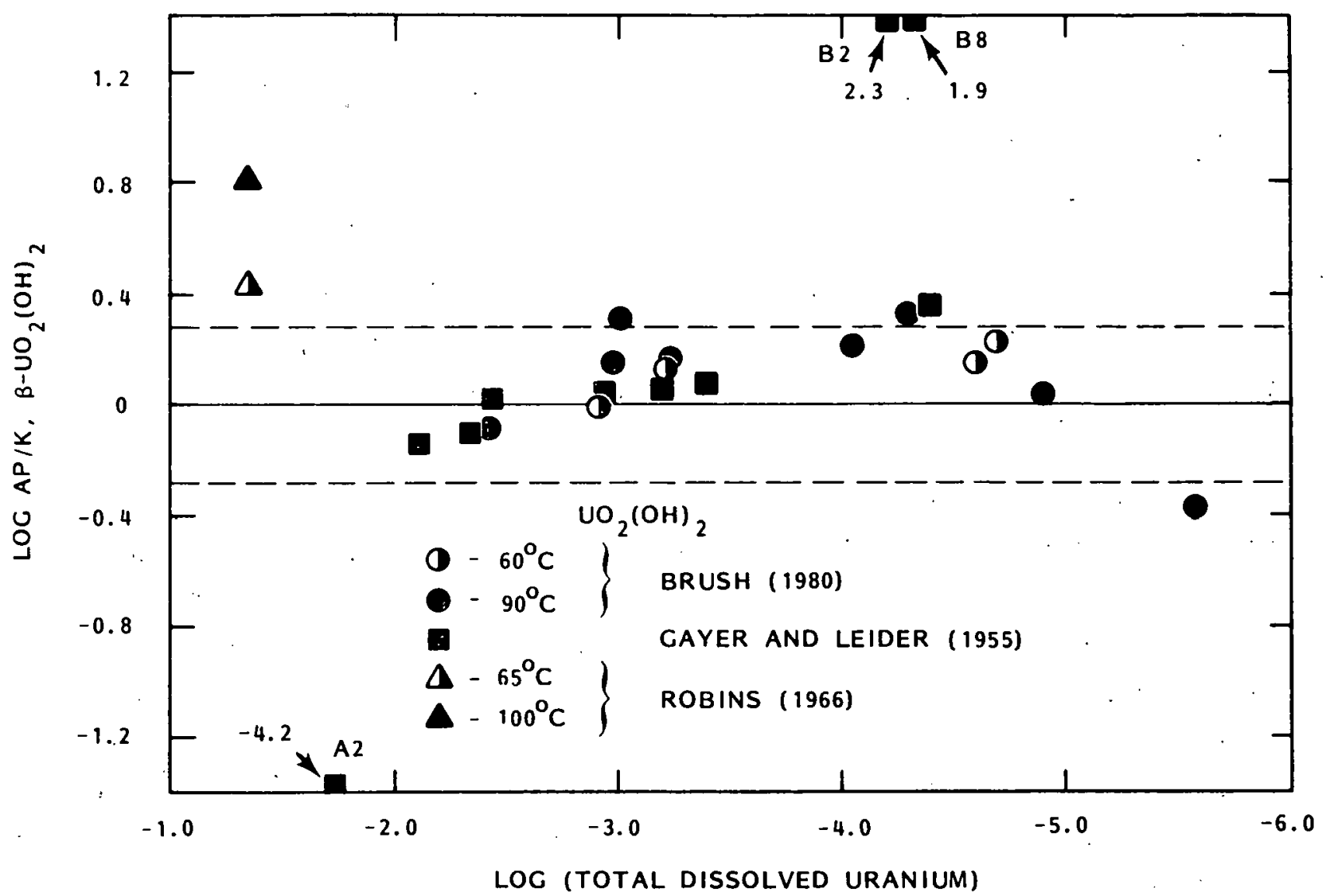

FIGURE 2. $\quad \mathrm{UO}_{2}(\mathrm{OH})_{2}$ Saturation Indices Plotted Versus Log of Tgtal Concentration of Dissolved Uranium [Note that $\log \mathrm{K}_{r}^{\mathrm{C}} \mathrm{T}$ values used to calculate saturation indices in this and subsequent figures in this report have been corrected for temperature. Data from Robins (1966) were modeled using the initial uranium concentrations.]

Except for the saturation indices calculated for three solution analyses from Gayer and Leider (1955) (points indicated as off scale in Figure 2), the calculated indices indicate that $\mathrm{UO}_{2}(\mathrm{OH})_{2}$ is a permissible solubility control for uranium in these solutions. These results, which are based on modeling solutions in which the uranium concentration varies over approximately five orders of magnitude, are in excellent agreement with the experimental results of Brush (1980), Gayer and Leider (1955), and Robins (1966). Although the saturation indices (Table H.8) snow that the two solutions from Robins (1966) are oversaturated $(\log A P / K>0.27)$ with respect to $\mathrm{UO}_{2}(\mathrm{OH})_{2}$, the solution analyses taken from Robins (1966) contained only the initial and not the final 
concentrations of disșolved uranium. The starting solutions used by Robins (1966) all contained $0.05 \mathrm{~m}$ uranyl nitrate. Because Robins (1966) identified $\mathrm{UO}_{2}(\mathrm{OH})_{2}$ as a precipitate in the solutions heated to 65 and $100^{\circ} \mathrm{C}$, the saturation indices computed from the initial uranium concentration should therefore indicate that these solutions are at equilibrium or oversaturated with respect to $\mathrm{UO}_{2}(\mathrm{OH})_{2}$. The increased oversaturation of the $100^{\circ} \mathrm{C}$ solution from Robins (1966) with respect to $\mathrm{UO}_{2}(\mathrm{OH})_{2}$ reflects the decrease of $\log \mathrm{K}_{r, T}^{0}$ with increasing temperature for the dissolution of $\mathrm{UO}_{2}(\mathrm{OH})_{2}$, as calculated by the van't. Hoff relation.

The saturation indices for $\mathrm{UO}_{2}(\mathrm{OH})_{2}$ (Table $\mathrm{H} .1$ ) that were calculated for the aqueous solutions selected from Brush (1980) are also in good agreement with Brush's identification of $\mathrm{UO}_{2}(\mathrm{OH})_{2}$ as a solubility control for uranium in his experiments. Three saturation indices (Figure 2) based on the solution data of Brush (1980) fall on or just outside of the error band for a permissible equilibrium solubility control. Although these three values are still in agreement with the other saturation.indices, the modeling-results may indicate that the $\mathrm{pH}$ values and/or concentrations of uranium reported by Brush (1980) are somewhat inaccurate.

Except for three saturation indices that are indicated as being off scale in Figure 2, the modeling results (Table H.3) are also in good agreement with the solubility measurements for $\mathrm{UO}_{2}(\mathrm{OH})_{2}$ by Gayer and Leider (1955). Modeling of the solution compositions from Gayer and Leider (1955), however, tests only certain aspects of the model because the $\log \mathrm{K}_{r}^{\mathrm{O}}, 298$ for $\mathrm{UO}_{2}(\mathrm{OH})_{2}$ in the model's data base was calculated from $\Delta G_{f, 298}^{O}$ for $\mathrm{UO}_{2}(\mathrm{OH})_{2}$, which itself was derived by Langmuir.(1978) and Baes and Mesmer (1976) from the solubility data of Gayer and Leider (1955). The agreement between the modeling results and solubility experiments for $\mathrm{UO}_{2}(\mathrm{OH})_{2}$ does indicate that the computer coding, the speciation reactions, and ionic strength corrections in WATEQ4 are adequate to reproduce the solubility data over the ranges of $\mathrm{pH}$ values (4 to 5.2 ) and uranium concentrations reported by Gayer and Leider (1955).

However, the saturation indices calculated from three solution analyses from Gayer and Leider (1955) (Nos. B2, B8, and A2 in Table H.3 of this report) fall considerably outside the error band for solubility equilibrium with 
respect to $\mathrm{UO}_{2}(\mathrm{OH})_{2}\left[{ }^{\prime} \mathrm{B}-\mathrm{UO}_{2}(\mathrm{OH})_{2}\right.$ ' in Langmuir (1978)]. These solutions, as well as those with values of the $\log$ of the uranium concentration and $\log A P / K$, respectively, of -4.40 and 0.36 (No. B1 in Table H.3), were calculated by estimating the $\mathrm{pH}$ values for the final solutions from the initial concentrations of perchloric acid and sodium hydroxide solutions. Considerable error could be introduced by this estimation. Solutions $A 2$ and $B 2$ were remodeled over a range of $\mathrm{pH}$ values to calculate the $\mathrm{pH}$ value at which the uranium concentration reported for these solutions by Gayer and Leider (1955) is in equilibrium with $\mathrm{UO}_{2}(\mathrm{OH})_{2}$. For solution $\mathrm{A2}$, which had an estimated initial $\mathrm{pH}$ of 1.7 , the calculated $\mathrm{pH}$ for solubility equilibrium with $\mathrm{UO}_{2}(\mathrm{OH})_{2}$ is 4.0 . This increase in solution $\mathrm{pH}$, as solubility equilibrium is approached, is consistent with the solubility of uranyl hydroxides in acidic solutions. Because $U 0_{2}^{2+}$ is the dominant aqueous species for $U(V I)$ in oxidizing acidic solutions free of complexing ligands (e.g., carbonate and phosphate), the dissolution of $\mathrm{UO}_{2}(\mathrm{OH})_{2}$ (and schoepite) should result in a consumption of $\mathrm{H}^{+}$. For solution B2, which had an estimated initial pH of 11.6 , the calculated $\mathrm{pH}$ for solubility equilibrium with $\mathrm{UO}_{2}(\mathrm{OH})_{2}$ is 6.1 . Because the starting solution for B2 was a $0.0045 \mathrm{~m}$ solution of sodium hydroxide, the decrease of approxiinately six pH units from basic to acidic conditions required for equilibrium with respect to $\mathrm{UO}_{2}(\mathrm{OH})_{2}$ is not reasonable.

Therefore, these discordant results for solution B2: (and similarly for B8) may indicate that: 1) the uranium concentrations reported for B2 and B8 by Gayer and Leider (1955) are incorrect, 2) $\mathrm{UO}_{2}(\mathrm{OH})_{2}$ is not the equilibrium solubility control for solutions $B 2$ and $B 8$, and/or 3) the speciation reactions in the WATEQ4 data base are inadequate for the hydrolysis of $U(V I)$ at high $p H$ values. Because Gayer and Leider (1955) took precautions to exclude $\mathrm{CO}_{2}$ from their solutions (see description of study in Appendix $H$ ), carbonate complexation of dissolved $U(V I)$ was not considered as a source of error for solutions B2 and B8. Although no way exists of confirming the uranium concentrations reported for solutions $B 2$ and $B 8$, these uranium values are consistent with the other concentrations determined by Gayer and Leider (1955, Table I) for the solubility of $\mathrm{UO}_{2}(\mathrm{OH})_{2}$ in sodium hydroxide solutions. Baes and Mesmer (1976, p. 179) mention that the dissolution of $\mathrm{UO}_{2}(\mathrm{OH})_{2} \cdot \mathrm{H}_{2} \mathrm{O}$ is incongruent in neutral and basic solutions and results in the formation of uranate compounds. 
This same behavior can be expected for the dissolution of $\mathrm{UO}_{2}(\mathrm{OH})_{2}$. Gayer and Leider (1955, p. 1448) state that the chemical analyses of the solids resulting from the sodium hydroxide solutions contained some "associated sodium." Although these solids were not analyzed by $X$-ray diffraction, these data are consistent with the formation of sodium uranates (Wamser et al. 1952; Brush 1980) as a solubility control for these basic U(VI) solutions. The formation of sodium uranates in the solubility studies used in the uranium validation will be discussed later.

The calculated oversaturation with respect to $\mathrm{UO}_{2}(\mathrm{OH})_{2}$ for solutions $\mathrm{B} 2$ and B8 could also be due to the omission of one or more U(VI) hydroxyl complexes in the WATEQ4 data base for the speciation of uranium in high $\mathrm{pH}$ solutions. Based on the thermodynamic data for U(VI) species in Langmuir (1978), the dominant hydroxyl complex in solutions B2 and B8 is the polynuclear species $\left(\mathrm{UO}_{2}\right)_{3}(\mathrm{OH})_{5}^{+}$. Lemire and Tremaine (1980), however, have also included thermodynamic data for the hydroxyl complexes $\mathrm{UO}_{2}(\mathrm{OH})_{2}^{0}$ and $\left(\mathrm{UO}_{2}\right)_{3}(\mathrm{OH}) \overline{7}$ [see discussion of U(VI) hydroxyl complexes in Appendix B]. As will be shown by a sensitivity analysis for solubility calculations with schoepite in a later section, inclusion of the neutral and anionic U(VI) hydroxyl complexes will have a profound affect on the solubility calculations for $U(V I)$ at $\mathrm{pH}$ values greater than 7. The saturation indices calculated by WATEQ4 for $\mathrm{UO}_{2}(\mathrm{OH})_{2}$ from solution analyses selected from Brush (1980), Gayer and Leider (1955), and Robins (1966) are plotted in Figure 3 as a function of pH. Unfortunately, except for three solutions from Gayer and Leider (1955), the pH values for the modeled solutions, in which $\mathrm{UO}_{2}(\mathrm{OH})_{2}$ was identitied as a solubllity control, were between 3 and 7 . Therefore, the published solubility studies involving $\mathrm{UO}_{2}(\mathrm{OH})_{2}$ in basic solutions free of complexing ligands such as carbonate, are insufficient to confirm the existence of additional hydroxyl complexes for $\mathrm{U}(\mathrm{VI})\left[\mathrm{e} . \mathrm{g} ., \mathrm{UO}_{2}(\mathrm{OH})_{2}^{\circ}\right.$ and $\left.\left(\mathrm{UO}_{2}\right)_{3}(\mathrm{OH})_{\overline{7}}\right]$.

The mineral schoepite $\left[\mathrm{UO}_{2}(\mathrm{OH})_{2} \cdot \mathrm{H}_{2} \mathrm{O}\right]$ was identified as a solubility control in some of the solutions selected from Miller (1958) and in the 25 and $50^{\circ} \mathrm{C}$ precipitation experiments from Robins (1966). The saturation indices calculated for schoepite from the solution analyses taken from Miller (1958) and Robins (1966) are plotted in Figure 4 as a function of $\mathrm{pH}$. The error band 


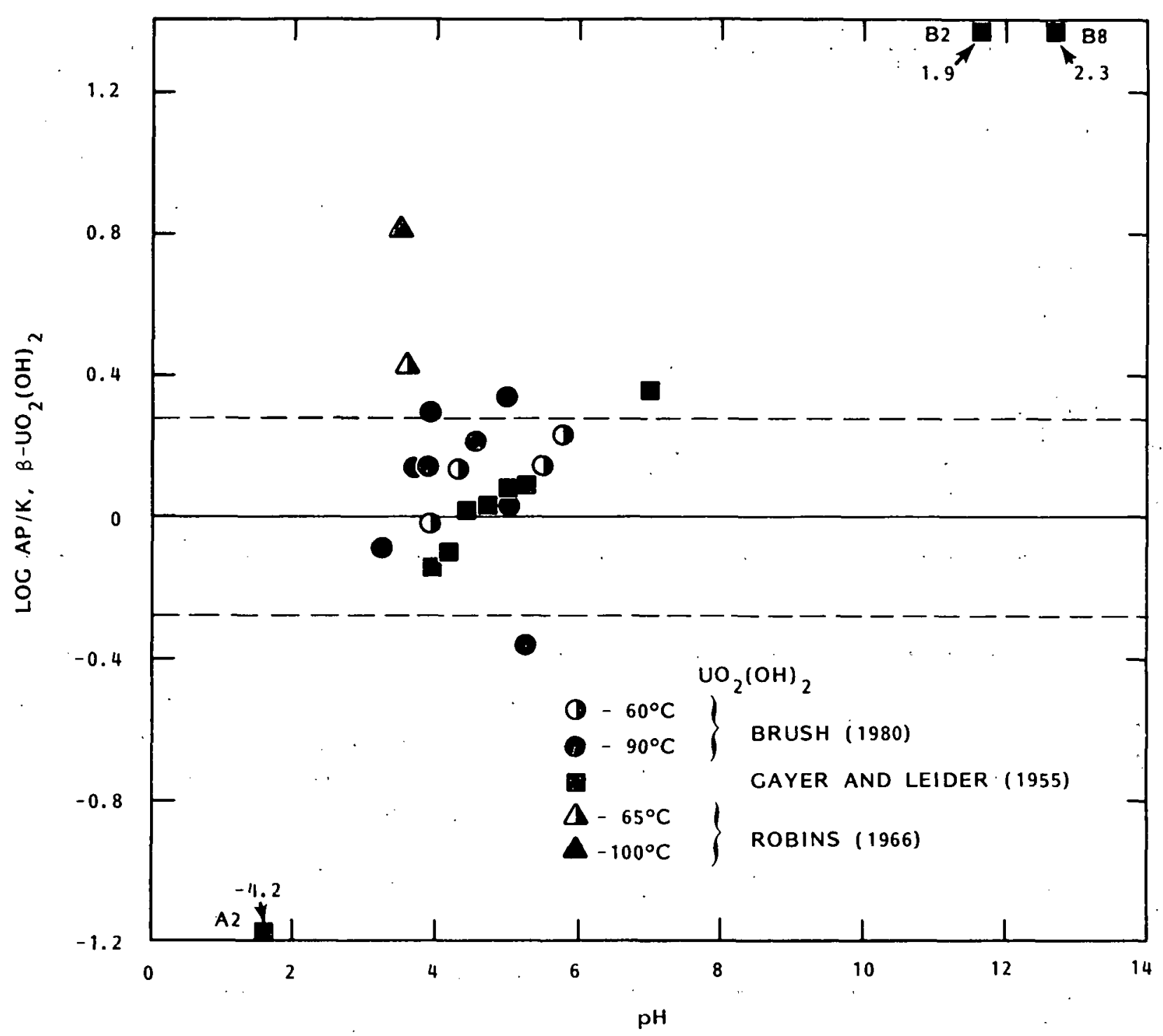

FIGURE 3. $\mathrm{UO}_{2}(\mathrm{OH})_{2}$ Saturation Indices Plotted Versus $\mathrm{pH}$ [Note that data from Robins (1966) were modeled using the initial uranium concentrations.]

$( \pm 0.27)$ in Figure 4 is based on the $\log K_{r}^{0}, T$ for the dissolution of schoepite at $25^{\circ} \mathrm{C}$. Because the phase-stability relations determined for U(VI) hydroxides by Robins (1966) indicate that Gayer and. Leider (1955) may have measured the solubility of schoepite $\left[\mathrm{UO}_{2}(\mathrm{OH})_{2} \cdot \mathrm{H}_{2} \mathrm{O}\right]$ and not $\mathrm{UO}_{2}\left(\mathrm{OH}_{2}\right.$, the saturation indices for schoepite in the solutions from Gayer and Leider (19.55) are also included in Figure 4. The saturation indices calculated for $\mathrm{UO}_{2}(\mathrm{OH})_{2}$ (Figure 3) and 


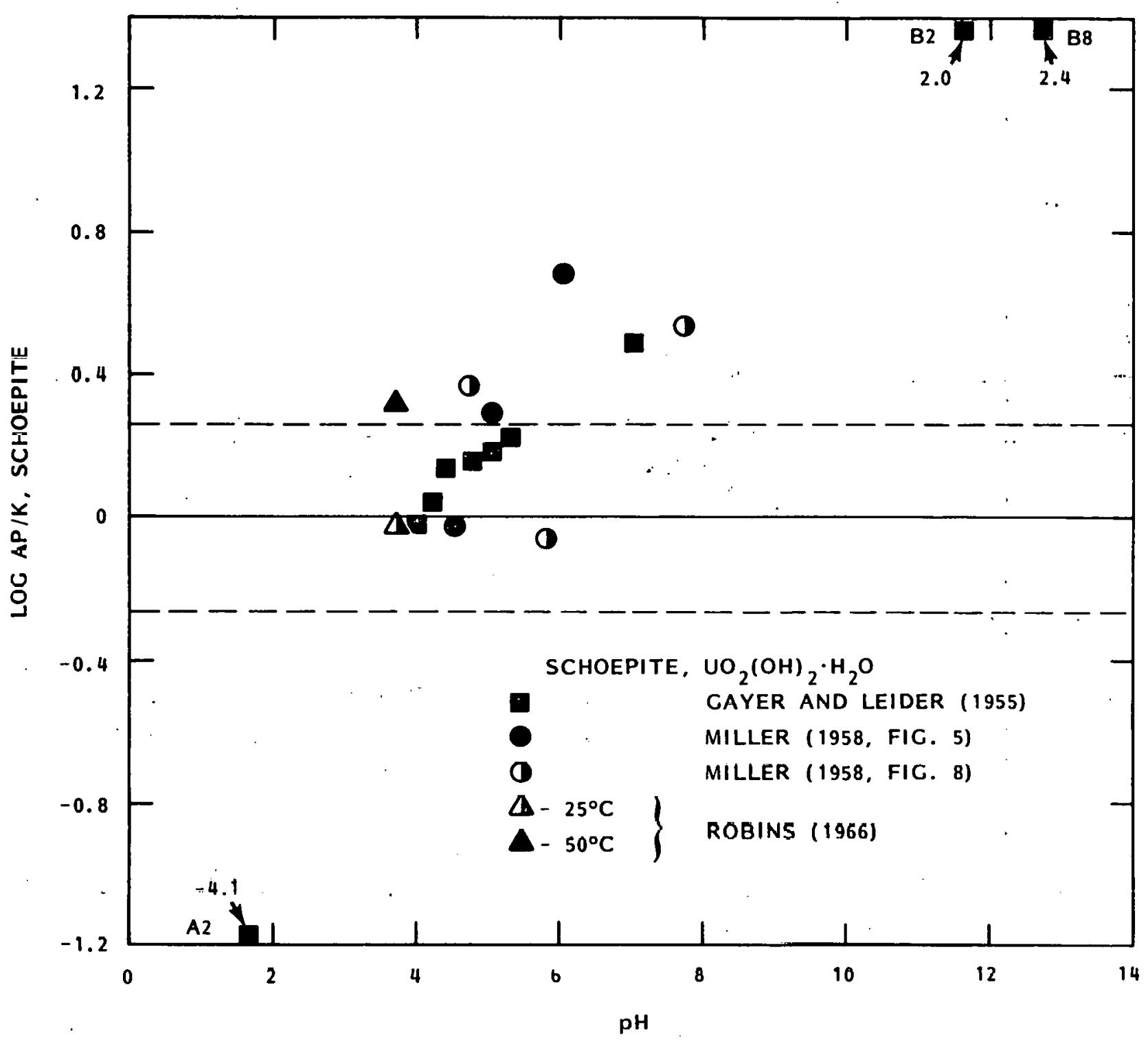

FIGURE 4. Schoepite $\left[\mathrm{UO}_{2}(\mathrm{OH})_{2} \cdot \mathrm{H}_{2} \mathrm{O}\right]$ Saturation Indices Plotted versus pH [Note that the data from Robins (1966) and Miller (1958, Figure 5) were modeled using the initial uranium concentrations.]

schoepite (Figure 4) using the solution analyses from Gayer and Leider (1955) are essentially identical because the $\log \mathrm{K}_{r, 298}^{0}$ values in WATEQ4 for the dissolution of $\mathrm{UO}_{2}(\mathrm{UH})_{2}$ and schoepite are 5.544 and 5.404, respectively (Ball, Jenne, and Cantrell 1981). 
The saturation indices in Figure 4 again indicate that the majority of the published solubility. data for $U(V I)$ hydroxides are restricted to $\mathrm{pH}$ values between 3 and 7. Except for the three solutions from Gayer and Leider (1955) (Nos. B2, B8, and A2 in Table H.3), saturation indices calculated for schoepite are in good agreement with the experimental studies that identify schoepite as a solubility control. The previous discussions of the modeling results for $\mathrm{UO}_{2}(\mathrm{OH})_{2}$ using the solubility data from Gayer and Leider (1955) will also pertain to the saturation indices calculated for schoepite using these same experimental data. Therefore, the indices (Table H.3) in Figure 4 for Gayer and Leider (1955) will receive no additional interpretation.

Robins (1966) identified schoepite as a precipitate in the solubility experiments completed at 25 and $50^{\circ} \mathrm{C}$. Similarly, the solution analyses (Table H.7) from the experiments at 25 and $50^{\circ} \mathrm{C}$ by Robins (1966) compute, respectively, to be at equilibrium and slightly oversaturated with respect to schoepite. The oversaturation calculated with respect to schoepite for the $50^{\circ} \mathrm{C}$ solution is in accord with the experimental data of Robins, because these solutions were modeled with the initial uranium concentration reported by Robins (1966).

The schoepite saturation indices (Table H.4) were also determined for solubility data selected from Miller (1958). In an electrometric titration experiment at $25^{\circ} \mathrm{C}$, Miller (1958) observed the precipitation of an urany? hydroxide solid starting at $\mathrm{pH}=4.5$ in a uranyl sulfate solution titrated with sodium hydroxide. These titration data are shown in Figure 5 of Miller (1958) and only include the initial culcentration of dissolved uranium. Based on the phase-stability data for U(VI) hydroxides by Robins (1966), we assumed that the hydroxide precipitate formed in this titration experiment was schoepite $\left[\mathrm{UO}_{2}(\mathrm{OH})_{2} \cdot \mathrm{H}_{2} \mathrm{O}\right]$. Saturation indices (filled circles in Figure 4 ) were calculated for schoepite using the initial uranium concentration listed by Miller (1958, Figure 5) for this titration experiment and $\mathrm{pH}$ values of 4.5 , 5.0, and 6.0. The saturation index for schoepite at $\mathrm{pH}=4.5(\log \mathrm{AP} / \mathrm{K}=$ -0.021) indicates that this solution is at equilibrium with respect to schoepite. This is in perfect agreement with the experimental observations made by Miller (1958). The initial uranium solution used for the titration 
experiment, however, computes to be increasingly oversaturated with respect to schoepite at $\mathrm{pH}$ values of 5.0 and 6.0 , which is consistent with his observed persistence of a uranyl hydroxide precipitate at these $\mathrm{pH}$ conditions.

Miller (1958, Figure 8) also described solubility data for uranyl hydroxide as a function of $\mathrm{pH}$ at $25^{\circ} \mathrm{C}$ in an aqueous solution free of any complexing ligands such as carbonate and phosphate. Saturations indices were determined for schoepite (half-filled circles in Figure 4) at final uranium concentrations reported at $\mathrm{pH}$ values of $4.7,5.8$, and 7.7 by Miller (1958, Figure 8). The schoepite index at $\mathrm{pH}=5.8$ is within the error band, and indicates that schoeptte is a permissible solubility control for uranium in this solution. The solutions at pH values of 4.7 and 7.7 calculate to be oversaturated with respect to schocpite. Although the saturation index for the solution at $\mathrm{pH}=4.7$ is close to the error band for a permissible solubility control, the calculated oversaturation may indicate that the reported urantum concentrations and/or $\mathrm{pH}$ values for these two solutions are inaccurate. Unfortunately, Miller (1958) does not describe how variable pH conditions were obtained in these solubility measurements involving uranyl hydroxide. If sodium hydroxide was used for the basic solutions, the solubility control in the solutions at $\mathrm{pH}=7.7$ might be a less soluble sodium uranate rather than schoepite.

EFFECTS OF HYDROXYL COMPLEXATION ON SOL.UBILITIES OF U(VI) SOLIDS

The saturation indices plotted in Figures 2,3 , and 4 for $\mathrm{UO}_{2}(\mathrm{OH})_{2}$ $\left[{ }^{\prime} \mathrm{B}-\mathrm{UO}_{2}(\mathrm{OH})_{2}\right.$ ' in Langmuir (1978)] and schoepite were calculated with the thermodynamic data in Langmuir (1978) for the aqueous complexes of uranium. As discussed in Appendix B, Langmuir (1978) does not include data for neutral and anionic hydroxyl complexes of U(VI). Including species in the thermodynamic data base will significantly affect the calculation of aqueous speciation and solubility controls for uranium in alkaline solutions. Sensitivity anaiyses were completed with WATEQ4 to demonstrate how the total concentration of dissolved uranium calculated for an aqueous solution in equilibrium with schoepite is affected by the addition of a neutral and anionic hydroxyl complex for U(VI). 
The results of these sensitivity analyses are shown in Figure 5 . The total concentration of dissolved uranium was calculated by assuming that the aqueous solution (or ground water) was in equilibrium with the mineral schoepite $\left[\mathrm{UO}_{2}(\mathrm{OH})_{2} \cdot \mathrm{H}_{2} \mathrm{O}\right]$ and contained no dissolved carbon dioxide. The activity of $U 0_{2}^{2+}$ [parent species used in WATEQ4 for the hydroxyl complex of $U(V I)]$ was computed as a function of $\mathrm{pH}$ at $25^{\circ} \mathrm{C}$ from $\log \mathrm{K}_{\mathrm{r}, \mathrm{T}}^{0}=5.404$ for the dissolution reaction:

$$
\mathrm{UO}_{2}(\mathrm{OH})_{2} \cdot \mathrm{H}_{2} \mathrm{O}+2 \mathrm{H}^{+}=\mathrm{UO}_{2}^{2+}+3 \mathrm{H}_{2} \mathrm{O}
$$

The above equilibrium is the same as that used in the thermodynamic data base in WATEQ4 to calculate the activity product (AP) and saturation index $(\log A P / K)$ for schoepite. Values of $E^{H}$ were calculated at the selected $\mathrm{pH}$ values from empirical relationship [Equation (7)],

$$
\mathrm{pE}+\mathrm{pH}=13.6 \text {. }
$$

The activities of $U 02^{+}$at the selected $\mathrm{pH}$ and $E^{H}$ values were then modeled with WATEQ4 to calculate the total concentration of dissolved uranium for a solution in equilibrium with schoepite.

These total concentrations are plotted as a function of $\mathrm{pH}$ in Figure 5. The dissolved uranium concentrations shown as line 1 in Figure 5 are those calculated using the thermodynamic data and uranium hydroxyl complexes in Langmuir (1978). At the alkaline $\mathrm{pH}$ conditions, $\left(\mathrm{UO}_{2}\right)_{3}(\mathrm{OH})_{5}^{+}$is the dominant uranium complex for solution compositions along line 1 . The complexes $\mathrm{UO}_{2}(\mathrm{OH}) 2$ and $\mathrm{UO}_{2}(\mathrm{OH})_{3}$ from Allard, Kipatsi, and Liljenzin (1980) were added to the thermodynamic data base of WATEQ4 to calculate the concentrations of dissolved uranium in equilihrium with schoepite along line 2 in Figure 5." By not replacing the thermodynamic data for all $U(V I)$ hydroxyl complexes in WATEQ4 with those values in Allard, Kipatsi, and Liljenzin (1980), the calculated uranium concentrations at acidic pH values in Figure 5 (line 2) may.be different than those concentrations determined solely from the thermodynamic data of the latter investigators. These inconsistencies should be minor at 


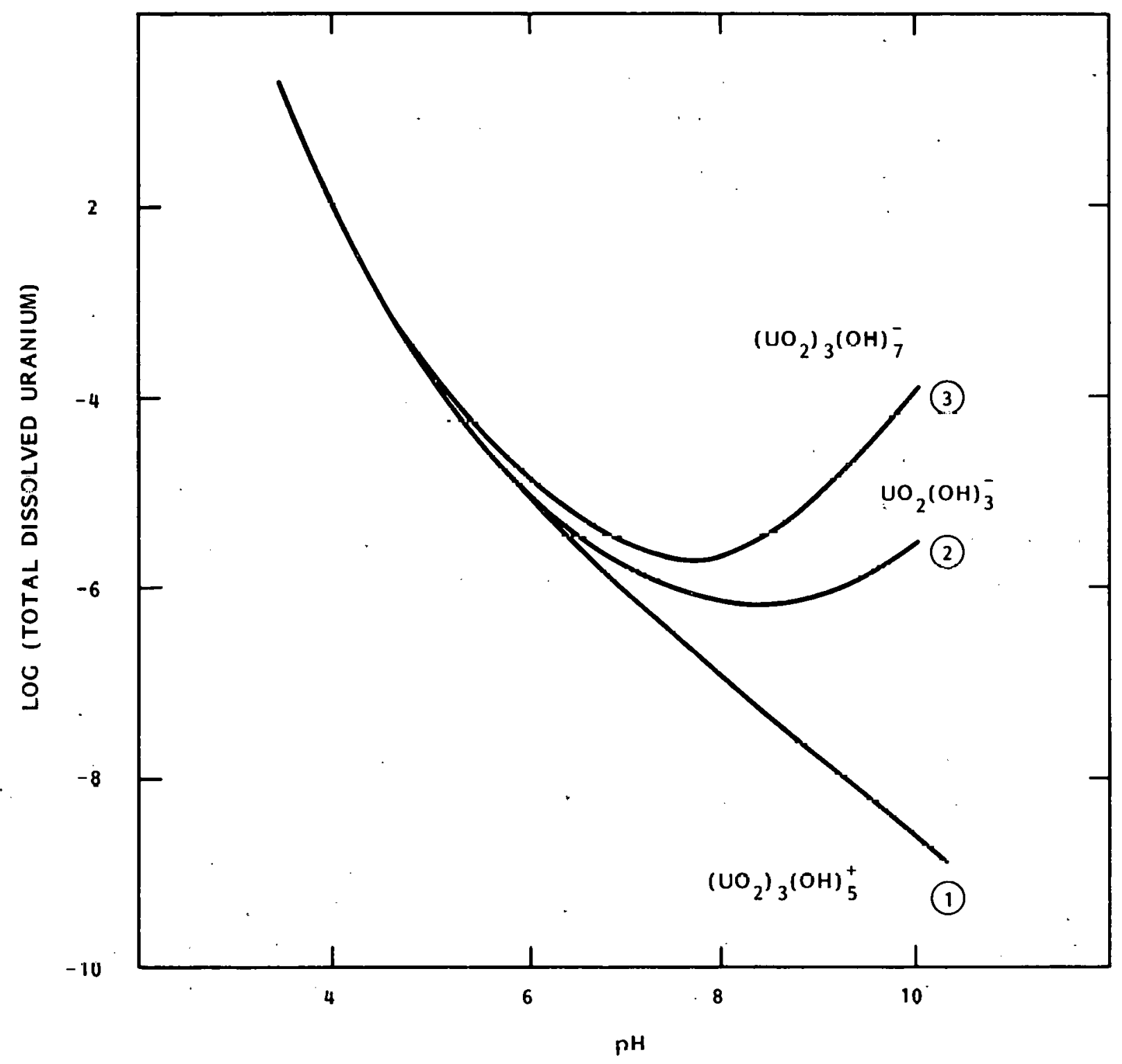

FIGURE 5. Total Concentration of Dissolved Uranium in Equilibrium at $25^{\circ} \mathrm{C}$ with Schoepite $\left[\mathrm{UO}_{2}(\mathrm{OH})_{2} \cdot \mathrm{H}_{2} \mathrm{O}\right]$ as a Function of $\mathrm{pH}$ 「Uranium concentrations àlong lines 1,2 , and 3 were computed, respectively, from thermodynamic data for U(VI) nydroxyl complexes from Langmuir (1978); Allard, Kipatsi, and Liljenzin (1980); and Lemire and Tremaine (1980.]

$\mathrm{pH}<6$ and will not affect our solub1lity calculations for the alkaline solutions. The concentrations of dissolved uranium in equilibrium witn schoepite were also calculated (Figure 5 , line 3) using tnermodynamic data for 
the aqueous complexes $\mathrm{UO}_{2}(\mathrm{OH}) 2$ and $\left(\mathrm{UO}_{2}\right)_{3}(\mathrm{OH})_{7}$ from Lemire and Tremaine (1980). Except for these neutral and anionic complexes, thermodynamic data in Lemire and Tremaine (1980) for the remaining U(VI) hydroxyl complexes were also the same as those in Langmuir (1978). At $\mathrm{pH}>8$, the complexes $\mathrm{UO}_{2}(\mathrm{OH}) \overline{3}$ and $\left(\mathrm{UO}_{2}\right)_{3}(\mathrm{OH}) \overline{7}$ dominate the speciation of $U(V I)$ in the calculated uranium solubilities along lines 2 and 3 , respectively, in Figure 5 .

At $\mathrm{pH}>7$, significant differences exist between the total uranium concentrations calculated from the thermodynamic data from Langmuir (1978) (Figure 5, line 1) and data sets that include neutral and anionic hydroxyl complexes of $U(V I)$ (Figure 5, lines 2 and 3 ). At a $\mathrm{pH}$ value of 9 and a corresponding $\mathrm{E}^{H}$ value of $0.271 \vee$ [from Equation (7)], the differences between the uranium concentrations calculated from the data of Langmuir (1978) and from those of Allard, Kipatsi, and Liljenzin (1980) and of Lemire and Tremaine (1980) are 1.8 and 2.9 orders of magnitude, respectively. Obviously, the results in Figure 5 demonstrate that solubility calculations for uranium in oxidizing, alkaline waters will be significantly different and possibly in gross error depending on whether or not the data base of a geochemical model includes an anionic hydroxyl complex for U(VI).

As discussed previously, solutions B2 and B8 (Table H.3.) from Gayer and Leider (1955) compute to be significiantly oversaturated with respect to the solids $\mathrm{UO}_{2}(\mathrm{OH})_{2}$ and schoepite. The saturation indices calculated with respect to $\mathrm{UO}_{2}(\mathrm{OH})_{2}$ for solutions $\mathrm{B} 2$ and $\mathrm{B} 8$ are, respectively, 1.9 and 2.3 (Figure 3 and Table H.3). The final $\mathrm{pH}$ value estimated from the starting concentration of sodium hydroxide is 11.6 for solutiun $B 2$ and 12.7 for solution $B 8$. If solutions $B 2$ and $B 8$ are remodeled with these $\mathrm{pH}$ values and by adding the thermodynamic data for the complexes $\mathrm{UO}_{2}(\mathrm{OH})_{2}^{0}$ and $\left(\mathrm{UO}_{2}\right)_{3}(\mathrm{OH})_{7}$ to WATEQ4, the saturation indices calculated for solutions $\mathrm{B} 2$ and $\mathrm{B} 8$ with respect to $\mathrm{UO}_{2}(\mathrm{OH})_{2}$ (and similarly schoepite) are -0.79 and -1.13 , respectively. These saturation indices fall outside of the error band for permissible solubility control with respect to $\mathrm{UO}_{2}(\mathrm{OH})_{2}$. Similar saturation indices for $\mathrm{UO}_{2}(\mathrm{OH})_{2}$ were calculated for these two solutions using thermodynamic data for the complexes $\mathrm{UO}_{2}(\mathrm{OH})_{2}^{0}$ and $\mathrm{UO}_{2}(\mathrm{OH})_{\overline{3}}$ from Allard, Kipatsi, and Liljenzin (1980). 
Based on the modeling results obtained by including the neutral and anionic $U(V I)$ hydroxyl complexes in. WATEQ4, solutions B2 and B8 are undersaturated with respect to uranyl hydroxide solids. The descriptions of laboratory studies reviewed in this validation study would indicate that uranyl hydroxides precipitate readily in solutions studied under laboratory conditions. This observation would therefore suggest that the initial calculation of oversaturation of solutions $B 2$ and $B 8$ with respect to uranyl hydroxide solids (Figure 2 and 4) was based on incorrect thermodynamic data and/or estimated $\mathrm{pH}$ values. If one assumes that the estimated final $\mathrm{pH}$ values for solutions B2 and B8 are approximately correct, the undersaturation of solutions $B 2$ and $B 8$ with respect to $\mathrm{UO}_{2}(\mathrm{OH})_{2}$ and schoepite is consistent with the possibility that another solid (e.y.. d sodfum uranate) is controlling the concentrations of uranium in solutions $B 2$ and $B 8$. Alternatively, one may assume that $\mathrm{UO}_{2}(\mathrm{OH})_{2}$ or schoepite was a solubility control for uranium in solutions $B 2$ and $B 8$ and that the estimated $\mathrm{pH}$ values for these two solutions are grossly in error. The results of modeling solution $B 2$ at a series of $\mathrm{pH}$ values between 7 and 11.6 with the complexes $\mathrm{UO}_{2}(\mathrm{OH})_{2}^{0}$ and $\left(\mathrm{UO}_{2}\right)_{3}(\mathrm{OH})_{7}^{-}$in the WATEQ4 data base indicate that solution $B 2$ is at equilibrium (log $A P / K=0$ ) with $\mathrm{UO}_{2}(\mathrm{OH})_{2}$ at $\mathrm{pH}=9.2$. This equilibrium $\mathrm{pH}$ value is more reasonable for these sodium hydroxide solutions than the $\mathrm{pH}$ value of 6.1 (discussed previously) similarly estimated for solution B2 using the thermodynamic data from Langmuir (1978).

Unfortunately, the available solution analyses selected from laboratory studies of uranyl hydroxide solids cannot be used to confirm or dismiss the existence of a neutral and anionic hydroxyl complex for U(VI). Our estimated $\mathrm{pH}$ values for solutions B2 and B8 from Gayer and Leider (1955) can be in considerable error. The remaining solubility data for uranyl hydroxide solids from Brusin (1y8u), Gayer and Leider (1955), Miller (1958), and Robins (1966) are for aqueous solutions with $\mathrm{pH}$ values $<7$ (Figures 3 and 4 ). Therefore, the saturation indices with respect. to $\mathrm{UO}_{2}(\mathrm{OH})_{2}$ and schoepite for the solutions selected from these four studies [except solutions B2 and B8 from Gayer and Leider (1955)] did not change when these solutions were remodeled with the complexes $\mathrm{UO}_{2}(\mathrm{OH})_{2}$ and $\left(\mathrm{UO}_{2}\right)_{3}(\mathrm{OH})_{7}$ in the WATEQ4 data base. Therefore, solubility data for uranium hydroxides and other U(VI) solids (to be discussed 
in subsequent sections) in alkaline solutions are not sufficient to validate the existence of neutral and anionic hydroxyl complexes for $U(V I)$.

Although the mineral schoepite was selected for sensitivity analyses discussed in this section, the results in Figure 5 will be similarly important for all solubility calculations involving uranium in oxidizing, alkaline aqueous solutions and ground waters. However, in alkaline waters containing dissolved carbon dioxide, the importance of the neutral and anionic U(VI) hydroxyl complexes will be diminished because of the domination of uranyl carbonate complexation (Langmuir 1978).

RUTHERFORDINE $\left(\mathrm{UO}_{2} \mathrm{CO}_{3}\right)$

Sergeyeva et al. (1972) investigated the solubility of the mineral rutherfordine $\left(\mathrm{UO}_{2} \mathrm{CO}_{3}\right)$ in sodium bicarbonate and perchloric acid solutions. Solution analyses at 25 and $50^{\circ} \mathrm{C}$ (Table H.8) were selected from Sergeyeva et al. (1972) for modeling purposes. The saturation indices determined for these solutions with respect to rutherfordine are listed in Table H.9 and shown in Figure 6 as a function of $\mathrm{pH}$. The error band $\left( \pm 1 / 20 \times \log \mathrm{K}_{\mathrm{r}, \mathrm{T}}^{0}\right)$ for a permissible solubility control was calculated from the $\log K_{r}^{0}, T$ for the dissolution of rutherfordine at $25^{\circ} \mathrm{C}$. All of the selected solutions from Sergeyeva et al. (1972) compute to be at equilibrium with rutherfordine.

The exceptional agreement between the modeling results and the published solubility experiments of Sergeyeva et al. (1972) do not, however, provide a complete validation test of the WATEQ4 model and its data base. Because the thermodynamic data for rutherfordine and the complexes $\mathrm{UO}_{2} \mathrm{CO}_{3}^{0}$ and $\mathrm{UO}_{2}\left(\mathrm{CO}_{3}\right)_{3}^{4-}$ are themselves derived from the thermodynamic data from Sergeyeva et al. (1972), (a) the agreement between the modeling results and these solubility experiments demonstrates the internal consistency between the thermodynamic data base of WATEQ4 and the results of Sergeyeva et al. (1972). At pH> 5, the uranyl carbonate complexes $\mathrm{UO}_{2} \mathrm{CO}_{3}, \mathrm{UO}_{2}\left(\mathrm{CO}_{3}\right)_{2}^{2-}$, and $\mathrm{UO}_{2}\left(\mathrm{CO}_{3}\right)_{2}^{4-}$ dominate the mass distribution of uranium dissolved in oxidizing, uranium-carbonate waters. The

(a) The derivation of these thermodynamic data are described in Langmuir (1978, p. 551). 


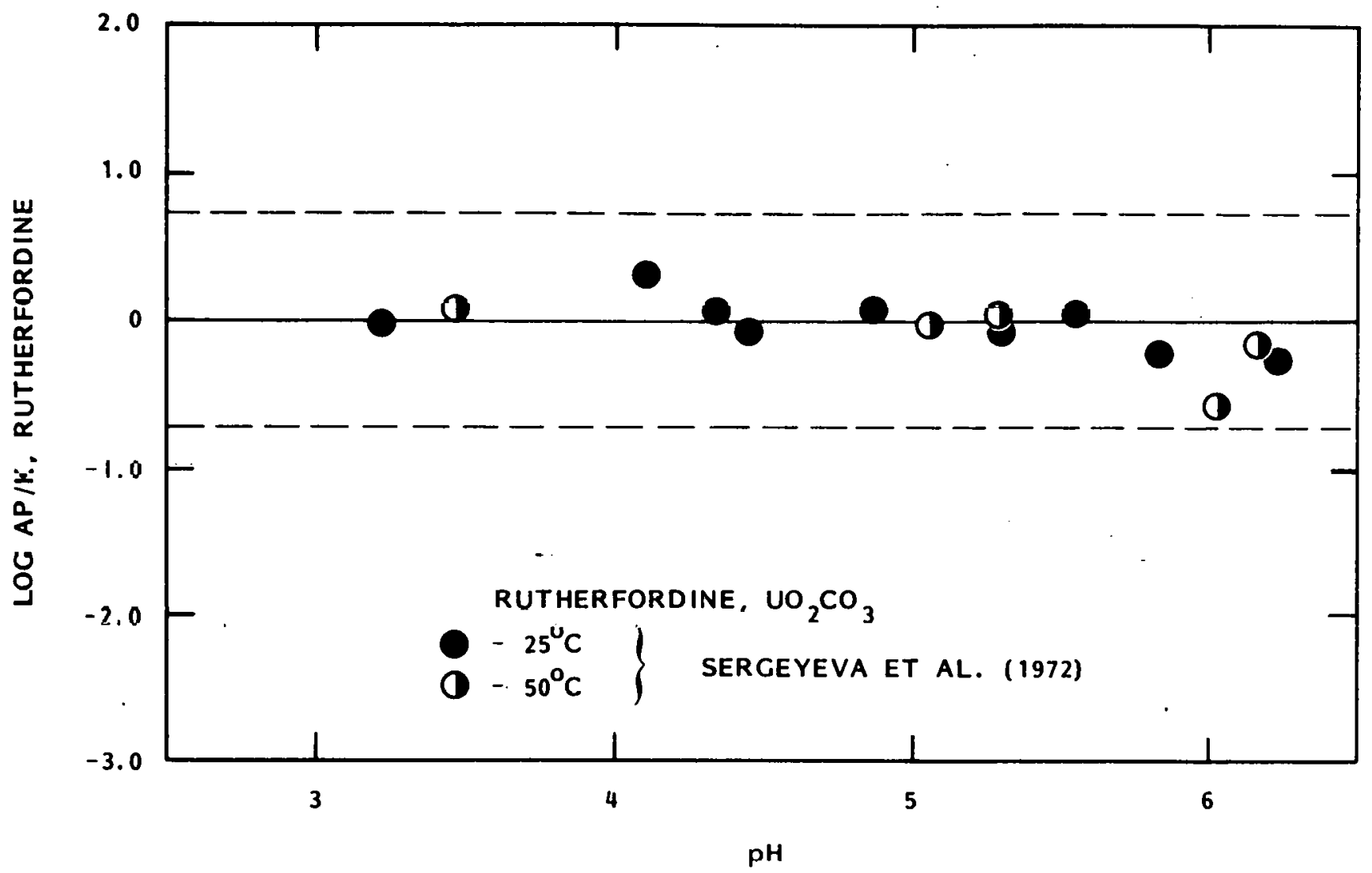

FIGURE 6. Rutherfordine $\left(\mathrm{UO}_{2} \mathrm{CO}_{3}\right)$ Saturation Indices Plotted Versus $\mathrm{pH}$

complex $\mathrm{U}_{2}^{2+}$, on the other hand, is the dominant species in uranium-carbonate waters with $\mathrm{pH}$ values of $\langle 5$. Therefore, the rutherfordine saturation indices (Figure 6) for the six solutions selected from Sergeyeva et al. (1972), that have $\mathrm{pH}$ values $<6$, provide a better validation test of the speciation submodel of WATEQ4 because the thermodynamic data for the complex $\mathrm{U}_{2} 2_{2}^{+}$are independent of the solubility experiments by Sergeyeva et al. (1972).

The results of modeling the aqueous solutions from Sergeyeva et al. (19\%2) also provide a validation of the corrections calculated in WATEQ4 for the ionic strengths and temperatures of these solutions. The ionic strengt.ns of the solutions selected from Sergeyeva et al. (1972) varied between 0.0002 and 0.027 , and some of these solubility experiments were completed at $50^{\circ} \mathrm{C}$.

Unfortunately, the Investigation by Sergeyeva et al. (1972) was the only study that met the acceptance criteria for rutherfordine. These data, 
moreover, are restricted to a narrow $\mathrm{pH}$ range between 3 and 6.5 (Figure 6). No published laboratory or field studies were found that would permit a validation of WATEQ4 for rutherfordine and the uranyl carbonate complexes in alkaline waters. In laboratory studies of uranyl carbonate speciation, Ciavatta et al. (1981) and Ferri, Grenthe, and Salvatore (1981) observed the precipitation of $\mathrm{UO}_{2} \mathrm{CO}_{3}$ during potentiometric measurements in $3 \mathrm{M}$ sodium perchlorate medium. Because the ionic strengths of these solutions exceeded the capabilities for ionic strength corrections in WATEQ4, solution analyses from Ciavatta et al. (1981) and Ferri, Grenthe, and Salvatore (1981) were not be used.

URANYL PHOSPHATES

Solution analyses from laboratory solubility studies of uramphite $\left[\left(\mathrm{NH}_{4}\right)_{2}\left(\mathrm{UO}_{2}\right)_{2}\left(\mathrm{PO}_{4}\right)_{2}\right],(\mathrm{a})$ K-autunite $\left[\mathrm{K}_{2}\left(\mathrm{UO}_{2}\right)_{2}\left(\mathrm{PO}_{4}\right)_{2}\right]$, and $\mathrm{H}$-autunite $\left[\mathrm{H}_{2}\left(\mathrm{UO}_{2}\right)_{2}\left(\mathrm{PO}_{4}\right)_{2}\right]$ by Chukhlantsev and Stepanov (1956), of H-autunite by Moskvin, Shelyakina, and Perminov (1967), and of H-autunite and autunite $\left[\mathrm{Ca}\left(\mathrm{UO}_{2}\right)_{2}\left(\mathrm{PO}_{4}\right)_{2}\right]$ by Muto (1965) were used in the uranium validation study. The solution analyses selected from these three studies are listed in Tables H.2a, H.5a, and H.6a, respectively. The saturation indices calculated for these aqueous solutions with respect to uramphite, K-autunite, H-autunite, autunite, $\left(\mathrm{UO}_{2}\right)_{3}\left(\mathrm{PO}_{4}\right)_{2}$, and schoepite are summarized in Table 2. The saturation indices for the uranyl. phosphate solids were calculated with the assumption that the thermodynamic data for the uranyl phosphate complexes in Langmuir (1978) and Dongarra and Langmuir (1980) are accurate and complete. (b)

In general, the calculated solubility controls for the solution analyses from Cnukhlantsev and Stepanov (1956), Moskvin, Shelyakina, and Perminov (1967), and Muto (1965) are in poor agreement with the solubility controls indicated by the authors of those laboratory studies. Solution analyses from solubility studies of uramphite (Table 2, sample numbers $A 1$ to $A 6$ ) and K-autunite (Table 2, sample numbers $K 1$ to $K 6$ ) calculate to be undersaturated

(a) The formulas accepted in the WATEQ4 data base for these uranyl phosphate minerals are the same as those given in Langmuir (1978). The $\mathrm{H}_{2} \mathrm{O}$-units have been deleted from these formulas because tney are poorly known.

(b) Indications of possible problems with the thermodynamic data for the uranyl phosphate complexes are briefly described in Appendix D. 
TABLE 2. Saturation Indices for Selected Uranium Solids Calculated for Solution Analyses from Published Laboratory Studies of Uranyl Phosphates [Saturation indicates that fall witnin the equilibrium error bands have been noted with asterisks.]

Saturation Indices

\begin{tabular}{|c|c|c|c|c|c|c|c|c|c|}
\hline \multirow{2}{*}{$\begin{array}{l}\text { Sample } \\
\text { Number (a) }\end{array}$} & \multirow[b]{2}{*}{$T$} & \multirow[b]{2}{*}{$\mathrm{pH}$} & \multicolumn{7}{|c|}{ saturation indices } \\
\hline & & & $\left(\mathrm{UO}_{2}\right)_{3}\left(\mathrm{PO}_{4}\right)_{2}$ & H-Autunite & Urampnite & K-Autunite & Autunite & Na-Autunite & Scnoepite \\
\hline & $\left({ }^{\circ} \mathrm{C}\right)$ & & $( \pm 2.45)^{(b)}$ & $( \pm 2.40)$ & $( \pm 2.59)$ & $( \pm 2.41)$ & $( \pm 2.20)$ & $( \pm 2.37)$ & $( \pm 0.27)$ \\
\hline & & & \multicolumn{7}{|c|}{ Chuknlantsev and Stepanov $(1956)(\mathrm{c})$} \\
\hline Al & 19.5 & 1.85 & $-1.11^{\star}$ & -3.38 & -2.71 & -- & $\therefore$ & -- & -6.76 \\
\hline A3 & 19.5 & 2.35 & $-1.26^{\star}$ & -4.14 & -3.39 & -- & -- & -- & -5.15 \\
\hline A4 & 19.5 & 1.90 & $-1.81 *$ & -3.81 & -3.07 & -- & -- & -- & -6.03 \\
\hline A6 & 19.5 & 2.35 & $-1.77^{\star}$ & -4.42 & -3.64 & -- & -- & -- & -5.39 \\
\hline k1 & 19.5. & 2.05 & $1.77^{\star}$ & $-1.63 *$ & $=-$ & -2.43 & -- & -- & -4.63 \\
\hline K3 & 19.5 & 2.85 & $1.81^{\star}$ & -2.66 & -- & -3.07 & -- & -- & -3.56 \\
\hline$K 4$ & 19.5 & 2.00 & $0.80 *$ & $-2.09 *$ & -- & -3.05 & -- & .. & -5.14 \\
\hline K6 & 19.5 & 2.80 & $1.51^{\star}$ & -2.70 & -- & -2.92 & -. & -- & -3.82 \\
\hline $\mathrm{H} 2$ & 19.5 & 2.10 & $0.92^{\star}$ & $-2.28 *$ & -- & -- & -- & -- & -4.84 \\
\hline H4 & 19.5 & 2.05 & $0.94 *$ & $-2.20^{\star}$ & -- & -. & -- & -- & -4.90 \\
\hline
\end{tabular}
Moskvin, Snelyakina, and Perminov $(1967)^{(c)}$

$\begin{array}{lllllllllr}\text { A1 } & 25 & 4.00 & 0.20^{\star} & -4.28 & -- & -- & -- & -- & -2.03 \\ \text { A2 } & 25 & 0.70 & -2.10^{\star} & -10.15 & -- & -- & -- & 5.85 & 1.22 \\ \text { A3 } & 25 & 4.20 & 1.39^{\star} & -3.75 & -- & -- & -- & 3.26 & -1.39 \\ \text { A4 } & 25 & 2.00 & -2.88 & -3.78 & & -- & -- & -1.18^{*} & -5.63 \\ \text { A5 } & 25 & 1.80 & -0.84^{\star} & -2.08^{\star} & -- & -- & -- & 0.13^{\star} & -5.29 \\ \text { A10 } & 25 & 1.10 & -0.65^{\star} & -1.04^{\star} & -- & -- & -- & -0.23^{\star} & -6.14 \\ \text { A11 } & 25 & 1.08 & -0.58^{\star} & -0.98^{\star} & -- & -- & -- & -- & -6.11 \\ \text { A18 } & 50 & 1.13 & -4.76 & 0.20^{\star} & -- & -- & -- & -- & -5.20 \\ \text { A25 } & 70 & 1.13 & -8.16 & 0.71^{\star} & -- & -- & -- & -- & -4.76\end{array}$

Muto $(1965)^{(c)}$

$\begin{array}{llllllllll}7 & 25 & 3.02 & -1.51^{*} & -4.17 & -- & -- & -6.64 & -- & -3.86 \\ 8 & 2 . . & 3.79 & -2.28^{*} & -5.71 & -- & -- & -7.40 & -- & -3.09 \\ 9 & 25 & 4.78 & -1.32^{\star} & -6.29 & -- & -- & -6.23 & -- & -1.54 \\ 10 & 25 & 1.80 & -2.61 & -3.37 & -- & -- & -- & -- & -5.75 \\ 11 & 25 & 2.34 & -2.21^{*} & -3.78 & -- & -- & -- & -- & -4.94 \\ 12 & 25 & 3.23 & -1.93^{\star} & -4.73 & -- & -- & -- & -- & -3.71\end{array}$

(a) Sample numbers are identical to those used in tables for these same references in Appendix $H$.

(b) Numbers listed in this row are the error bands $\left( \pm 1 / 20 \times 10 g, k_{r, T}^{\delta}\right)$ at $25^{\circ} \mathrm{C}$ for permissive equilibrium with each tabulated solid.

(c) Investigators calculated concentrations of dissolved phosphate from uranium concentrations, assuming congruent dissolution of the phosphate solids. 
with respect to these two uranyl phosphate solids. The saturation indices determined for these eight solutions with respect to uramphite and $K$-autunite are below the error band for a permissive solubility control. The undersaturation of solutions $A 1$ to $A 6$ with respect to uramphite is difficult to explain because the thermodynamic data for uramphite $\left[\left(\mathrm{NH}_{4}\right)_{2}\left(\mathrm{UO}_{2}\right)_{2}\left(\mathrm{PO}_{4}\right)_{2}\right]$ in Langmuir (1978) were taken from the same solubility data in Chukhlantsev and Stepanov (1956). Solution analyses $\mathrm{H} 2$ and $\mathrm{H} 4$ were taken from solubility studies of $\mathrm{H}$-autunite. Although solutions $\mathrm{H} 2$ and $\mathrm{H} 4$ from Chukhlantsev and Stepanov (1956) compute to be undersaturated with respect to $\mathrm{H}$-autunite, the saturation indices for $\mathrm{H}$-autunite (Table 2) lie within the error band $( \pm 2.40)$ for this solid to be a permissive solubility control for these two solutions.

All of the aqueous solutions selected from Chukhlantsev and Stepanov (1956), however, calculate to be in equilibrium with the solid $\left(\mathrm{UO}_{2}\right)_{3}\left(\mathrm{PO}_{4}\right)_{2}$. The saturation indices computed for solutions $\mathrm{Al}$ to $\mathrm{H} 4$ with respect to $\left(\mathrm{UO}_{2}\right)_{3}\left(\mathrm{PO}_{4}\right)_{2}$ are all well within the error band $( \pm 2.45)$ for a permissive solubility control. Chukhlantsev and Stepanov (1956), unfortunately, never discuss the possibility that $\left(\mathrm{UO}_{2}\right)_{3}\left(\mathrm{PO}_{4}\right)_{2}$ might be a reaction product in their solubility experiments. Moreover, based on their experimental procedures, Chukhlantsev and Stepanov (1956) would not have identified the precipitation of additional solids in their "dissolution" experiments. Although they identified the synthetic solids added to their leachate solutions, the solids in equilibrium with the final solutions were never characterized. Secondly, because the uranyl phosphate solids were assumed to dissolve congruently, Chukhlantsev and Stepanov. (1956) analytically determined only the $\mathrm{pH}$ values and total concentrations of dissolved uranium in the final aqueous solutions. The equilibrium concentrations of dissolved ammonia, potassium, and phosphate were calculated by Chukhlantsev and Stepanov (1956) from the ratios of those constituents (e.g., $\mathrm{NH}_{4}, \mathrm{~K}$, and $\mathrm{PO}_{4}$ ) to uranium in the formula unit and the analytically determined concentrations of dissolved uranium (see Appendix $H$ ). The reader should also note that the final $\mathrm{pH}$ values (Table 2 ) for the solubility experiments of Chukhlantsev and Stepanov (1956) cover the narrow range between 1.85 and 2.85 . 
Moskvin, Shelyakina, and Perminov (1967) investigated the solubility of $\mathrm{UO}_{2} \mathrm{HPO}_{4} \cdot 4 \mathrm{H}_{2} \mathrm{O}$, which was assumed to be equivalent to the mineral $\mathrm{H}$-autunite $\left[\mathrm{H}_{2}\left(\mathrm{UO}_{2}\right)_{2}\left(\mathrm{PO}_{4}\right)_{2}\right]$. Solutions $\mathrm{A} 5$ to $\mathrm{A} 25$ (Table 2 ) with $\mathrm{pH}$ values between 1.08 and 1.80 from Moskvin, Shelyakina, and Perminov (1967) calculate to be in equilibrium with $\mathrm{H}$-autunite, which is agreement with their laboratory experiments. The H-autunite saturation indices for solutions with higher $\mathrm{pH}$ values (Table 2, sample numbers A1 to A4), however, fall below the equilibrium error band and indicate that these four aqueous solutions are undersaturated with respect to $\mathrm{H}$-autunite. This disagreement between the modeling and experimental results is surprising, because the thermodynamic data for $\mathrm{H}$-autunite in Langmuir (1978) and, thus, the. WATEQ4 data base, were derived from the same solubility data in Moskvin, Shelyakina, and Perminov (1967).

Except for solution A4, all of the solution analyses at $25^{\circ} \mathrm{C}$ from Moskvin, Shelyakina, and Perminov (1967) calculate to be in equilibrium with the solid $\left(\mathrm{UO}_{2}\right)_{3}\left(\mathrm{PO}_{4}\right)_{2}$. The saturation index $(-2.88)$ for solution $A 4$ with respect to $\left(\mathrm{UO}_{2}\right)_{3}\left(\mathrm{PO}_{4}\right)_{2}$ is just below the error band $( \pm 2.45)$ for a permissive solubility control. As in Chukhlantsev and Stepanov (1956), $\left(\mathrm{UO}_{2}\right)_{3}\left(\mathrm{PO}_{4}\right)_{2}$ was not considered by Moskvin, Shelyakina, and Perminov (1967) as a possible reaction product in their dissolution experiments. Moskvin, Shelyakina, and Perminov (1967) did not characterize the solids in equilibrium with the final leachate solutions. Moreover, the equilibrium concentration of dissolved phosphate was calculated from the analytically determined concentration of dissolved uranium and the assumption of congruent dissolution of H-autunite.

Two other aspects should be noted with respect to the saturation indices calculated for the solution analyses from Moskvin, Shelyakina, and Perminov (1967). For the solubility experiments completed in $0.5 \mathrm{M}$ sodium perchlorate solutions, solution analyses $A 2$ to $A 10$ in Table 2 calculate to be in equilibrium or oversaturated with respect to Na-autunite. As described in Appendix $H$, the concentration of dissolved sodium was estimated from the initial concentration of sodium perchlorate solution. Therefore, the saturation indices indicating oversaturation of solutions $A 2$ and A3 from Moskvin, 
Shelyakina, and Perminov (1967) with respect to Na-autunite are still consistent with this solid being a permissive solubility control for these solutions.

Secondly, solutions A11, A18, and A25 from Moskvin, Shelyakina, and Perminov (1967) exhibit an extraordinary decrease in the saturation indices of $\left(\mathrm{UO}_{2}\right)_{3}\left(\mathrm{PO}_{4}\right)_{2}$ with increasing temperature. Solutions $\mathrm{A} 11$, $\mathrm{A} 18$, and $\mathrm{A} 25$ (Table 2) were from solubility measurements completed in the same initial concentration of nitric acid, but at temperatures of 25,50 , and $70^{\circ} \mathrm{C}$, respectively. The $H$-autunite saturation indices $(\log A P / K)$ for solutions $A 11, A 18$, and $A 25$ exhibit a less dramatic change ( 1.7 units) between 25 and $70^{\circ} \mathrm{C}$, than the change of saturation indices for $\left(\mathrm{UO}_{2}\right)_{3}\left(\mathrm{PO}_{4}\right)_{2}$ (8.9 units). As previously described, the equilibrium constants in the WATEQ4 data base are corrected for temperature using the van't Hoff relation [Equation (4)]. Therefore, the different temperature-dependencies of the solubilities of $\mathrm{H}$-autunite and $\left(\mathrm{UO}_{2}\right)_{3}\left(\mathrm{PO}_{4}\right)_{2}$ may be correct, or they may indicate that our derived $\Delta H_{f, 298}^{0}$ for $\left(\mathrm{UO}_{2}\right)_{3}\left(\mathrm{PO}_{4}\right)_{2}$ (Appendix E), although internally consistent with the available $\Delta G_{f, 298}^{0}$ and $S_{298}^{0}$ values in Langmuir (1978), is still in error.

Solution analyses 7 to 9 and 10 to 12 (Table H.6a) were selected, respectively, from solubility studies of autunite $\left[\mathrm{Ca}\left(\mathrm{UO}_{2}\right)_{2}\left(\mathrm{PO}_{4}\right)_{2}\right]$ and $\mathrm{H}$-autunite by Muto (1965). Based on the calculated saturation indices (Table 2), these solutions are significantly undersaturated with respect to autunite and H-autunite. However, all solution analyses, except sample number 10, from Muto (1965) calculate to be in equilibrium with the solid $\left(\mathrm{UO}_{2}\right)_{3}\left(\mathrm{PO}_{4}\right)_{2}$. The $\left(\mathrm{UO}_{2}\right)_{3}\left(\mathrm{PO}_{4}\right)_{2}$ saturation index for solution analysis 10 is -2.61 , which is just outside the error band $( \pm 2.45)$ for equilibrium solubility with respect to this solid. As with the other solubility studies of uranyl phosphate solids, the solids in equilibrium with the final aqueous solutions were not characterized and the equilibrium concentrations of dissolved calcium and phosphate were calculated from the concentrations of dissolved uranium.

The validation study of WATEQ4 with respect to the uranyl phosphate solids may have also exposed a new potential source of error in the solubility measurements by Chukhlantsev and Stepanov (1956), Moskvin, Shelyakina, and Perminov (1967) and Muto (1965) and, subsequently, in thermodynamic data 
derived from those investigations. Except for two solutions, all of the solution analyses calculate to be in equilibrium with the solid $\left(\mathrm{UO}_{2}\right)_{3}\left(\mathrm{PO}_{4}\right)_{2} \cdot$. This solid, however, was not used or looked for in those laboratory solubility studies. If the thermodynamic data for the uranyl phosphate complexes and $\left(\mathrm{UO}_{2}\right)_{3}\left(\mathrm{PO}_{4}\right)_{2}$ are correct, the solid $\left(\mathrm{UO}_{2}\right)_{3}\left(\mathrm{PO}_{4}\right)_{2}$ may have been a solubility control for uranium for the aqueous solutions listed in Table 2. Unfortunately, this possibility cannot be verified from the avallable experimental data. The solids in equilibrium with the final leachate solutions were never characterized, and the equilibrium concentration of dissolved uranium was the only constituent (besides $\mathrm{pH}$ ) analytically determined. Because the atomic ratio of uranium and phosphorous differ hetween the autunite minerals and $\left(\mathrm{UO}_{2}\right)_{3}\left(\mathrm{PO}_{4}\right)_{2}$, analyses of dissolved phosphate concentrations may have provided sufficient evidence for additional precipitates in these experiments. For the autunite series of minerals (including uramphite), the atumlc raliu ur urdilium to phosphorous in their ideal formula units is $1: 1$. However, the atomic ratio of uranium to phosphorous in $\left(\mathrm{UO}_{2}\right)_{3}\left(\mathrm{PO}_{4}\right)_{2}$ is $3: 2$.

Solubility relations between $\left(\mathrm{UO}_{2}\right)_{3}\left(\mathrm{PO}_{4}\right)_{2}$ and $\mathrm{H}$-autunite (and the other autunite minerals), nevertheless, can be used to construct a consistent interpretation of the modeling results in Table 2. The saturation indices for $\mathrm{H}$-autunite and $\left(\mathrm{UO}_{2}\right)_{3}\left(\mathrm{PO}_{4}\right)_{2}$ that were calculated for solutions $\mathrm{H} 2$ and $\mathrm{H} 4$ from Chukhlantsev and Stepanov (1956), Al to All from Moskvin, Shelyakina, and Permiriov (1967), and 10 to 12 from Muto (1965) are shown in two plots as a function of $\mathrm{pH}$ in Figure 7. These twelve solution analyses were from solubility studies in which $\mathrm{H}$-autunite was the starting solid in the dissolution experiments. Except for one solution analysis [sample number A2 from Moskvin, Shelyakina, and Perminov (1967)], these solubility data are restricted to the $\mathrm{pH}$ range between 1 and 4 . Figure 7 shows that these solutions become increasingly undersaturated with respect to $\mathrm{H}$-autunite $\left[\mathrm{H}_{2}\left(\mathrm{UO}_{2}\right)_{3}\left(\mathrm{PO}_{4}\right)_{2}\right]$ with an increase in their $\mathrm{pH}$ values.

The pH-dependency exhibited in the saturation indices in Figure 7 can be explained by the solubilities of these uranyl phosphate solids relative to each other. The equilibrium solubilities of $\mathrm{H}$-autunite, $\left(\mathrm{UO}_{2}\right)_{3}\left(\mathrm{PO}_{4}\right)_{2}$, and schoepite at $25^{\circ} \mathrm{C}$ are depicted as a function of $\mathrm{pH}$ in Figure 8 . The solubility 

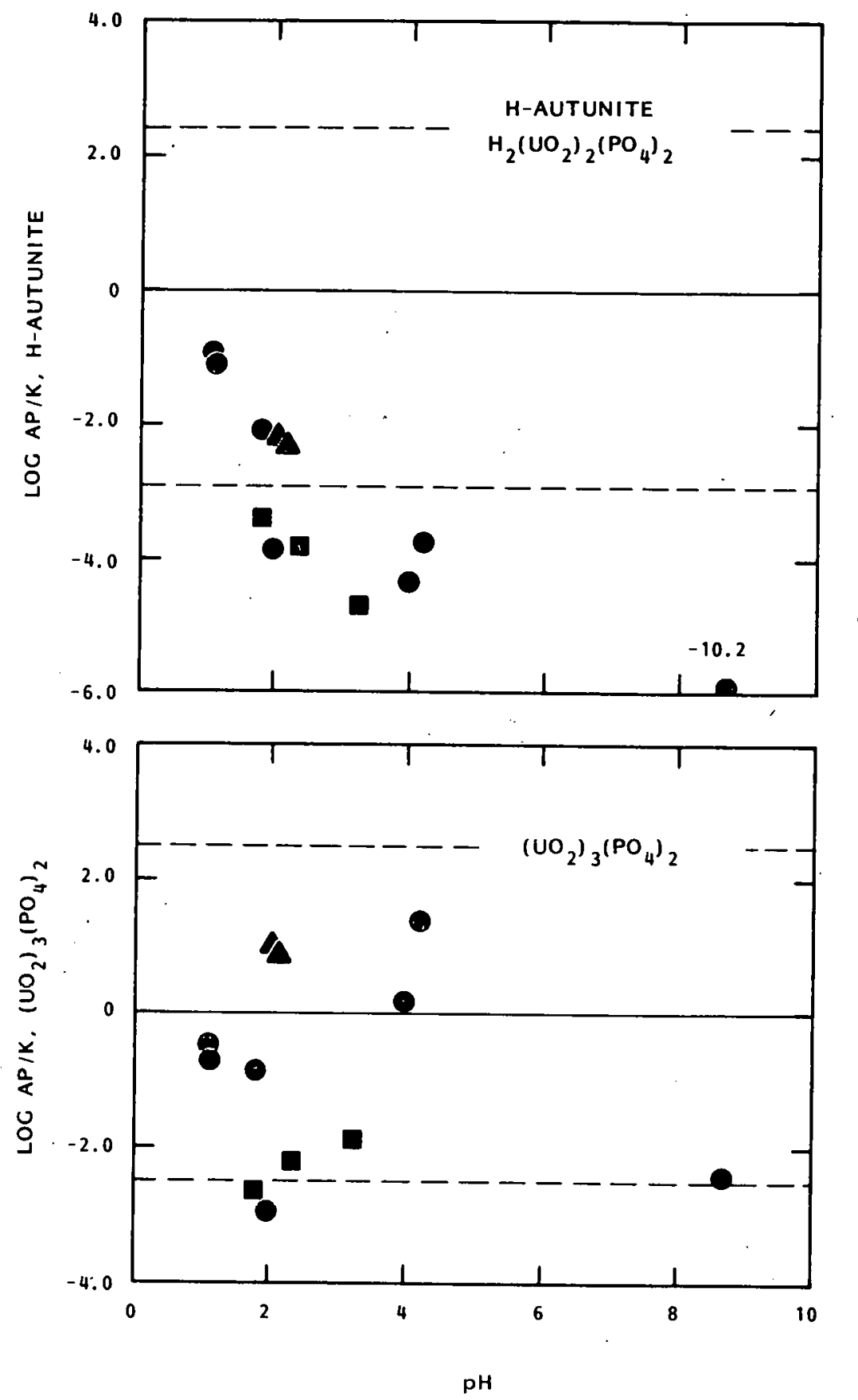

FIGURE 7. Saturation Indices for H-Autunite and $\left(\mathrm{UO}_{2}\right)_{3}\left(\mathrm{PO}_{4}\right)_{2}$ Plotted as a Function of $\mathrm{pH}$ [Saturation indices calculated for solution analyses selected from solubility studies of $\mathrm{H}$-autunite. The filled triangles, circles, and squares represent solutions selected, respectively, from Cnuknlantsev and. Stepanov (1956), Moskvin, Shelyakina, and Perminov (1967), and Muto (1965).] 


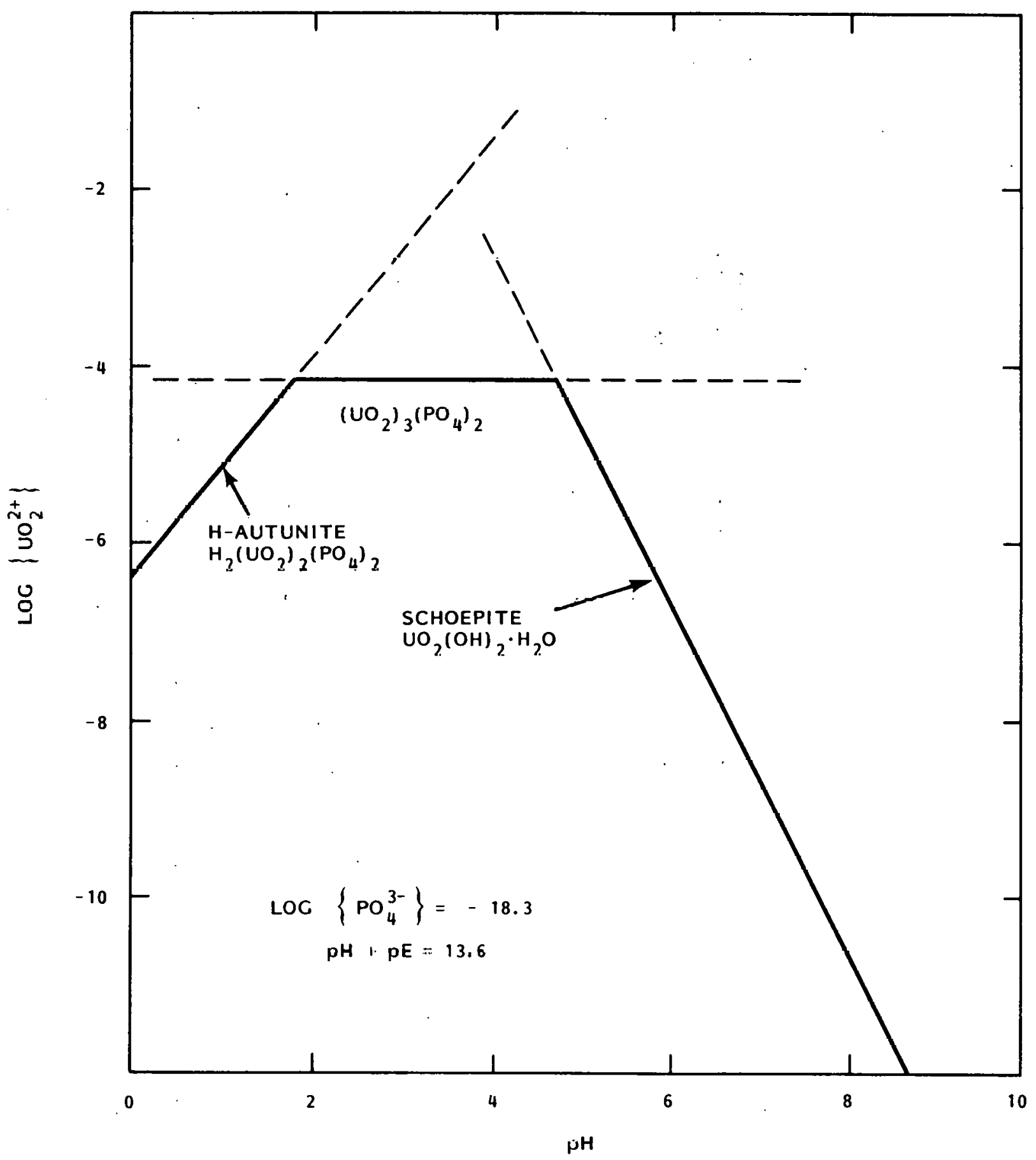

FIGURE 8. Activity of the Aqueous Species $U 0_{2}^{2+}$ in Equilibrium at $25^{\circ} \mathrm{C}$ with $\mathrm{H}$-Autunite, $\left(\mathrm{UO}_{2}\right)_{3}\left(\mathrm{PO}_{4}\right)_{2}$, and Schoepite as a Function of $\mathrm{pH}$ at the Indicated Activity of $\mathrm{PO}_{4}^{-}$. [Because no mineral with the composition $\left(\mathrm{UO}_{2}\right)_{3}\left(\mathrm{PO}_{4}\right)_{2}$ has been identified in a geologic environment, $\left(\mathrm{UO}_{2}\right)_{3}\left(\mathrm{PO}_{4}\right)_{2}$ will probably not be a solubility control for uranium in natural waters.] 
calculations in figure 8 were simplified by fixing the log of the activity of the aqueous species $\mathrm{PO}_{4}^{3-}$ at -18.3 . The $\mathrm{PO}_{4}^{3-}$ activity was taken for this example from the aqueous speciation calculated for solution 12 from Muto (1965) and, at $\mathrm{pH}=3.23$, corresponds to a total concentration of dissolved phosphate of $3.715 \times 10^{-5} \mathrm{~m}$ (Table H.6a). The activities of $\mathrm{U}_{2}{ }^{+}$(plotted as the ordinate in Figure 8 ) were then calculated at selected $\mathrm{pH}$ values between 0 and 9 using this P08- activity and the equilibrium constants from WATEQ4 for the dissolution reactions for $\mathrm{H}$-autunite, $\left(\mathrm{UO}_{2}\right)_{3}\left(\mathrm{PO}_{4}\right)_{2}$, and schoepite. The $\mathrm{E}^{\mathrm{H}}$ values were fixed at the selected $\mathrm{pH}$ values by Equation (7).

Figure 8 shows the maximum permissible activities of the aqueous complex $\mathrm{UO}_{2}^{2+}$ as a function of $\mathrm{pH}$ for waters containing the specified activity of $\mathrm{PO}_{4}^{3-}$ and in equilibrium with the solids $\mathrm{H}$-autunite, $\left(\mathrm{UO}_{2}\right)_{3}\left(\mathrm{PO}_{4}\right)_{2}$, and schoepite. For oxidizing uranium-phosphate waters containing no other dissolved constituents, these three solids are the least soluble compounds for this aqueous system. In any water having an initial activity of $10_{2}^{2+}$ that is greater (less negative) than the $U 0_{2}^{2+}$ activities defined by the three solid lines in Figure 8 , the appropriate solid phase (i.e., solubility control) will precipitate until the $U 0_{2}^{2+}$ activity has decreased to that in equilibrium with that solid phase. If the activity of $\mathrm{U}_{2}^{2+}$ in a water is less than those defined by these solubility equilibria, no precipitation of these solid phases will occur. The dashed lines in Figure 8 are metastable extensions of the indicated solubilty equilibria with $\mathrm{H}$-autunite, $\left(\mathrm{UO}_{2}\right)_{3}\left(\mathrm{PO}_{4}\right)_{2}$, and schoepite. The maximum permissible activities of $\mathrm{UO}_{2}^{2+}$ would follow these metastable solubilities (i.e., dashed lines in Figure 8 ) if the precipitation of the equilibrium solid phase (i.e., solid lines in Figure 8 ) was kinetically inhibited.

Based on the thermochemical conditions specified for Figure 8 , the equilibrium solubility controls for uranium for the $\mathrm{pH}$ ranges of 0 to $1.8,1.8$ to 4.7, and 4.7 to 14 are, respectively, $\mathrm{H}$-autunite, $\left(\mathrm{UO}_{2}\right)_{3}\left(\mathrm{PO}_{4}\right)_{2}$, and schoepite. Therefore, if $\log \left\{\mathrm{UO}_{2}^{2+}\right\}=-3.0$ at $\mathrm{pH}=4$, the solid $\left(\mathrm{UO}_{2}\right)_{3}\left(\mathrm{PO}_{4}\right)_{2}$ would precipitate from the water until $\log \left\{\mathrm{U}_{2}^{2}+\right\}$ had decreased to -4.1 . Similarly, if $\log \left\{\mathrm{UO}_{2}^{2+}\right\}=-3.0$ at $\mathrm{pH}=7$, then the mineral schoepite would precipitate and decrease the $\left.\log \left\{U_{0}\right\}^{+}\right\}$to $-P .4$. 
The solubility relations in Figure 8 provide an explanation for the disagreement between the solubility controls identified in the uranium validation study and those determined in the laboratory experiments by Chukhlantsev and Stepanov (1956), Moskvin, Shelyakina, and Perminov (1967), and Muto (1965). If the solubility of $\mathrm{H}$-autunite (starting material) was investigated in aqueous solutions in the $\mathrm{pH}$ range between 2 and 5 [e.g., solutions $A 1, A 3$, and $A 4$ from Moskvin, Shelyakina, and Perminov (1967)], the final concentration of dissolved uranium is that which is in equilibrium with precipitated $\left(\mathrm{UO}_{2}\right)_{3}\left(\mathrm{PO}_{4}\right)_{2}$ and not $\mathrm{H}$-autunite. Moreover, in solubility studies of H-autunite at. $\mathrm{pH}$ values between 1 and 2 [e.g., solutions A5, A10 and A11 from Moskvin, Shelyakina, and Perminov (1967)], the final concentration of dissolved uranium could be controlled simultaneousiy by both $\mathrm{H}$-autunite and $\left(\mathrm{UO}_{2}\right)_{3}\left(\mathrm{PO}_{4}\right)_{2}$.

At $\mathrm{pH}$ values greater than approximately 5, however, the dissolution of $H$-autunite will result in concentrations of dissolved uranium that are in equilibrium with schoepite and not $\mathrm{H}$-autunite or $\left(\mathrm{UO}_{2}\right)_{3}\left(\mathrm{PO}_{4}\right)_{2}$ (Figure 8). Unfortunately, solution A2 from Moskvin, Shelyakina, and Perminov (1967), which is for a dissolution study of $\mathrm{H}$-autunite in a $0.5 \mathrm{~m}$ sodium perchlorate solution, is the only uranium-phosphate water modeled in the validation study that lies in this higher $\mathrm{pH}$ range. The saturation indices calculated for solution A2 with respect to $\mathrm{H}$-autunite, $\left(\mathrm{UO}_{2}\right)_{3}\left(\mathrm{PO}_{4}\right)_{2}$, and schoepite are $-10.15,-2.40$, and 1.22, respectively. Although solution $A 2$ computes to be undersaturated with respect to $\left(\mathrm{UO}_{2}\right)_{3}\left(\mathrm{PO}_{4}\right)_{2}$, the saturation index for this solid is still within the error band $( \pm 2.45)$ for a permissive solubility control. Because schoepite should precipitate readily in a laboratory environment, the calculated oversaturation with respect to schoepite may again indicate that another solid (e.g., Na-autunite or a sodium uranate) is controlling the final concentration of dissolved uranium.

Alternatively, the determined oversaturation of solution A2 from Moskvin, Shelyakina, and Perminov (1967) with respect to schoepite may also indicate that the thermodynamic data in WATEQ4 is not adequate for calculating the aqueous speciation of uranium in aqueous solutions and ground waters at 
$\mathrm{pH}>4.8$. (a) If solution $A 2$ is remodeled with the addition of the U(VI) complexes $\mathrm{UO}_{2}(\mathrm{OH})_{2}$ and $\left(\mathrm{UO}_{2}\right)_{3}(\mathrm{OH})_{7}$ to the WATEQ4 data base, the saturation indices for solution $\mathrm{A} 2$ with respect to $\mathrm{H}$-autunite, $\left(\mathrm{UO}_{2}\right)_{3}\left(\mathrm{PO}_{4}\right)_{2}$, and schoepite are $-10.92,-3.93$, and 0.46 , respectively. Although the saturation index for schoepite is still greater than the equilibrium error band $( \pm 0.27)$, this latter set of saturation indices is in close agreement to the solubility relations depicted in Figure 8. The results from remodeling solution $A 2$ also supports the importance of the neutral and anionic hydroxyl complexes of U(VI), and the need to experimentally verify their existence.

The results of this validation study with respect to the uranyl phosphate solids suggest that the solubility controls for dissolved uranium may have been incorrectly. identified in the experimental studies by Chukhlantsev and Stepanov (1956), Moskvin, Shelyakina, and Perminov (1967), and Muto (1965). This problem will have an adverse effect on the thermodynamic data derived from these solubility experiments for the uranyl phosphate solids and complexes. (b) The magnitude of these effects, however, cannot be assessed at this time until additional solubility data become available for uranyl phosphate solids. These solubility data should include characterization of the solids in equilibrium with the final solutions, and analytical determinations of $\mathrm{pH}$ and dissolved concentrations of uranium, phosphate, and other constituents (e.g., sodium) in the final solutions.

URANINITE $\left(\mathrm{UO}_{2}\right)$ AND COFFINITE $\left(\mathrm{USiO}_{4}\right)$

Ground-water analyses (Tables $H .9 \mathrm{~b}$ and $H .10 \mathrm{~b}$ ) were selected from tield studies for a validation study of WATEQ4 with respect to natural ground waters and solubility controls by the U(IV) minerals uraninite and coffinite. The ground-water samples of Chatham, Wanty, and Langmuir (1981) were collected from known localities of uraninite $\left(\mathrm{UO}_{2}\right)$ and coffinite $\left(\mathrm{USiO}_{4}\right)$ mineralization; those of Păces (1969) were associated with uraninite mineralization (see description

(a) See discussions in Appendix $B$ with respect to mineral equilibria with U(VI) hydroxides.

(b) See derivation for thermodynamic data of uranyl phosphate solids and complexes in Langmuir (1978). 
of these references in Appendix H). Except for water analysis No. 30 from Păces (1969), for which the uraninite saturation index is -1.42 , all of the selected ground waters compute to be two to four orders of magnitude oversaturated with respect to uraninite (Figure 9 ).

Because the accuracy of modeling solubility controls for dissolved U(IV) may depend to a great degree on the values accepted for the redox potential, the ground waters from Chatham, Wanty, and Langmuir (1981) and Păces (1969) were remodeled assuming an uncertainty of $\pm 50 \mathrm{mV}$ in their quoted $\mathrm{EPt}_{\mathrm{t}}$ values. This uncertainty is a liberal estimate, based on the field measurements of E $\mathrm{P}_{t}$ described by. Nordstrom, Jenne, and Ball (1979) and the $\pm 10 \mathrm{mV}$ uncertainty quoted by Chatham, Warty, and Langmuir (1981). Except for one ground water analysis, the $\pm 50 \mathrm{mV}$ error brackets determined for the uraninite saturation indices in the ground waters from Chatham, Wanty, and Langmuir (1981) were less than the width of the plotting symbols (Figure 9). A decrease of $50 \mathrm{mV}$ in the redox potential was sufficient to bring ground-water analysis No. 30 from Paces (1969) into apparent equilibrium with uraninite. The other waters maintained their calculated oversaturation with respect to uraninite.

Coffinite $\left(\mathrm{USiO}_{4}\right)$ has also been identified at the locations for the water analyses selected from Chathain, Warly, and Langmuir (1981). Thesc ground waters, however, compute to be oversaturated with respect to coffinite (Table H.9b). As with the data in Figure 9, saturation indices for coffinite were not significantly changed by a $\pm 50 \mathrm{mV}$ uncertainty in the redox potential of the selected water analyses.

The calculated oversaturation of these waters with respect to uraninite and coffinite cannot be readily explained at this tille. This apparent oversaturation in ground waters ill contact with known uraninite mineralization has been noted by other investigators. Chatham, Wanty, and Langmuir (1981) used a version of the WATEQF geochemical model to interpret the geochemistry of ground waters collected in their field study. They explained the apparent oversaturation of these waters with respect to uraninite and coffinite as an indication that these minerals are currently precipitating as more soluble amorphic forms of $\mathrm{UO}_{2}$ and $\mathrm{USiO}_{4}$. 'They proposed that these phases then alter 


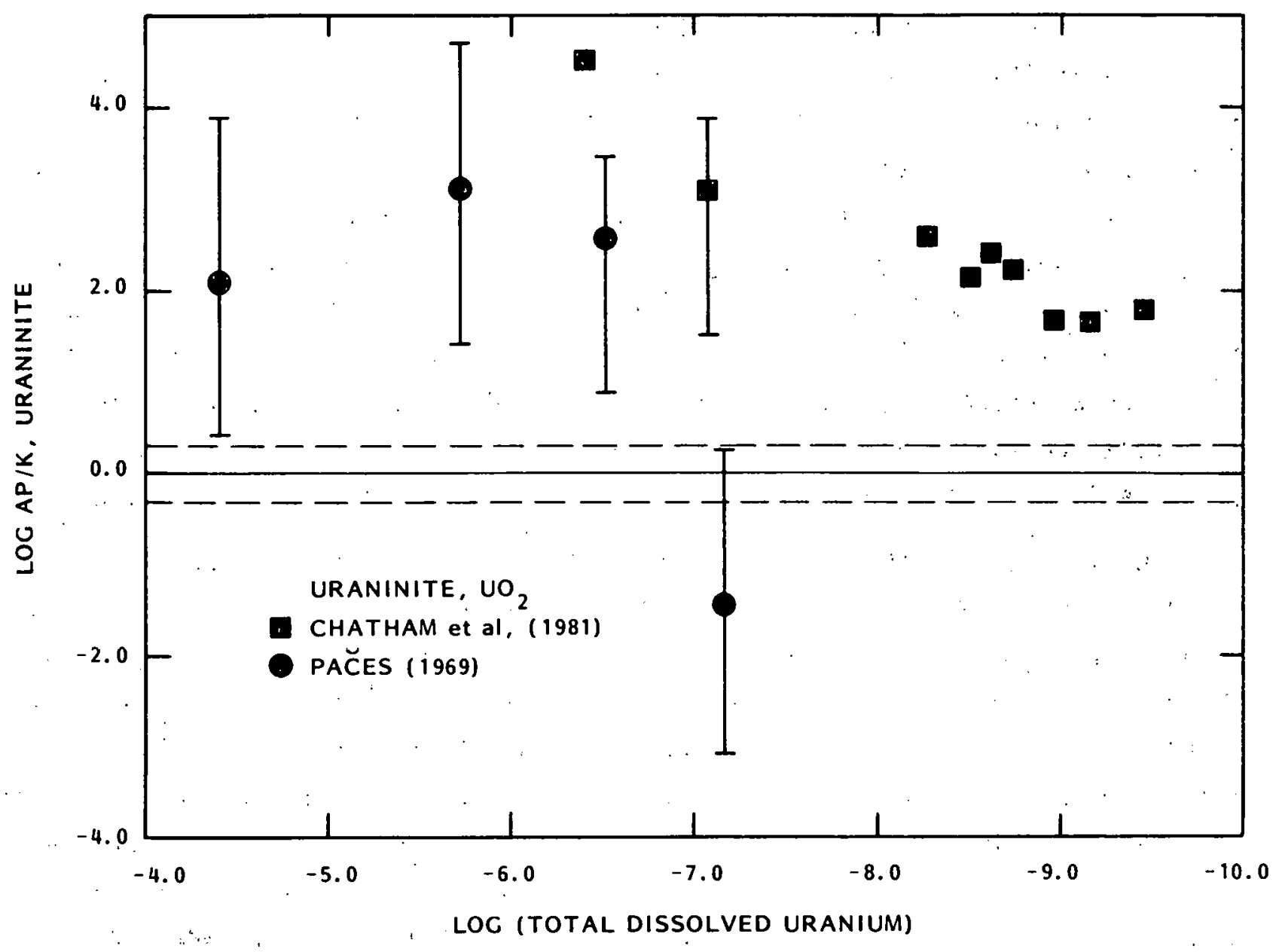

FIGURE 9. Uraninite Saturation Indices Plotted Versus Total Concentration of Dissolved Uranium [The error brackets represent the maximum and minimum indices calculated from a $\pm 50 \mathrm{mV}$ uncertainty in the redox potential of those waters.]

with time to crystalline uraninite and coffinite that are representative of the thermodynamic data stored in the geochemical model. Lueck (1978) also used a version of the geochemical model WATEQF to calculate saturation indices for ground waters from uraninite deposits in Wyoming and Texas. His results, which are also described in Runnells et al. (1980) and Runnells and Lindberg (1981), similarly indicate that those waters are apparently several orders of magnitude oversaturated with respect to uraninite and coffinite. Causes for the calculated oversaturation were not discussed. 
The saturation indices for $\mathrm{UO}_{2}(\mathrm{am})$, (a) $\mathrm{U}_{4} \mathrm{O}_{9}(\mathrm{c})$, and $\mathrm{U}_{3} \mathrm{O}_{8}(\mathrm{c})$ are also listed in Tables H.9b and H.10b, respectively, for the waters from Chatham, Wanty, and Langmuir (1981) and Păces (1969). The equilibrium error bands at $25^{\circ} \mathrm{C}$ are $0.05,0.17$, and 1.06 for $\mathrm{UO}_{2}(\mathrm{am}), \mathrm{U}_{4} \mathrm{O}_{9}(\mathrm{c})$, and $\mathrm{U}_{3} \mathrm{O}_{8}(\mathrm{c})$, respectively. None of the selected ground waters calculate to be in equilibrium with these uranium oxides. The $\mathrm{U}_{4} \mathrm{O}_{9}$ saturation index for water sample T35 from Chatham, Wanty, and Langmuir (1981) is -0.19 , which is close to the error band for permissive equilibrium with that solid. All of these ground waters are signifi-. cantly undersaturated ( 1 to 8 orders of magnitude) with respect to $\mathrm{UO}_{2}(\mathrm{am})$. Therefore, based on the available thermodynamic data, the solubility controls for dissolved uranium in these reducing ground waters cannot be identified.

An alternative set of thermodynamic data for the aqueous complexes $\mathrm{U}(\mathrm{OH})_{2}^{2+}, \mathrm{U}(\mathrm{OH})_{3}^{+}, \mathrm{U}(\mathrm{OH})_{4}^{0}$, and $\mathrm{U}(\mathrm{OH})_{5}$, which were derived from the $\mathrm{UO}_{2}$ solublity data of Tremaine et a1. (1981) (see Appendix C), were used to remodel the water analyses from Chatham, Wanty, and Langmuir (1981) and Păces (1969). The calculated oversaturation for these ground waters with respect to uraninite and coffinite, however, was approximately two orders of magnitude greater than that determined solely using thermodynamic data in Langmuir (1978). The increased apparent oversaturation is a result of the solubility determined by Tremaine et al. (1981) for crystalline $\mathrm{UO}_{2}$, which is approximately two orders lower than that obtained by Gayer and Leider (1957).

Figure 10 shows the maximum concentration of dissolved uranium calculated to be in equilibrium with crystalline $\mathrm{UO}_{2}$ as a function of $\mathrm{pH}$ in reducing uranium waters free of complexing ligands other than hydroxyl. These solubility calculations were made using the thermodynamic data for U(IV) hydroxyl complexes in Langmuir (1978) and those derived in this study (Appendix C) from the solubility data of Tremaine et al. (1981). The $E^{H}$, values of the waters. were fixed as a function of $\mathrm{pH}$ by the empirical relation:

$$
\mathrm{pE}+\mathrm{pH}=1.9
$$

(a) The abbreviations am and $c$ are descriptors for amorphous and crystalline solids, respectively. 


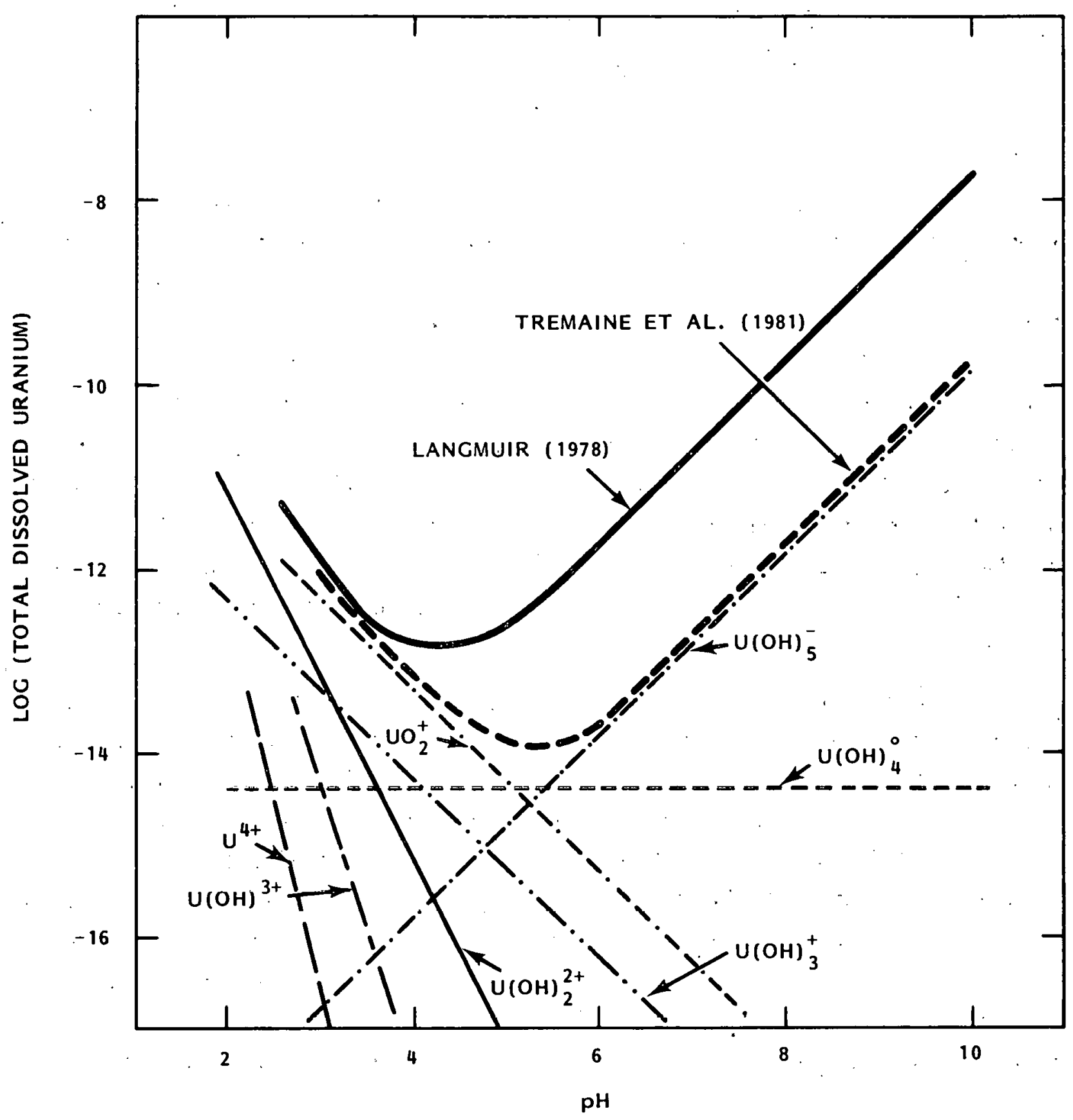

FIGURE 10. Maximum Concentrations of Dissolved Uranium in Equilibrium at $25^{\circ} \mathrm{C}$ with Uraninite $\left(\mathrm{UO}_{2}\right)$ [Thick solid and dashed curves represent maximum uranium concentrations calculated from thermodynamic data for U(IV) hydroxyl complexes from Langmuir (1978) and those derived from solubility data in Tremaine et al. (1981). Mass distributions of aqueous $U(V)$ and U(IV) hydroxyl complexes are snown as thinner solid and dashed curves.] 
This relationship was selected for this example because it corresponds to the $\mathrm{E}^{\mathrm{H}}$ and $\mathrm{pH}$ conditions estimated by Jacobs and Apted (1981) for ground water in the Umtanum Flow of the Grande Ronde Basalt on the Hanford Site in eastern Washington. (a)

Above $\mathrm{pH} \simeq 5$ (Figure 10 ), the calculated uraninite solubilities using the thermodynamic data of Langmuir (1978) as well as Tremaine et al. (1981) differ by two orders of magnitude. This accounts for the larger uraninite and coffinite saturation indices calculated for the waters from Chatham, Wanty, and Langmuir (1981) and Păces (1969) when modeled with the thermodynamic data derived from Tremaine et al. (1981). The mass distribution of the $U(V)$ and U(IV) hydroxyl complexes [based on thermodynamic data derived from Tremaine et al. (1981)] have been superimposed on figure 10. The complexes $\mathrm{UO}_{2}^{+}, \mathrm{U}(\mathrm{OH})_{4}^{0}$, and $\mathrm{U}(\mathrm{UH})_{5}$ dominate the computed speciation over the $\mathrm{pH}$ ranges of 2.4 to 5.2 , 5.2 to 5.5 , and 5.5 to 14 , respectively. Figure 10 clearly shows the importance of the $U(I V)$ hydroxyl complex $U(O H) \overline{5}$ in reducing ground waters above $\mathrm{pH} \simeq 5$.

Resolution of the apparent discrepancy between the modeling results and the uranium solubility controls identified at the field site studies by Chatham, Wanty, and Langmuir (1981) and Păces (1969) may require further characterization of the uranium mineralogy at the sites of the ground-water samples and or laboratory studies of unoxidized samples of the ore itself. The discrepancy in the solubility data for uraninite needs to be resolved. Moreover, the avallable laboratory and field studies of dissolved U(IV) in reducing waters having measured $\mathrm{E}^{\mathrm{H}}$ and $\mathrm{pH}$ values are inadequate for an evaluation of either the solubility data for U(IV) solids, including uraninite, or of the hydroxyl complexes of U(IV) $\left[\right.$ e.g., $\left.U(\mathrm{OH})_{5}\right]$ that have been derived from solubility data for $\mathrm{UO}_{2}$.

(a) The Hanford Site is one of the sites being investigated as a potential repository for high level nuclear wastes. 


\section{REFERENCES}

Allard, B., H. Kipatsi, and J. 0. Liljenzin. 1980. "Expected Species of Uranium, Neptunium and Plutonium in Neutral Aqueous Solutions." J. Inorg. Nucl. 42:1015-1027.

Baes, Jr., C. F., and R. E. Mesmer. 1976. The Hydrolysis of Cations. WileyInterscience, New York.

Ball, J. W., E. A. Jenne, and M. W. Cantrell. 1981. WATEQ3: A Geochemical Model with Uranium Added. U.S. Geological Survey, Open-File Report 81-1183, Menlo Park, California

Ball, J.W., D. K. Nordstrom, and E. A. Jenne. 1980. Additional and Revised Thermochemical Data and Computer Code for WATEQ2 - A Computerized Chemical Model for Trace and Major Element Speciation and Mineral Equilibria of. Natural Waters. U.S. Geol. Survey, Water-Resources Investigations 78-116, Menlo Park, California

Bates, R. L., and J. A. Jackson, eds. 1980. Glossary of Geology. American Geological Institute, Falls Church, Virginia.

Beck, M. T. 1970. Chemistry of Complex Equilibria. Van Nostrand Reinhold, New York.

Brush, L. H. 1980. "Solubility of Some Phases in the System $\mathrm{UO}_{3}-\mathrm{Na}_{2} \mathrm{O}-\mathrm{H}_{2} \mathrm{O}$ in Aqueous Solutions at $60^{\circ} \mathrm{C}$ and $90^{\circ} \mathrm{C} . " \mathrm{Ph} . \mathrm{D}$. Dissertation, Harvard Oniversity, Cambridge, Massachusetts.

Burington, R. S. 1961. Handbook of Mathematical Tables and Formulas. McGrawHill Book Company, New York.

Bullwinkel, E. P. 1954. The Chemistry of Uranium in Carbonate Solutions. U.S. Atom. Energy Comm. RM0-2614, Washington, D.C.

Chase, M. W., J. L. Curnutt, H. Prophet, R. A. McDonald, and A. N. Syverud. 1975. "JANAF Thermochemical Tables, 1975 Supplement." J.Physical.Chemical Ref. Data 4:1-175.

Chatham, J. R., R. B. Wanty, and D. Langmuir. 1981. Groundwater Prospecting for Sandstone-Type Uranium Deposits: The Merits of Mineral-Solution Equilibria Versus Single Element Tracer Methods. Final Report. U.S. Department of Energy Report GJ0 79-360-E, Grand Junction, Colorado.

Chukhlantsev, V. G., and K. V. Alyamovskaya. 1961. "Solubility Product of Uranyl, Beryllium and Cerium Phosphates." Izvest. VUZ Khim. Tekhnol. $4: 359-363$. 
Chukhlantsev, V. G., and S. I. Stepanov. 1956. "Solubility of Uranyl and Thorium Phosphates." Russ. J. Inorg. Chem. 1:135-141.

Ciavatta, L., D. Ferri, I. Grenthe, and F. Salvatore. 1981. "The First Acidification Step of the tris(carbonato)dioxouranate(VI) Ion, $\mathrm{UO}_{2}\left(\mathrm{CO}_{3}\right)_{3}^{4-}$." Inorg. Chem. 20:463-467.

CODATA Task Group. 1976. "CODATA Recommended Key Values for Thermodynamics. 1975. J. Chem. Thermodynamics 8:603-605.

Cordfunke, E. H. P., and P. A. P. O'Hare. 1978. The Chemical Thermodynamics of Actinide Elements and Compounds. Part 3. Miscellaneous Actinide Compounds. International Atomic Energy Agency, Vienna, Austria.

Cordfunke, E. H. P., R. P. Muis, W. Ouweltjes; H. F. Flotow, and P. A. G. 0 'Hare. 1982. "The Therriudynamic Properties of $\mathrm{Na}_{2} \mathrm{UO}_{4}, \mathrm{Na}_{2} \mathrm{U}_{2} \mathrm{O} \%$ and $\mathrm{NaUO}_{3} \cdot \mathrm{J}$. Chem. Thermodynamics 14:313-322.

Dongarra, G., and D. Langmuir. 1980. "The Stability of $\mathrm{UO}_{2} \mathrm{OH}^{+}$and $\mathrm{UO}_{2}\left[\mathrm{HPO}_{4}\right]_{2}^{2-}$ Complexes at $25^{\circ} \mathrm{C} . "$ Geochim. Cosmo. Acta 44:1747-1751.

Ferri, D., I. Grenthe, and F. Salvatore. 1981. "Dioxouranium(VI) Carbonate Complexes in Neutral and Alkaline Solutions." Acta Chem. Scand. A35:165-168.

Garrels, R. M., and C. L. Christ. 1965. Solutions, Minerals, and Equilibria. Harper and Row, New York.

Gayer; K. H., and H. Leider. 1955. "The Solubility of Uranium Trioxide, $\mathrm{UO}_{3}$ $\mathrm{H}_{2} \mathrm{O}$, in Solutions of Sodium Hydroxide and Perchloric Acid at $25^{\circ} \mathrm{C}$." J. Amer. Chem. Soc. 77:1448-1450.

Gayer, K. H., and H. Lelder. 1957. "The Solubtlity of Uranium(IV) Hydruxide in Solutions of Sodium Hydroxide and PerchlorlC Acld at $25^{\circ} \mathrm{C} . "$ Can. J. Chem. $35: 5-7$.

Holland, H. D., and L. H. Brush. 1978. "Uranium Oxides in Ores and Spent Fuels:" In Proceedings of the Conference on High-Level Radioactive Solid Waste Forms, ed. L. A. Casey, pp. 597-615, NUREG/CP-005, Washington, D.C.

Hostetler, P. B., and R. M. Garrels. 1962. "Transportation and Precipitation of Uranium and Vanadium at Low Temperatures, with Special Reference to Sandstone-Type Uranium Deposits." Econ. Geol. 57:137-167.

Jacobs, G. K., and M. J. Apted. 1981. "Eh-pH Conditions for Groundwater at the Hanford Site, Washington: Implications for Radionuclide Solubility in a Nuclear Waste Repository Located in Basalt." EOS (Amer. Geophysical Union), 62:1065 (Abstract). 
Jenne, E. A., J. W. Ball, J. M. Burchard, D. V. Vivit, and J. H. Barks. 1980. "Geochemical Modeling: Apparent Solubility Controls of Ba, $\mathrm{Zn}, \mathrm{Cd}$, $\mathrm{Pb}$, and $\mathrm{F}$ in Waters of the Missouri Tri-State Mining Area." In Trace Substances in Environmental Health - XIV, ed. D. D. Hemphill, pp. 353-361, University of Missouri, Columbia, Missouri.

Krupka, K. M., and E. A. Jenne. 1982. WATEQ3 Geochemical Model: Thermodynamic Data for Several Additional Solids. PNL-4276, Pacific Northwest Laboratory, Richland, Washington.

Langmuir, D. 1978. "Uranium Solution-Mineral Equilibria at Low Temperatures with Applications to Sedimentary Ore Deposits." Geochim. Cosmo. Acta 42:547569.

Langmuir, D. 1979. "Techniques of Estimating Thermodynamic Properties for Some Aqueous Comp.lexes of Geochemical Interest." In Chemical Modeling in Aqueous Systems, ed. E. A. Jenne, pp. 353-387. Amer. Chem. Soc. Symp. Series 93; Washington, D.C.

Langmuir, D., and J. R. Chatham. 1980. "Groundwater Prospecting for Sandstone-Type Uranium Deposits: A Preliminary Comparison of the Merits of Mineral-Solution Equilibria, and Single-Element Tracer Methods." J.Geochem. Explor. 13:201-219.

Latimer, W. M. 1952. The Oxidation States of the Elements and Their Potentials in Aqueous Solutions. 2nd ed. Prentice-Hall, New York.

Lemire, R. L., and P. R. Tremaine. 1980. "Uranium and Plutonium Equilibria in Aqueous Solutions to $200^{\circ} \mathrm{C} . " \mathrm{~J}$. Chem. Eng. Data 25:361-370.

Lewis, G. N., and M. Randa11. 1961. Thermodynamics. 2nd ed. revised by K. S. Pitzer and L. Brewer, McGraw-Hill, New York.

Lindemer, T. B., T. M. Besmann, and C. E. Johnson. 1981. "Thermodynamic Review and Calculations-Alkali-Metal Oxide Systems with Nuclear Fuels, Fission Products, and Structural Materials." J. Nucl. Materials 100:178-226.

Lindsay, W. L. 1979. Chemical Equilibria in Soils. John Wiley and Sons, New York.

Lueck, S. L. 1978. "Computer Modelling of Uranium Species in Natural Waters." M.Sc. Thesis, University of Colorado, Boulder, Colorado.

Mann, A. W. 1974a. Calculated Solubilittes of Some Uranium and Vanadium Compounds in Pure and Carbonated Waters, as a Function of pH. CSIRO Minerals Res. Labs., Div. of Mineralugy, Rept. No. FP. 6, Wembley, Australia.

Mann, A. W. 1974b. Chemical Ore Genesis Models for the Precipitation of Carnotite in Calcrete. CSIRO Minerals Res. Labs., Div. of Mineralogy, Rept. No. FP. 7, Wembley, Australia. 
Maya, L. and G. M. Begun. 1981. "A Raman Spectroscopy Study of Hydroxo and Carbonato Species of the Uranyl (VI) Ion." J. Inorg. Nucl. Chem.

$43: 2827-2832$.

Miller, L. J. 1958. "The Chemical Environment of Pitchblende." Econ. Geol: $53: 521-545$.

Moskvin, A. I., A. M. Shelyakina, and P. S. Perminov. 1967. "Solubility Product of Uranyl Phosphate and the Composition and Dissociation Constants of Uranyl Phosphato-Complexes." Russ. J. Inorg. Chem. 12:1756-1760.

Muto, T. 1965. "Thermochemical Stability of Ningyoite." Mineral. J. $4: 245-274$.

Naumov, G. B., B. N. Ryzhenko, and 1. L. Knodakovsky. 1974. Handbook of Thermodyrlamic Dalá. U.J. Geological Survey WRD-71-001, translation, NTIS-PB226 722/AS, National Technical Information Service, Springfield, Virginia.

Nikitin, A. A., Z. I. Sergeeva, I. L. Khodakovsky, and G. B. Naumov. 1972. "Uranyl Hydrolysis in a Hydrothermal Region." Geoknimiya 3:297-307.

Nordstrom, D. K., E. A. Jenne, and J. W. Ball. 1979. "Redox Equilibria of Iron in Acid Mine Waters." In Chemical Modeling in Aqueous Systems, ed. E. A. Jenne, pp. 51-80. Amer. Chem. Soc. Symp. Series 93, Washington, D.C.

Nordstrom, D. K., L. N. Plummer, T. M. L. Wigley, T. J, Wolery, J. W. Ball, E. A. Jenne, et al. 1979. "A Comparison of Computerized Cnemical Models for Equilibrium Calculations in Aqueous Systems." In Cnemical Modeling in Aqueous Systems, ed. E. A. Jenne, pp. 815-835. Amer. Chem. Soc. Symp. Series 93, Wasnington, D.C.

Păces, T. 1969. "Chemical Equilibria and Zoning of Subsurface Water from lachymov Ore Deposit, Czechoslovakia." Geochem. Cosmo. Acta 33:591-609.

Paquette, J., and R. J. Lemire. 1981. "A Description of the Chemistry of Aqueous Solutions of Uranium and Plutonium to $200^{\circ} \mathrm{C}$ Using Potential-pH Diagrams." Nucl. Sci. Eng. 79:26-48.

Parker, V. B., D. D. Wagman, and W. H. Evans. 1971. "Selected Values of Cnemical Thermodynamic Properties. Tables for the alkaline earth elements (elements 92 through 97 in the standard order of arranyement)." U.S. Natl. Bur. Standards Tech. Nule 270-6, U.S. Government Printing Office, Washington, D.C.

Relyea, J. F., and R. J. Silva. 1981. Application of a Site-Binding, Electrical, Double-Layer Model to Nuclear Waste Disposal. PNL-3898, Pacific Northwest Laboratory, Richland, Washington. 
Robie, R. A., P. M. Bethke, and K. M. Beardsley. 1967. "Selected X-ray Crystallographic Data, Molar Volumes, and Densities of Minerals and Related Substances." U.S. Geol. Survey Bul1. 1248, U.S. Government Printing Office, Washington, DC.

Robie, R. A., B. S. Hemingway, and J. R. Fisher. 1978. "Thermodynamic Properties of Minerals and Related Substances at $298.15 \mathrm{~K}$ and 1 bar $\left(10^{5}\right.$ Pascals) Pressure and at Higher Temperatures." U.S. Geol. Survey Bull. 1452, reprinted with corrections 1979, U.S. Government Printing Office, Washington, D.C.

Robins, R. G. 1966. "Hydrolysis of Uranyl Nitrate Solutions at Elevated Temperatures." J. Inorg. Nucl. Cnem. 28:119-123.

Runnells, D. D., and R. D. Lindberg. 1981. "Hydrogeochemical-Exploration for Uranium Ore Deposits: Use of the Computer Model WATEQFC." J. Geochemical Explor. 15:37-50.

Runnel1s, D. D., R. D. Lindberg, S. L. Lueck, and. G. Markos. 1980. "Applications of Computer Modelling to the Genesis, Exploration, and In-situ Mining of Uranium and Vanadium Deposits.: In Proceedings of Symposium on the Grants Mineral Belt, ed. C. Rautmann, Memoir 38, New Mexico Bureau of Mines and Mineral Resources, pp. 355-367, Socorro, New Mexico.

Sergeyeva, E. I., A. A. Nikitin, I. L. Khodakovskiy, and G. B. Naumov. 1972. "Experimental Investigation of Equilibria in the System $\mathrm{UO}_{3}-\mathrm{CO}_{2}-\mathrm{H}_{2} \mathrm{O}$ in 25-200 ${ }^{\circ} \mathrm{C}$ Temperature Interval." Geochem. Inter. 9:900-910.

Smith, R. M., and A. E. Martell. 1976. Critical Stability Constants. Volume 4: Inorganic Complexes. Plenum Press, New York.

Sutton, J. 1949. "The Hydrolysis of the Uranyl Ion. Part I." J. Cnem. Soc., \$275-\$286.

Sylva, R. N., and M. R. Davidson. 1979. "The Hydrolysis of Metal Ions. Part 2. Dioxouranium(VI).". J. Chem. Soc., Dalton Trans., 465-471.

Thorstenson, C. 1982. "The Concept of Electron Activity and the Redox Potential of Aqueous Solutions." Paper presented at the 183rd American Cnemical Society National Meeting, March 28-April 2, 1982, Las Vegas, Nevada.

Tremaine, P. R., J. D. Chem, G. J. Wallace, and W. A. Boivin. 1981. "Solubility of Uranium (IV) Oxide in Alkaline Aqueous Solutions to $300^{\circ} \mathrm{C} . "$ 1. Solution Chem. 10:221-230.

Truesde11, A. H., and B. F. Jones. 1974. "WATEQ, A Computer Program for Calculating Chemical Equilibria of Natural Waters." J. Res. U.S. Geol. Survey 2:233-248. 
Tsymbal, C. 1969. "Contribution to the Solution Chemistry of Uranium (VI)." Nucl. Sci. Abs. 23(24):abs. 49767.

Wagman, D. D., W. H. Evans, V. B. Parker, I. Halow, S. M. Bailey, and R. H. Schumm. 1968. "Selected Values of Chemical Thermodynamic Properties. Tables for the first thirty-four elements in the standard order arrangement." U.S. Natl. Bur. Standards Tech. Note 270-3, U.S. Government Printing Office, Washington, D.C.

Wagman, D. D., W. H. Evans, V. B. Parker, I. Halow, S. M. Bailey, and R. H. Schumm. 1969. "Selected Values of Chemical Thermodynamic Properties. Tables for elements 35 through 53 in the standard order of arrangement." U.S. Nat1. Bur. Standards Tech. Note 270-4, U.S. Government Printing Office, Washington, D.C.

Wagman, U. U., W. H. Evans, V. B. Parkerer, R. H. Schumim, and R. L. Hutall. 1981. "Selected Values of Chemical Thermodynamic Properties. Compounds of Uranium, Protactinium, Thorium, Actinium, and the Alkali Metals." U.S. Natl. Bur. Standards Tech. Note 270-8, U.S. Government Printing Office, Washington, D.C.

Wamser, C. A., J. Belle, E. Bernsohn, and B. Williamson. 1952. "The Constitution of the Uranates of Sodium." J. Amer. Chem. Soc. 74:10201022.

Wanty, R. B., D. Langmuir, and J. R. Chatham. 1981. Groundwater Prospecting for Sandstone-Type Uranium Deposits: The Merits of Mineral-Solution

Equilibria Versus Single Element Tracer Methods. Volume II. U.S. Department of Energy Report GJO 79-360-E, Grand Junction, Colorado.

Westall, J. C., J. L. Zachary, and F. M. M. Morel. 1976. MINEQL, A Computer Equilibrium Composition of Aqueous Systems. Tech. Note 18, Dept. Civil Eng., Massachusetts Institute of Technology, Cambridge, Massachusetts. 


\section{APPENDIX A}

CORRECTIONS TO WATEQ3 AND ITS DOCUMENTATION 
APPENDIX A

\section{CORRECTIONS TO WATEQ3 AND ITS DOCUMENTATION}

Before the WATEQ4 model was completed at Pacific Northwest Laboratory, the WATEQ3 geochemical model (Ball, Jenne, and Cantrell 1981) was used. However, two problems, detailed in Felmy and Jenne, (a) were encountered when WATEQ3 was used to model solution analyses from the uranium validation study. First, uranium-containing waters could not be modeled without including fluoride and chloride in the solution analyses. Failure to include even a trivial concentration of fluoride and chloride resulted in a program error and nonconvergence of the calculated speciation. This problem was due to an error in the section of the WATEQ3 code that calculates the speciation of uranium. This code error was corrected by A. R. Felmy (Pacific Northwest Laboratory).

The second problem involved the convergence of the calculated speciation by WATEQ3, which is based only on the mass totals of major anionic constituents, such as dissolved carbonate, sulfate, or nitrate. As a result, if a solution analysis does not contain any major anionic constituents, there is, in effect, no check of convergence for speciation. This is generaliy a problem only when a polynuclear species $\left[\mathrm{e} . \mathrm{g} .,\left(\mathrm{UO}_{2}\right)_{3}(\mathrm{OH})_{5}^{+}\right.$in basic, carbonate-free uranium solutions] is a significant fraction of the mass total.

Because aqueous speciation in WATEQ4 is based on convergence of the mass balance equations for both the cationic and anionic components, all modeling results discussed in this present report are based solely on WATEQ4. With the development of the new WATEQ4 model, no attempts were made to rectify the convergence limitations in WATEQ3.

As a check of the internal consistency of the uranium thermodynamic data of Langmuir (1978), Ball, Jenne, and Cantrell (1981, Table 1) calculated $\Delta G_{r, 298}^{0}$ and $\log K_{r, 298}^{0}$ values from both Equations (2) and (3). Because

(a) Felmy, A. R. and E. A. Jenne. (In preparation) Documentation for the Speciation-Solubility Model WATEQ4. PNL report, Pacific Northwest Laboratory, Richland, Washington. 


$$
\Delta G_{f}^{Q}, 298=\Delta H_{f, 298}^{O}-298.15 \Delta S_{298}^{0},
$$

the resulting $\log K_{r, 298}^{0}$ calculated from the two equations should be equivalent. However, the pairs of $\log \mathrm{K}_{r, 298}^{0}$ values calculated for the species $\mathrm{U}^{3+}$ and $\mathrm{UO}_{2}^{+}$and solids $\mathrm{U}_{4} \mathrm{O}_{9}(\mathrm{c}), \mathrm{U}_{3} \mathrm{O}_{8}(\mathrm{c})$, and $\left(\mathrm{UO}_{2}\right)_{3}\left(\mathrm{PO}_{4}\right)_{2}(\mathrm{c})$ differed from each other by several orders of magnitude. The discrepancies noted for $\mathrm{U}^{3+}, \mathrm{UO}_{2}^{+}$, $\mathrm{U}_{4} \mathrm{O}_{9}(\mathrm{c})$, and $\mathrm{U}_{3} \mathrm{O}_{8}(\mathrm{c})$ are apparently due to a computational oversight wherein $\mathrm{S}_{298}$ for the electron was omitted in calculating $\log \mathrm{K}_{r, 298}^{0}$ with Equation (3) for their hydrolysis reactions (Ball, Jenne, and Cantrell 1981). The hydrolysis reactions for these four uranium solids contain two valence states of uranium, and thus have an electron as a reaction constituent. The $S_{298}^{0}$ for the electron $\left(e^{-}\right)$is equal to $0.5 \times S_{29 B}^{0}$ for $\mathrm{H}_{2}(g)$, by definition of standard state, from the reaction

$$
0.5 H_{2}(g)=H^{+}+e^{-} \text {. }
$$

Lindsay (1979) gives $S_{298}^{0}=15.603 \mathrm{cal} \mathrm{mol}^{-1} \mathrm{~K}^{-1}$ for the electron. By convention, $\Delta G_{f, 298}^{0}, \Delta H_{f, 298}^{0}$, and $S_{298}^{0}$ for $H^{+}$are zero. Therefore, if a reaction contains an electron as a constituent, $S_{298}^{0}$ for $\mathrm{e}^{-}$must be included in the derivation of $\log k_{r, 298}^{0}$ values from Equation (3).

The discrepancies noted for the $\log \mathrm{K}_{\mathrm{r}, 298}^{0}$ values for $\left(\mathrm{UO}_{2}\right)_{3}\left(\mathrm{PO}_{4}\right)_{2}(\mathrm{c})$ (Ball, Jenne, and Cantrell 1981) are discussed in Appendix E. 
APPENDIX B

U(VI) HYDROXYL SPECIES 


\section{APPENDIX B}

\section{U(VI) HYDROXYL SPECIES}

Neutral and anionic hydroxyl complexes for U(VI) were not included in Langmuir (1978), who had relied on the review of U(VI)-hydroxyl complexes by Baes and Mesmer (1976). However, inclusion of species such as $\mathrm{UO}_{2}(\mathrm{OH}) 2$ and $\left(\mathrm{UO}_{2}\right)_{3}(\mathrm{OH})_{\overline{7}}$, which have been reported in recent reviews of thermodynamic data, will have a significant effect on the speciation of dissolved U(VI) at $\mathrm{pH}>6$. Lemire and Tremaine (1980) include thermodynamic data for the species $\mathrm{UO}_{2}(\mathrm{OH})_{2}^{\mathrm{O}(\mathrm{a})}$ and $\left(\mathrm{UO}_{2}\right)_{3}(\mathrm{OH})_{7}$, which they calculated from the studies of Nikitin et al. (1972) and Sutton (1949), respectively. Allard, Kipatsi, and Liljenzin (1980), using extrapolation methods for the step-wise stability constants of $U(V I)$. hydrolysis products, estimated equilibrium constants for the mononuclear complexes $\mathrm{UO}_{2}(\mathrm{OH})_{2}^{0}$ and $\mathrm{UO}_{2}(\mathrm{OH})_{3}^{-}$. Based on the calculations of Allard, Kipatsi, and Liljenzin (1980), $\mathrm{UO}_{2}(\mathrm{OH})_{2}^{0}$ and $\mathrm{UO}_{2}(\mathrm{OH})_{3}$ dominate the speciation of $\mathrm{U}(\mathrm{VI})$ in a pure, carbonate-free aqueous system in equilibrium with a U(VI) hydroxide solid under alklaine conditions at $25^{\circ} \mathrm{C}$. The $E^{H}-\mathrm{pH}$ diagrams calculated at selected temperatures between 25 and $200^{\circ} \mathrm{C}$ by Pacquette and Lemire (1981) similarly show the dominance of the neutral and anionic hydrolysis species for U(VI) under alkaline; oxidizing conditions. Moreover, because $\left(\mathrm{UO}_{2}\right)_{3}(\mathrm{OH})_{7}$ (Lemire and Tremaine 1980) is a polynuclear species, the size of its stability field, relative to the other hydrolysis species, will be a function of the total concentration of dissolved uranium.

Both sorption and Raman spectroscopic measurements support the existence of neutral anionic hydrolysis species for U(VI). Sorption experiments reported

(a) The recent National Bureau of Standards (NBS) Technical Note 270-8 by Wagman et al. (1981), which contains thermodynamic data for gases, aqueous species, and solids of uranium, also includes data for the species $\mathrm{UO}_{2}(\mathrm{OH}) 2$. Without explanation, Wagman et al. (1981) have tabulated data for only two U(VI) hydroxyl complexes, $\mathrm{UO}_{2}^{+}$and $\mathrm{UO}_{2}\left(\mathrm{OH}_{2}\right)_{2}^{0}$, and have not included data for species such as $\mathrm{UO}_{2} \mathrm{OH}^{+},\left(\mathrm{UO}_{2}\right)_{2}(\mathrm{OH})_{2}^{2+}$, and $\left(\mathrm{UO}_{2}\right)_{3}(\mathrm{OH})_{5}^{+}$ listed in Langmuir (1978). 
in Relyea and Silva (1981) for U(VI) sorption on powdered $\mathrm{SiO}_{2}$ (Mil-U-sil®) support the existence of one or more additional hydroxyl complexes at high $\mathrm{pH}$ conditions. In Silva's sorption experiments using $10^{-4} \mathrm{M} \mathrm{U0}_{2}^{2+}$ in four different $\mathrm{NaCl}$ solutions (0.001 to $1 \mathrm{M} \mathrm{NaCl})$, Relyea and Silva (1981) assumed that the concentration of dissolved $U(V I)$ was controlled primarily by the precipitation of $\mathrm{UO}_{2}(\mathrm{OH})_{2}(\mathrm{~s})$. Assuming equilibrium with this uranyl solid, they used the MINEQL geochemical model (Westall, Zachary, and Morel 1976) to calculate the concentrations of total dissolved uranium as a function of $\mathrm{pH}$. Relyea and Silva (1981) found that the model calculations were inaccurate above $\mathrm{pH} 7$ without the inclusion of the species $\mathrm{UO}_{2}(\mathrm{OH})_{2}^{\mathrm{O}}$ and $\left(\mathrm{UO}_{2}\right)_{3}(\mathrm{OH})_{7}$. Unfortunately, Relyea and Silva do not mention if a uranyl hydroxide or any other uranium solid (such as the sodium uranates--Wamser et al. 1952; Brush 1980) was identified as a precipitate in their sorption experiments.

Maya and Begun (1981) measured the Raman spectra of several U(VI) species in carbonate and alkaline solutions. Their measurements indicated the existence of one or possibly two anionic U(VI) species, such as $\mathrm{UO}_{2}(\mathrm{OH})_{4}^{2-}$, in noncarbonate alkaline solutions. Because of the low solubility of sodium uranates and their formation at $\mathrm{pH}$ values as low as 4 (Wamser et al. 1952), Maya and Begun used tetramethylammonium hydroxide to obtain alkaline solutions $(\mathrm{pH}>12)$ of approximately $0.01 \mathrm{M}$ total dissolved uranium. The Raman spectra for these solutions showed a band that could not be attributed to the pure reagents and whose relative intensity increased with the concentration of dissolved uranium. Maya and Begun (1981) used this information for solutions with $\mathrm{pH}$ values of 12.6 and 13.7 to demonstrate the existence of two separate anionic hydroxyl species for $U(V I)$ in alkaline solutions.

Sylva and Davidson (1979) investigated the hydrolysis of dissolved U(VI) over the $\mathrm{pH}$ range of 3 to 6 at $25^{\circ} \mathrm{C}$ using potentiometric titration in $0,1 \mathrm{M} \mathrm{KNO}_{3}$ solutions. They derived cumulative equilibrium constants for each complex in a speciation scheme that included $\mathrm{UO}_{2}(\mathrm{OH})^{+},\left(\mathrm{UO}_{2}\right)_{2}(\mathrm{OH})_{2}^{2+}$,

QMin-u-sil is a registered trademark of Pennsylvania Glass-Sand Corporation, Pittsburg, Pennsylvania. 
$\left(\mathrm{UO}_{2}\right)_{3}(\mathrm{OH})_{4}^{++},\left(\mathrm{UO}_{2}\right)_{3}(\mathrm{OH})_{5}^{+}$, and $\left(\mathrm{UO}_{2}\right)_{4}(\mathrm{OH})_{7}^{+}$. Of these five hydroxyl complexes, $\left(\mathrm{UO}_{2}\right)_{3}(\mathrm{OH})_{4}^{2+}$ and $\left.\left(\mathrm{UO}_{2}\right)_{4}(\mathrm{OH})\right\rangle_{7}^{\dagger}$ were not included in the tabulations of Langmuir (1978) and Lemire and Tremaine (1980).

The published literature, however, does not provide a rational basis for selecting among the proposed polynuclear hydroxyl complexes of U(VI). 
APPENDIX C

U(IV) HYDROXYL SPECIES 


\section{U(IV) HYDROXYL SPECIES}

Because of the major importance of the stability constants of U(IV) hydroxyl complexes to solubility calculations under reducing conditions, a set of $\log K_{r, 298}^{0}$ values that could be compared with those in Langmuir (1978) were estimated from the solubility data determined by Tremaine et al. (1981) for natural $\mathrm{UO}_{2}(\mathrm{c})$ under alkaline conditions. These new $\log \mathrm{K}_{r, 298}^{0}$ (and therefore $\Delta G \&, 298)$ values are for the $U($ IV $)$ species $U(O H)_{2}^{2+}, U(O H)_{3}^{+}, U(O H)_{4}^{0}$, and $U(\mathrm{OH})_{5} \cdot$ Comparison of the X-ray diffraction unit cell data in Tremaine et al. (1981) to the data tabulated in Robie, Bethke, and Beardsley (1967) indicates the $\mathrm{UO}_{2}(\mathrm{c})$ sample used by Tremaine et al. (1981) to be the mineral uraninite $\left(\mathrm{UO}_{2}\right)$. Tremaine et al. present the solubility expression ( $T$ in degrees Kelvin):

$$
\log K_{r, T}^{0}=-5.86+32 T^{-1}
$$

which was fit to their solubility data from $25^{\circ} \mathrm{C}$ to $200^{\circ} \mathrm{C}$ for the reaction,

$$
\mathrm{UO}_{2}(\mathrm{c})+2 \mathrm{H}_{2} \mathrm{O}+\mathrm{OH}^{-}=\mathrm{U}(\mathrm{OH})_{5}^{-} \cdot
$$

This reaction is consistent with the slope,

d $\log m$ (total dissolved $U) / d \log m(L i O H)=1.2 \pm 0.3$, of a plot of their solubility data for $\mathrm{UO}_{2}(\mathrm{c})$. By substituting $298 \mathrm{~K}\left(25.0^{\circ} \mathrm{C}\right)$ into the above expression for $\log K_{r, T}^{0}$, one can calculate $\log K_{r, 298}^{0}$, and thus $\Delta_{r, 298}^{0}$, for the above $U 0_{2}$-dissolution reaction. By combining this $\Delta G_{r, 298}^{0}$ with $\Delta G_{f, 298}^{0}$ values for uraninite from Langmuir (1978) and for $\mathrm{H}_{2} \mathrm{O}(1)$ and $\mathrm{OH}^{-}$as used for the WATEQ4 data base (Krupka and Jenne 1982), $\Delta G_{f, 298}^{0}$ was calculated for $\mathrm{U}(\mathrm{OH})_{5}$. This is essentially the same computational procedure used by Langmuir (1978) to derive $\Delta G_{f, 298}^{0}$ for $U(O H)_{5}^{-}$from the solubility data for $U(\mathrm{OH})_{4}(s)$ by Gayer and Leider (1957).

Major internal inconsistencies would result, however, if the new $\triangle G Q, 298$ for $U(\mathrm{OH})_{5}$, dertued from the data of Tremaine et al. (1981), were used with the 
data for $\mathrm{U}(\mathrm{OH})\}^{+}, \mathrm{U}(\mathrm{OH})_{3}^{+}$, and $\mathrm{U}(\mathrm{OH}) \&$ from Langmuir (1978), to calculate aqueous speciation and solubility controls for dissolved U(IV). As described in the notes to Table 1 in Langmuir (1978, p. 550), the thermodynamic data for the intermediate hydrolysis constants for U(IV) were estimated from Langmuir's "accepted" $\Delta G q, 298$ values for $U \mathrm{OH}^{3+}$ and $U(\mathrm{OH})_{5}$. Therefore, if the new $\Delta G_{f, 298}^{0}$ for $U(\mathrm{OH})_{5}$ based on the solubility data from Tremaine et al. (1981) is to be accepted, Langmuir's entire hydrolysis scheme for U(IV) must be recalculated.

New thermodynamic values were calculated for the species $U(\mathrm{OH})_{2}^{2+}, U(\mathrm{OH})_{3}^{+}$, and $U(\mathrm{OH}) \&$. with the same scheme employed by Langmuir (1978) for these U(IV) species and described in Langmuir (1979, p. 372). Our use of this estimation method in this uranifum validation study dues liut cunstitute a technical-defense of this procedure; rather, the method is used because it provides a means of comparing the data derived for these U(IV) species to those similarly estimated by Langmuir (1978). Langmuir (1978) references the estimation scheme back to Beck (1970). The procedure can be used to calculate step-wise stability constants $(a)\left(K_{n}\right)$ for a series of electrostatically bonded complexes where the constants $K_{n}$ for two or more complexes are known. For this estimation scheme, the step-wise stability constants for any two successive complexes are assumed to be related by the expression:

$$
k_{n} k_{n+1}=10^{2 \lambda}
$$

where $\lambda$ is constant for a metal/ligand system [P.0.. II(IV) and $\mathrm{OH}^{-}$." "If this relation holds, the series of logs of the step-wise stability constants can be treated as the arithmetic progression

$$
a, a+d, a+2 d, \ldots ., \ell,
$$

(a) In the notation used by Langmuir (1979), the step-wise stability constants should be contrasted to cumulative stability constants $\left(B_{n}\right)$, where $B_{n}=$ $K_{1} \times K_{2} \times K_{3} \times \ldots K_{n}$. 
where $a$ is the first term (or $\log k_{1}$ ) and $d$ is the common difference (or $-2 \lambda)$. The last term $(l)$ in this series can be computed from the expression (Burington 1961):

$$
\ell=a+(n-1) d,
$$

where the term $\ell$, therefore, would correspond to a $\log K_{n}$ in a series of stepwise stability constants. Substitution of the equivalent terms into equation (C.2) results in the equation:

$$
\log k_{n}=\log k_{1}-2 \lambda(n-1)
$$

From the available thermodynamic data for water and the hydrolysis constants for U(IV), cumulative stability constants can be calculated only for the reactions:

$$
\mathrm{U}^{4+}+\mathrm{H}_{2} \mathrm{O}=\mathrm{UOH}^{3+}+\mathrm{H}^{+},
$$

and

$$
\mathrm{U}^{4+}+5 \mathrm{H}_{2} \mathrm{O}=\mathrm{U}(\mathrm{OH})_{5}^{-}+5 \mathrm{H}^{+}
$$

To estimate the stability constants for the hydrolysis species intermediate to $\mathrm{UOH}^{3+}$ and $\mathrm{U}(\mathrm{OH})_{5}$, Equation ( $\mathrm{C} .3$ ) must be reformulated to use the cumulative stability constants $\beta_{1}$ and $\beta_{5}$ for Reactions (C.4) and (C.5), respectively, to solve for $K_{1}$ and $\lambda$ in Equation (C.3). Because

$$
\beta_{n}=k_{1} \times k_{2} \times k_{3} \times \ldots \times k_{n},
$$

then

$$
\log \beta_{n}=\log K_{1}+\log K_{2}+\ldots+\log K_{n} .
$$


Equation (C.3) can then be substituted for each step-wise stability constant in the right side of Equation (C.6). By summing the common terms, Equation (C.6) now reduces to

$$
\log \beta_{n}=n \log k_{1}-2 \lambda \sum_{x=1}^{n}(x-1)
$$

Therefore, if the cumulative stability constants $\left(\beta_{n}\right)$ are known for two or more complexes in the step-wise series, we may solve for the two unknowns, $K_{1}$ and $\lambda$, in Equation (C.7). The unknown stability constants for the other complexes in the same serfes can then be estimated using Equation (C.7) to obtain values for $R_{n}$, or, equivalently, using Equation (C.3) to solve for values of $K_{n}$.

As described previously, cumulative stability constants could be calculated for the species $\mathrm{UOH}^{3+}\left[\right.$ Reaction (C.4)] and $U(\mathrm{OH})_{5}-$ [Reaction (C.5)] using the $\Delta G_{f, 298}^{0}$ for $U^{4+}, U \mathrm{OH}^{3+}$, and $U \mathrm{O}_{2}(\mathrm{c})$ in Langmuir (1978); for $U\left(U \mathrm{H}_{5} \overline{5}_{5}\right.$ as computed from the new solubility data of Tremaine et al. (1981); and for $\mathrm{H}_{2} \mathrm{O}(1)$ and $\mathrm{OH}^{-}$as used in WATEQ4 (Krupka and Jenne 1982). Using these $B_{n}$ values for $\mathrm{UOH}^{3+}$ and $\mathrm{U}(\mathrm{OH})_{5}$, step-wise stability constants $\left(K_{n}\right)$ were calculated with Equation (C.3) for the nydrolysis species $\mathrm{U}(\mathrm{OH})_{2}^{2+}, \mathrm{U}(\mathrm{OH})_{3}^{+}$, and $\mathrm{U}(\mathrm{OH})_{4}^{0}$. These values, including those for $\mathrm{UOH}^{3+}$ and $\mathrm{U}(\mathrm{OH})_{5}$, are shown in Figure $\mathrm{C.1}$. For comparison, $\log K_{n}$ values calculated for these sarne $U(I V)$ species using the thermodynamic data tabulated in Langmuir (1978), Baes and Mesmer (1976), and Allard, Kipatsi, and Liljenzin (1980), are also plotted in Figure C.1. Lemire and Tremaine (1980) adopted the $\Delta G_{f}^{0}, 298$ and $S_{298}^{0}$ values tabulated for the mononuclear. hydrolysis species in Langmuir (1978). Using these new estimates for $\log K_{n}, \Delta G_{f}^{0}, 29 g$ values were then calculated for these three U(IV) species. Similarly, $\Delta H_{f}, 298$ values are necessry to derive $\Delta H_{r, 298}^{0}$ for the reactions of these species in WATEQ4 in order to use the van't Hoff relation for temperature extrapolations of $\log K_{r_{3}}^{U}$ up to $100^{\circ} \mathrm{C}$. Ine newly estimated thermodynamic data for the species $U(\mathrm{OH})_{2}^{\frac{3}{+}}, U(\mathrm{OH})_{3}^{+}, U(\mathrm{OH})_{4}^{0}$, and $U(\mathrm{OH})_{5}^{-}$will be 


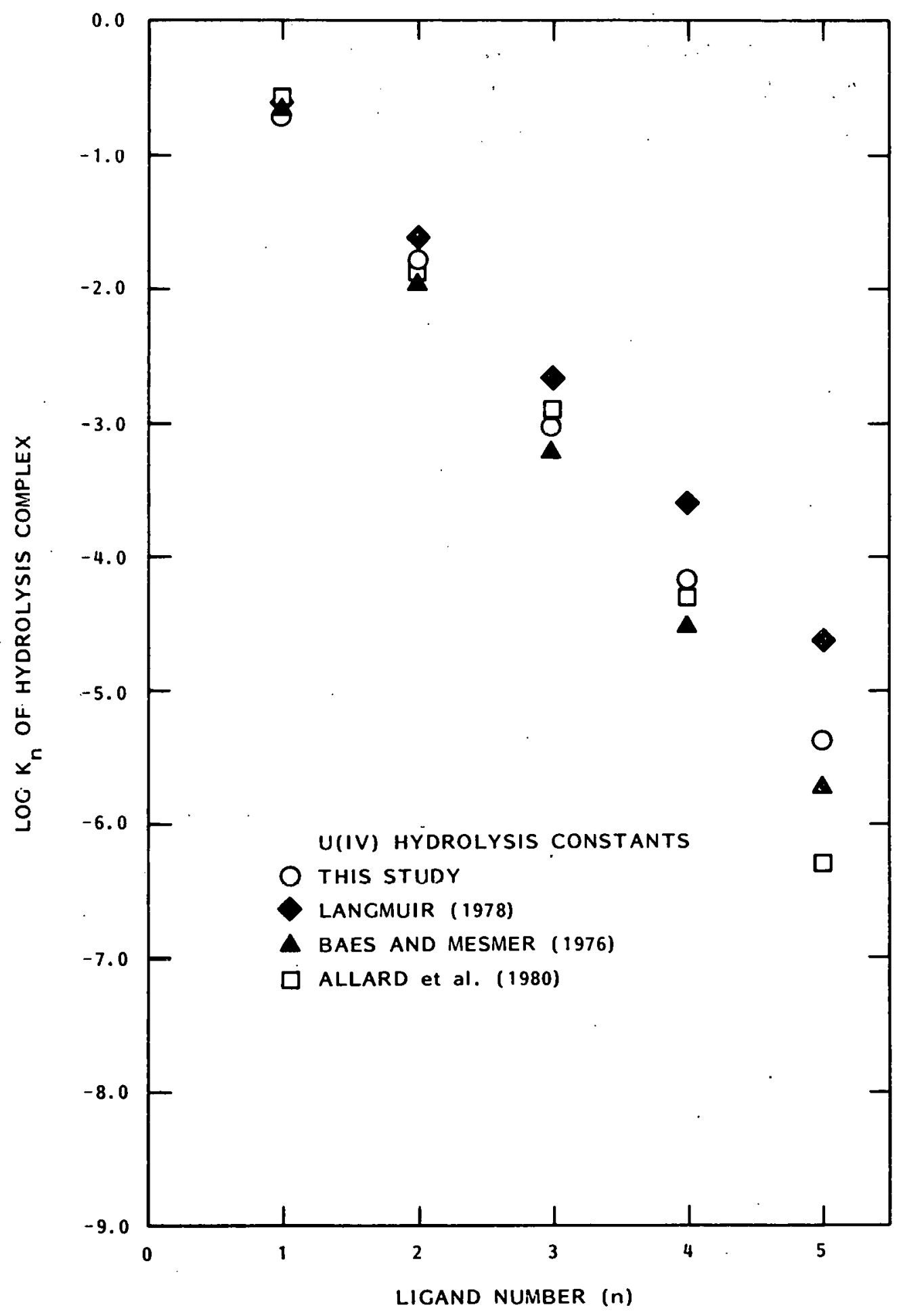

FIGURE C.1. Comparison of Step-Wise Stability Constants at $25^{\circ} \mathrm{C}$ for U(IV)Hydroxyl Complexes Estimated from the Data of Tremaine et al. (1981) Versus Tnose Given in Otner Tabulations of Thermodynamic Data 
used in comparison to those in Langmuir (1978), for sensitivity analyses in modeling the total concentrations of dissolved uranium expected from equilibrium with the mineral uraninite $\left[\mathrm{UO}_{2}(\mathrm{c})\right]$. 
APPENDIX D

URANYL $\mathrm{PO}_{4}$ AND $\mathrm{CO}_{3}$ COMPLEXES 
APPENDIX D

URANYL $\mathrm{PO}_{4} \mathrm{AND} \mathrm{CO}_{3}$ COMPLEXES

The $\log K_{r, 298}^{0}$ and $\Delta H_{r, 298}^{0}$ values in the WATEQ4 data base for the species $\mathrm{UO}_{2}\left(\mathrm{HPO}_{4}\right) 2^{2}$ - were revised using the new cumulative association constant calculated by Dongarra and Langmuir (1980) from potentiometric titrations in $\mathrm{Na}_{2} \mathrm{HPO}_{4}-\mathrm{UO}_{2}\left(\mathrm{NO}_{3}\right)_{2}$ solutions. These measurements covered the $\mathrm{pH}$ range of 4 to 5 at ionic strengths less than 0.024. Using these analytical data, Dongarra and Langmuir (1980) used the Newton-Raphson iteration method to calculate a cumulative association constant $\left(\log R_{298}=18.3 \pm 0.2\right)$ for the reaction:

$$
\mathrm{UO}_{2}^{2+}+2 \mathrm{HPO}_{4}^{2-}=\mathrm{UO}_{2}\left(\mathrm{HPO}_{4}\right)_{2}^{2-} \cdot
$$

This equilibrium constant and the $\Delta G_{f}^{0}, 298$ values for $U 0_{2}^{2+}$ (Langmuir 1978) and $\mathrm{HPO}_{4}$ - (from WATEQ3 data base) were used to calculate a revised value for $\triangle G_{f}^{0}, 298$ of $\mathrm{UO}_{2}\left(\mathrm{HPO}_{4}\right)_{2}^{2-}$. By combining this $\Delta G^{2}, 298$ with $S_{298}^{0}$ values for $\mathrm{UO}_{2}\left(\mathrm{HPO}_{4}\right)_{2}^{2-}$ (estimated by Langmuir 1978) and its constituent elements (Krupka and Jenne 1982, Table 2), $\Delta H Q, 298$ was derived for this uranyl phosphate complex. This then permits adjustment of $\log K_{r, T}^{0}$ to the temperature of the solution, via the van't Hoff relation.

Langmuir (1978) and (1979), however, noted that his selected value for the $\Delta G_{f, 298}^{0}$ of $\mathrm{UO}_{2}\left(\mathrm{HPO}_{4}\right)_{2}$ - appears to be in error when compared to the trends in equilibrium constants for monomeric complexes of $U(V I)$ and $U(I V)$. Langmuir (1978) calculated the $\Delta G_{f}^{0}, 298$ for $\mathrm{UO}_{2}\left(\mathrm{HPO}_{4}\right)_{2}^{2-}$ from the solubility data of Moskvin, Shelyakina, and Perminov (1967). When the equilibrium constants for $\mathrm{UO}_{2} \mathrm{HPO}_{4}^{\circ}$ and $\mathrm{UO}_{2}\left(\mathrm{HPO}_{4}\right)_{2}^{2-}$ are plotted versus their ligand numbers, the line joining these two data points (see figure 3 in Langmuir 1978) has a distinctly steeper slope than similar data plotted for the other monomeric complexes of $U(V I)$ and U(IV). Based on this evidence, Langmuir (1978) concluded that strong consideration should be given to the re-evaluation of the equilibrium constants for these two uranyl phosphate species. In accord with this, A. P. Schwab and A. R. Felmy (Pacific Northwest Laboratory) have concluded that early Russian 
workers derived the association constants for $\mathrm{Pu}(\mathrm{IV})$ and $\mathrm{Pu}(\mathrm{VI})$ phosphate complexes using an incorrect speciation scheme for the phosphate ligand. Because several of the Russian investigators involved with the plutonium studies also participated in the investigation of the phosphate complexation. of $U(V I)$ and $U(I V)$, these uranium phosphate data are also suspect. This supports Langmuir's (1978 and 1979) suggestion that the association constants for the phosphate complexes of uranium be re-evaluated.

The cumulative equilibrium constant determined for $\mathrm{UO}_{2}\left(\mathrm{HPO}_{4}\right)$ ? - from the new measurements of Dongarra and Langmuir (1980), however, is in good agreement with the value taken from Moskvin, Shelyakima, and Perminov (1967). On the other hand, the derivation of the equilibrium constant for $\mathrm{UU}_{2}\left(\mathrm{HPO}_{4}\right) \frac{2}{2}$ : by Dongarra and Langmuir (1978) depends on their accepted thermodynamic values for the other hydroxyl and phosphate complexes of U(VI). This includes data for the species $\mathrm{UO}_{2} \mathrm{HPO}_{4}^{\circ}$, which Dongarra and Langmuir (1980) accepted from the solubility data of Moskvin, Shelyakima, and Perminov (1967). In view of these potential inconsistencies in the thermodynamic data for uranium complexes, a review is needed of the original references and their experimental data on which the association constants for $\mathrm{UO}_{2} \mathrm{HPO}_{4}^{\circ}$ and $\mathrm{UO}_{2}\left(\mathrm{HPO}_{4}\right)_{2}^{2-}$ are based.

Langmuir (1978) showed the major importance of carbonate complexation of dissolved uranium in oxidizing aqueous environments at $\mathrm{pH} \geq 5$. Therefore, evidence for the existence of the complexes $\mathrm{UO}_{2}\left(\mathrm{CO}_{3}\right)_{2}\left(\mathrm{H}_{2} \mathrm{O}\right)_{\frac{2}{2}}^{\frac{2}{2}}$ used in speciation-solubility calculations by a number of authors in the last 25 years needed to be evaluated for possible inclusion of this complex in WATEQ4. Mann (1974a,b) references Hostetler and Garrels (1962) and Garrels and Christ (1965) as the sources of thermodynamic data for the hydroxyl and carbonate complexes of uranium, which include $\mathrm{UO}_{2}\left(\mathrm{CO}_{3}\right)_{2}\left(\mathrm{H}_{2} \mathrm{O}\right)_{2}$ - - Hostetler and Garrels (1962) and Garrels and Christ (1965), in turn, reference Bullwinkel (1954) as the source of the $\Delta G_{f}^{0}, 298$ for this hydrated carbonate species. Garrels and Christ (1965) give $\Delta G 9,298=-622.0 \mathrm{kCal} \mathrm{mol}^{-1}$ for $\left.\mathrm{UO}_{2}\left(\mathrm{CO}_{3}\right)_{2}\left(\mathrm{H}_{2} \mathrm{O}\right)_{2}\right)^{-}$. However, based on the available data in Bullwinkel (1954), the species $\mathrm{UO}_{2}\left(\mathrm{CO}_{3}\right)_{2}\left(\mathrm{H}_{2} \mathrm{O}\right)_{2}^{2-}$ is chemically equivalent to the species $\mathrm{UO}_{2}\left(\mathrm{CO}_{3}\right)_{2}^{2-}$, which is included in the compilations of Langmuir (1978) and Lemire and Tremaine (1980). If this assumption is correct, then $\Delta G_{r, 298}^{0}=0$ for the reaction 


$$
\mathrm{UO}_{2}\left(\mathrm{CO}_{3}\right)_{2}\left(\mathrm{H}_{2} \mathrm{O}\right)_{2}^{2-}=\mathrm{UO}_{2}\left(\mathrm{CO}_{3}\right)_{2}^{2-}+2 \mathrm{H}_{2} \mathrm{O}
$$

Therefore, by combining this $\Delta G_{r}^{0}, 298$ with the $\Delta G \&, 298$ values for $\mathrm{UO}_{2}\left(\mathrm{CO}_{3}\right)_{2}\left(\mathrm{H}_{2} \mathrm{O}\right)_{2}^{2-}$ - from Bullwinkel (1954) and for $\mathrm{H}_{2} \mathrm{O}(1)$ from CODATA (1976), we obtain $\Delta G_{\mathrm{f}, 298}^{O}=-508.6 \mathrm{kcal} \mathrm{mol}-1$ for $\mathrm{UO}_{2}\left(\mathrm{CO}_{3}\right)_{2} 2^{-}$. The magnitude of this latter value obviously depends on the ancillary thermochemical data used by Bullwinkel (1954) for his calculations. Nonetheless, this $\Delta G_{f}^{0}, 298$ agrees very well with the $\Delta G Q, 298\left(-503.2 \mathrm{kcal} \mathrm{mol}^{-1}\right)$ choosen for $\mathrm{UO}_{2}\left(\mathrm{CO}_{3}\right)_{2}^{2-}$ by Langmuir (1978) from the data of Tsymbal (1969). Thus, the inclusion of both $\mathrm{UO}_{2}\left(\mathrm{CO}_{3}\right)_{2}\left(\mathrm{H}_{2} \mathrm{O}\right)_{2}^{2-}$ and $\mathrm{UO}_{2}\left(\mathrm{CO}_{3}\right)_{2}^{2-}$ would result in a duplication of complexation reactions for uranium and incorrect speciation-solubility calculations for $U(V I)$ dissolved in alkaline, carbonate solutions. It seems reasonable, therefore, to suggest that the use of the species $\mathrm{UO}_{2}\left(\mathrm{CO}_{3}\right)_{2}\left(\mathrm{H}_{2} \mathrm{O}\right)_{2}^{2-}$ should be discontinued in favor of the $\mathrm{UO}_{2}\left(\mathrm{CO}_{3}\right)_{2}^{2-}$ complex tabulated by Langmuir (1979) and Lemire and Tremaine (1980). (a)

(a) Although nothing was stated above concerning hydrated carbonate complexes for U(VI), Maya and Begun (1981) did find evidence using Raman spectroscopy of the existence of an uranyl hydroxyl carbonate complex, $\left(\mathrm{UO}_{2}\right)_{2} \mathrm{CO}_{3}(\mathrm{OH})_{3}$. Details for the evidence of this species, although outlined in Maya and Begun (1981), are as yet unpublished. 


\section{APPENDIX E}

$$
\text { REVISED } \triangle H_{f, 298}^{\circ} \text { FOR }\left(\mathrm{UO}_{2}\right)_{3}\left(\mathrm{PO}_{4}\right)_{2}
$$


REVISED $\Delta H_{\mathrm{f}, 298}^{\mathrm{O}}$ FOR $\left(\mathrm{UO}_{2}\right)_{3}\left(\mathrm{PO}_{4}\right)_{2}$

Ball, Jenne, and Cantrell (1981) calculated $\log K_{r, 298}^{0}$ values for the dissolution of $\left(\mathrm{UO}_{2}\right)_{3}\left(\mathrm{PO}_{4}\right)_{2}$ of -129.134 and -49.037 , respectively, using Langmuir's $\Delta H_{f, 298}^{O} / S_{298}^{O}$ values (Equation 3) and $\Delta G$, 298 values (Equation 2 ). This enormous difference in the $\log K_{r, 298}^{0}$ values is apparently. due to Langmuir's incorrect estimation of $\Delta H_{f, 298}^{0}$ for $\left(\mathrm{UO}_{2}\right)_{3}\left(\mathrm{PO}_{4}\right)_{2}$. The $\Delta \mathrm{G}_{\mathrm{f}, 298}^{\mathrm{O}, 29}$ for. this phosphate solid in Langmuir (1978) is based on the solubility measurement of Chukhlantsev and Alyamovskaya (1961). The value of $S_{298}^{0}$, on the other hand, was estimated by Langmuir (1978, p. 551) using the method of Latimer (1952); $\Delta H_{f, 298}^{0}$ for $\left(\mathrm{UO}_{2}\right)_{3}\left(\mathrm{PO}_{4}\right)_{2}$ was then apparently calculated from these $\Delta G_{\mathrm{f}, 298}^{0}$ and $S_{298}^{0}$ values.

From basic thermodynamic principles (Lewis and Randall 1961), $\Delta G_{f ; 298}^{0}$ for a given chemical component, whether solid phase or aqueous species, can be calculated by the relation:

$$
\Delta G_{f, 298}^{0}=\Delta H_{f, 298}^{0}-298.15 \Delta S_{298}^{0},
$$

where $\Delta S_{298}^{0}$ is the difference in entropy for a given component and the entropies of its elemental constituents in their reference state at $298 \mathrm{~K}$ and 1 atmosphere. (a) If one assumes that the values for $\Delta G_{f, 298}^{O}$ and $\Delta H_{f, 298}^{0}$ of $\left(\mathrm{UO}_{2}\right)_{3}\left(\mathrm{PO}_{4}\right)_{2}$ are correct, these data may be combined with the necessary ancillary data for $s_{298}^{0}$ of the elements uranium $(U)$, oxygen $\left[0_{2}(g)\right]$, and

(a) By convention, $\Delta H Q$, 298. for elements in their reference state is zero. 
phosphorous ( $P, \alpha$, white) (a) to calculate $S 298=-269 \mathrm{cal} \mathrm{mol}^{-1} \mathrm{~K}^{-1}$ for $\left(\mathrm{UO}_{2}\right)_{3}\left(\mathrm{PO}_{4}\right)_{2}$. Because heat capacity $\left(\mathrm{C}_{\mathrm{P}}^{\circ}\right)$ values at $\mathrm{T}>-273^{\circ} \mathrm{C}(0 \mathrm{~K})$ are positive for solids and

$$
s_{T}^{0}-s_{0}^{0}=\int_{0}^{T} C_{\beta}^{0} / T d T
$$

the calculation of a negative value for $\mathrm{S}_{298}$ of $\left(\mathrm{UO}_{2}\right)_{3}\left(\mathrm{PO}_{4}\right)_{2}$ is therefore erroneous. Unless there nas been a typuyraphical error in the tabulation of uranium data in Langmuir (1978), it would appear that a major part of the discrepancy between the two log $\mathrm{K}_{r}^{0}, 298$ values calculated by $\mathrm{Ba} 11$, Jenne, and Cantrell (1981) for $\left(\mathrm{UO}_{2}\right)_{3}\left(\mathrm{PO}_{4}\right)_{2}$ can be attributed to Langmuir's estimation of its $\Delta H_{f, 298}^{0}$. This $\Delta H_{f, 298}^{0}$ is obviously internally inconsistent with the $\Delta G_{f, 298}^{0}$ (based on solubility data) and the estimated $S_{298}^{0}$ values for $\left(\mathrm{UO}_{2}\right)_{3}\left(\mathrm{PO}_{4}\right)_{2}$ in Langmuir (1978). Because $\Delta H_{\mathrm{f}}^{0}, 298$ data are needed to use the van't Hoff relation for temperature extrapolation of $\log K_{r, 298}^{0}$ values, an internally consistent $\Delta H_{f, 298}^{O}$ value was calculated by combining $\Delta G_{f, 298}^{0}$ and $S_{298}^{0}$ for $\left(\mathrm{UO}_{2}\right)_{3}\left(\mathrm{PO}_{4}\right)_{2}$ in Langmuir (1978) with the ancillary entropy data for $U$, $U_{2}$ (gas), and $P(\alpha$, white $)$.

(a) Although Langmuir (1978) does not tabulate $\$ 298$ for elemental phosphorous, it was assumed that nis calculations were based on the alpha-white form of P. This appears to be consistent with nis data for otner pnosphorous compounds arid aqueous species (e.g., $\left.\mathrm{PO}_{4}^{3-}\right)$. Wagman et al. (1968) give $S_{298}^{0}=9.82 \mathrm{cal} \mathrm{mol}^{-1} \mathrm{~K}^{-1}$ for $\mathrm{P}(\alpha$, white $)$. The reader should note that $P($ red $)\left(S_{298}^{0}=5.46 \mathrm{cal} \mathrm{mol}^{-1} \mathrm{~K}^{-1}\right)$ is sometimes used in tabulations of thermodynamic data (e.g., Robie, Hemingway, and Fisher 1978) as the reference state of elemental phosphorous. If one mistakenly selected thermodynamic data for two solids or aqueous species containing $P$ that wcre based on the two different reference states of $P$, there would be an inconsistency between their $\Delta G Q$ Q 298 values of $1300 \mathrm{cal} \mathrm{mol}^{-1}$ [i.e., $298.15 \times(9.82-5.46)]$ per $p$ atom in their formula. 
n.

APPENDIX F

SODIUM URANATES 
SODIUM URANATES

Values of $\log \mathrm{K}_{r, 298}^{0}$ and $\Delta \mathrm{H}_{r, 298}^{0}$ for the hydrolysis reactions of $\mathrm{Na}_{3} \mathrm{UO}_{4}$, $\mathrm{Na}_{2} \mathrm{UO}_{4}$, and $\mathrm{Na}_{2} \mathrm{U}_{2} \mathrm{O}_{7}$ were added to the WATEQ4 data base. With the one exception of $\mathrm{S}_{298}$ for $\mathrm{Na}_{2} \mathrm{U}_{2} \mathrm{O}_{7}$, NBS Technical Note 270-8 (Wagman et al. 1981) was the source of $\Delta H_{f}, 298$ and $S_{298}^{0}$ data for these three solids. These data are in close agreement with the thermodynamic constants given for sodium uranates in Cordfunke and 0'Hare (1978). However, Wagman et al. (1981) did not report an $S_{298}^{0}$ value for $\mathrm{Na}_{2} \mathrm{U}_{2} \mathrm{O}_{7}$. A calorimetrically derived $\mathrm{S}_{298}^{\mathrm{O}}$ for $\mathrm{Na}_{2} \mathrm{U}_{2} \mathrm{O}_{7}$ was taken from Cordfunke et al. (1982). Previous solubility calculations by Paquette and Lemire (1981) and Muto (1965) used $\mathrm{S}_{298}^{0}$ values for $\mathrm{Na}_{2} \mathrm{U}_{2} \mathrm{O}_{7}$ that were estimated from oxide-summations of $C_{p}^{0}$ and from the method of Latimer (1952), respectively.

Lindemer, Besmann, and Johnson (1981) have reviewed the thermodynamic and high-temperature (from $25^{\circ} \mathrm{C}$ to melting temperatures) phase relations for the non-aqueous, alkali-metal oxide systems. Their review contains tabulated values of $\Delta H_{f, 298}^{0}$ and $S_{298}^{0}$ for uranate compounds, including several sodium uranate solids. Lindemer, Besmann and Johnson (1981) have included estimated $\Delta H_{f, 298}^{O}$ and $S_{298}^{O}$ data for the solid $\mathrm{Na}_{6} \mathrm{U}_{7} \mathrm{O}_{24}$. Although Wagman et al. (1981) do not tabulate an $\mathrm{S}_{298}$ value for this compound, they do give a value for $\Delta \mathrm{H}_{\mathrm{f}, 298}^{0}$ of $\mathrm{Na}_{6} \mathrm{U}_{7} \mathrm{O}_{24}$. The $\Delta \mathrm{H}_{\mathrm{f}, 298}^{\mathrm{O}}$ value for $\mathrm{Na}_{6} \mathrm{U}_{7} \mathrm{O}_{24}$ in Wagman et al. (1981) is nearly identical to that given in Cordfunke and $0^{\prime H}$ Hare (1978) but is 482 kcal more negative than that in Lindemer, Besmann, and Johnson (1981). Until this immense discrepancy can be resolved, thermodynamic data for $\mathrm{Na}_{6} \mathrm{U}_{7} \mathrm{O}_{24}$ cannot be added to the WATEQ4 data base. 
REFERENCE LIST OF LABORATORY STUDIES NOT USED FOR URANIUM VALIDATION 
APPENDIX G

REFERENCE LIST OF LABORATORY STUDIES

NOT USED FOR URANIUM VALIDATION

The following list of published laboratory studies involving uranium consists of those investigations rejected for use in the partial validation of WATEQ4 for uranium. These references do not appear in the main reference list of this report, but are included in this appendix as they may be of value to other readers studying the chemistry of dissolved uranium. Moreover, this. reference list will save effort in future validation studies of geochemical models for uranium by listing the studies that cannot be used for such purposés.

The primary selection criteria for studies used in the urantum validation were: 1) a uranium-bearing solid had to have been physically identified as contributing to the chemistry of the experimental aqueous system; and 2) water analyses had to minimally include total dissolved uranium, $\mathrm{pH}$, and temperature, as well as $E^{\mathrm{H}}$ for field studies. Values of $\mathrm{E}^{\mathrm{H}}$ could be estimated for laboratory studies of $U(V I)$. Studies in which the temperature or ionic strength ( $I \geq 0.5$ ) of the uranium solutions exceeded the modeling capability of WATEQ4 were also excluded from the uranium validation study. Moreover, although the reference titles seemed appropriate for the uranium validation study, a few studies were rejected because they contained no experimental data.

\section{REFERENCES}

Anders, 0. U., J. F. Bartel, and S. J. Altschuler. 1978. "Determination of the Leachability of Solids." Anal. Chem. 50:564-569.

Blake, C. A., C. F. Coleman, K. B. Brown, D. G. Hill, R. S. Lowrie, and J. M. Schmitt. 1956. "Studies in the Carbonate-Uranium System." J.Amer. Chem. 78:5978-5983.

Borovec, Z. 1981. "The Adsorption of Uranyl Spectes by Fine Clay." Chem. Geol. 32:45-58.

Ciavatta, L., D. Ferri, I. Grenthe, and F. Salvatore. 1981. "The First Acidification Step of the tris(carbonato)dioxouranate(VI) Ion, $\mathrm{UO}_{2}\left(\mathrm{CO}_{3}\right)_{3}^{-4}$." Inorg. Chem. 20:463-467. 
Du Preez, J. G. H., D. C. Morris, C. P. J. Van Vuuren, and M. Oertell. 1980. "The Chemistry of Uranium. Part XXVI. Alkaline Dissolution of Gold and/or Uranium Dioxide Powders." Hydrometallurgy 6:147-158.

Du Preez, J. G. H., D. C. Morris, and C. P. J. Van Vuuren. 1980. "The Chemistry of Uranium. Part XXVII. Kinetics of the Dissolution of Uranium Dioxide Powder in a Solution Containing Sodium Carbonate, Sodium Bicarbonate and Potassium Cyanide." Hydrometallurgy 6:197-201.

Ferri, D., I. Grenthe, and F. Salvatore. 1981. "Dioxouranium(VI) Carbonate Complexes in Neutral and Alkaline Solutions." Acta Chem. Scand. A35:165-168.

Forward, F. A., and J. Halpern. 1953a. "Studies in the Carbonate Leaching of Uranium Ores. I.-Description of the Pressure Leach Process and its

Application to Pitchblende Ores." Can. Mining and Metall. Bull. October 1953, pp. 643-640.

Forward, F. A., and J. Halpern. 1953b. "Studies in the Carbonate Leaching of Uranium Ores. III.-Precipitation of Uranium from Carbonate Solutions by Reduction with Hydrogen." Can. Mining and Metal1. Bull. October 1953, pp. 645-648.

Fuchs, L. H., and H. R. Hoekstra. 1959. "The Preparation and Properties of Uranium (IV) Silicate." Amer. Mineral. 44:1057-1063.

Fullman, H. T. 1981. Solubility Effects in Waste-Glass/Demineralized-Water System. PNL-3614, Pacific Northwest Laboratories, Richland, Washington.

Giblin, A. M., B. D. Batts, and D. J. Swaine. 1981. "Laboratory Simulation Studies of Uranium Mobility in Natural Waters." Geochim. Cosmo. Acta 45:699-709.

Goodwin, B. W. 1980. Maximum Total Uranium Solubilty Under Conditions Expected in a Nuclear Waste Vault. Whiteshell Nuclear Res. Establ. TR-29.

Grisham, G. F., E. A. Bryant, and K.E. Williams, 1979. Urananite Leaching. Literature Survey. LA-7799-MS, Los Alamos National Laboratory, Los Alamos, New Mexico.

Gromov, V. 1981. "Dissolution of Uranium Oxides in the Gamma-Radiation Field." Radiat. Phys. Chem. 18:135-146.

Hespe, E. D. 1971. "Leach lesting of Immobilized Radloactive Waste Solids." Atom. Energy Rev. 9:195-207.

Katayama, Y. B., and D. J. Bradley. 1980. "Long-Term Leaching of Irradiated Spent Fuel." In Scientific Bas is for Nuclear Waste Management, Vol. 2, C. J. M. Northup, Jr. (Ed.), Plenum PubT. Corp., New York, pp. 323-334. 
Lauffenburger, I., and R. Wey. 1966. "Sur l'incorporation de cations uranyle dams des carbonates en voie de formation." Bull. Soc. Chimeques 5:1743-1749.

Lietzke, M. H., and R. W. Stoughton. 1960. "The Solubility of Silver Sulfate in Electrolyte Solutions. Part 7. Solubility in Uranyl Sulfate

Solutions." J. Phys. Chem. 64:816-820.

MacKay, T. L., and M. E. Wadsworth. 1958. "A Kinetic Study of the Dissolution of $\mathrm{U0}_{2}$ in Sulfuric Acid." Am. Inst. Mining Metall. Petrol. Engineers Trans. 212:294-300.

Mende1, J. E. 1973. A Review of Leaching Test Methods and the Leachability of Various Solid Media Containing Radioactive Wastes. BNWL-1765, Pacific Northwest Laboratory, Richland, Washington.

Muto, T., S. Hirono, and H. Kurato. 1968. Some Aspects of Fixation of Uranium from Natural Waters. NSJ-Tr 91, Japan Atomic Energy Research Institute, Tokai-mura, Naka-gun, Abaragi-ken, Japan.

Norris, A. E. 1981. Fission Product Release: July 1 - September 30, 1980. LA-8699-PR, Los Alamos National Laboratory, LoS Alamos, New Mexico.

Pan, Y-M., C-B. Ma, and N-N. Hsu. 1981. "The Conversion of $\mathrm{UO}_{2}$, Via Ammonium Uranyl Carbonate: Study of Precipitation, Chemical Variation and Powder Properties." J. Nucl. Materials 99:135-147.

Pearson, R. L., and M. E. Wadsworth. 1958. "A Kinetic Study of the Dissolution of $\mathrm{UO}_{2}$ in Carbonate Solution." Am. Inst. Mining Metall. Petrol. Engineers Trans. 212:294-300.

Peters, E., and J. Halpern. 1953. "Studies in the Carbonate Leaching of Uranium Ores. II.-Kinetics of the Dissolution of Pitchblende." Can. Mining and Metal1. Bull. October 1953, pp. 640-644.

Peters, R. D., and H. Diamond. 1981. Actinide Leaching from Waste Glass: Air-Equilibrated Versus Deaerated Conditions. PNL-3971, Pacific Northwest Laboratory, Richland, Washington.

Relyea, J. F., and R. J. Silva. 1981. Application of a Site-Binding Electrical Double-Layer Model to Nuclear Waste Disposal. PNL-3898, Pacific Northwest Laboratory, Richland, Washington.

Ricci, J. R., and F. J. Loprest. 1955. "Phase Relations in the System Sodium Oxide-Uranium Trioxide-Water at 50 and $75^{\circ} \mathrm{C} . "$ J. Amer. Chem. Soc. 77:21192129.

Shortmann, W. E., and M. A. DeSesa. 1958. "Sec. United Nations Inter. Conf. on Peaceful Uses of Atomic Energy, Geneva," Proc., 3:333-341. 
Tsunashima, A., G. W. Brindley, and M. Bastovanov. 1981. "Adsorption of Uranium from Solutions by Montmorillonite; Compositions and Properties of Uranyl Montmorillonites." Clays and Clay Minerals 29:10-16.

Vidavskii, L. M., N. I. Byakhova, and E. A. Ippolitova. 1965. "Enthalpy of the Reaction of $\gamma-\mathrm{UO}_{3}$ with Hydrofluoric Acid and Enthalpy of Formation of $\gamma-\mathrm{UO}_{3}$." Russ. J. Inorg. Chem. 10:953-954. 


\section{APPENDIX H}

REVIEWS OF PUBLISHED LABORATORY SOLUBILITY AND GROUND-WATER DATA 


\section{REVIEWS OF PUBLISHED LABORATORY SOLUBILITY AND GROUND-WATER DATA}

Solution analyses from published laboratory and field studies were modeled to partially validate WATEQ4 with respect to uranium. The published investigations and the solution analyses selected for use in the validation study are described in thịs appendix. Concentrations of constituents reported in Tables H.1 through H. 10 represent the total concentration of that element constituent dissolved in solution. Unless otherwise stated, tabulated $\mathrm{E}^{\mathrm{H}}$ values were estimated using Equations (7) and (8).

\section{LABORATORY STUDIES}

A literature search was conducted to identify laboratory studies that involved the precipitation and/or dissolution of uranium-bearing solids. Solution analyses selected from these studies were used for the initial stages of the validation study because laboratory investigations generally involve chemical systems that are composed of only a few components and are chemically well characterized.

Brush (1980)

Brush (1980) investigated the solubility of some phases in the system $\mathrm{UO}_{3}$ $\mathrm{Na}_{2} \mathrm{O}-\mathrm{H}_{2} \mathrm{O}$ as a function of $\mathrm{pH}$ in saline at $60^{\circ} \mathrm{C}$ and in $0,1,2$, and $4 \mathrm{~m} \mathrm{NaCl}$ solutions at $90^{\circ} \mathrm{C}$. (a) The solubility experiments ranged from 12 to 600 hours ( 0.5 to 25 days, respectively) and approached equilibrium from both undersaturation and supersaturation. The solutions were purged with high-purity nitrogen to exclude $\mathrm{CO}_{2}$ and, thus, preclude the formation of uranyl carbonate complexes. Reaction products were characterized by X-ray diffractometry. In saline solutions, the solid $\alpha-\mathrm{UO}_{2}(\mathrm{OH})_{2}$ was the common run product. Two sodium uranates with a $\mathrm{Na}_{2} 0: \mathrm{UO}_{3}$ ratio of $1: 6$, however, were the main reaction products

(a) Brush (1980) is the apparent source for solubility data given by Holland and Brush (1978) at a conference on high-level radioactive solid waste forms. 
in acidic and neutral saline solutions. In basic saline solutions, a third sodium polyuranate with $\mathrm{Na}_{2} 0: \mathrm{UO}_{3}=1: 3$ was identified as a reaction product.

Twelve solution analyses (Table H.1) from Brush (1980, Table 3-1) were used for the validation study. The modeled solutions included those determined in saline and $0 \mathrm{~m} \mathrm{NaCl}$ solution, where final reaction products were identified. Because final concentrations of dissolved sodium were not reported, the modeled solutions were selected from those in which Brush identified $\alpha-\mathrm{UO}_{2}(\mathrm{OH})_{2}$ as a run product. The concentrations of dissolved uranium were determined by fluorimetric colorimetry and delayed neutron counting. Concentrations of dissolved $\mathrm{Na}$ and $\mathrm{Cl}$ were estimated trom the initial $\mathrm{NaCl}$ concentration: Before analysis, each aliquot of reaction solution was passed through a 1-um flller assembly. This assembly was heated to the run temperature to inhibit changes in the concentrations of dissolved constituents that might occur from cooling of the solution. Values of $E^{H}$ were not reported.

\section{Chukhlantsev and Stepanov (1956)}

Chukhlantsev and Stepanov (1956) determined the solubilities of three uranyl phosphates from their dissolution in weak nitric and sulfuric acid solutions at 19 to $20^{\circ} \mathrm{C}$. Solids of the general composition $\mathrm{UO}_{2} \mathrm{MPO}_{4}$ (where $\mathrm{M}$ is ammonium, hydrogen, or potassium) were synthesized via precipitation from aqueous solutions prepared from pure reagents. Each phosphate solid was placed in a flask containing the acidic solutions and shaken for 12 to 16 hours. Although no data were presented, Chukhlantsev and Stepanov (1956) report that they had established that a minimal dissolution period of 8 hours was required to attain equilibrium saturation with respect to each solid. Based on a review of their procedural information, these investigators appear to have taken no precautions to exclude air or $\mathrm{CO}_{2}$ from their leach solutions.

The equilibrium $\mathrm{pH}$ and concentration of dissolved uranium were determined for the solutions at the end of the 12- to 16-hour dissulution period. The saturated solutions were separated from the suspended phosphate solids using ultrafine filters (size not specified). The $\mathrm{pH}$ values before and after the dissolution period were measured with a glass electrode. The total concentrations of dissolved uranium were determined using a photoelectric colorimeter. 
TABLE H.1. Solution Analyses Modeled from Brush (1980) and Saturation Indices for Selected Uranium Solids. [Sample numbers correspond to those in Brush (1980, Table 3-1).]

\begin{tabular}{|c|c|c|c|c|c|c|c|c|c|}
\hline \multirow{2}{*}{$\begin{array}{l}\text { Sample } \\
\text { Number }\end{array}$} & \multirow[b]{2}{*}{$\mathrm{pH}$} & \multirow[b]{2}{*}{$E^{H}$} & \multirow[b]{2}{*}{$T$} & \multirow[b]{2}{*}{$\mathrm{UO}_{2}^{2+}$} & \multirow[b]{2}{*}{$\mathrm{Na}^{+}$} & \multirow[b]{2}{*}{$\mathrm{Cl}^{-}$} & \multicolumn{3}{|c|}{ Saturation Indices } \\
\hline & & & & & & & $\mathrm{UO}_{2}(\mathrm{OH})_{2}$ & Schoepite & $\mathrm{UO}_{3}(\mathrm{c})$ \\
\hline & & (V) & $\left({ }^{\circ} \mathrm{C}\right)$ & $-\cdots--m$ & $g L^{-1}$ & -.. & & & v \\
\hline $15 \mathrm{E}$ & 5.26 & 0.49 & 90 & 0.69 & -- & -- & -0.363 & -0.444 & -1.8 \\
\hline 19 & 4.56 & 0.54 & 90 & 24.8 & - & -- & 0.221 & 0.140 & -1.2 \\
\hline 20 & 3.95 & 0.57 & 90 & 234.0 & 23.0 & 35.45 & 0.310 & 0.229 & -1.1 \\
\hline 27 & 5.07 & 0.51 & 90 & 3.42 & -- & -- & 0.037 & -0.044 & -1.4 \\
\hline 30 & 3.90 & 0.57 & 90 & 160.0 & 57.8 & 89.0 & 0.158 & 0.077 & -1.3 \\
\hline 38 & 3.71 & 0.59 & 90 & 292.0 & - & -- & 0.155 & 0.074 & -1.3 \\
\hline 43 & 3.23 & 0.61 & 90 & 1036.0 & -- & - & -0.095 & -0.176 & -1.5 \\
\hline 75 & 3.95 & 0.57 & 60 & 332.0 & -- & -- & -0.006 & 0.004 & -1.8 \\
\hline 80 & 4.29 & 0.55 & 60 & 168.0 & -- & -- & 0.133 & 0.143 & -1.6 \\
\hline 91 & 5.78 & 0.46 & 60 & 5.46 & 9.2 & 14.1 & 0.228 & 0.238 & -1.5 \\
\hline 31 & 5.01 & 0.51 & 90 & 14.0 & 57.8 & 89.0 & 0.335 & 0.253 & -1.1 \\
\hline 74 & 5.46 & 0.48 & 60 & 7.48 & 4.6 & 7.1 & 0.151 & 0.161 & -1.6 \\
\hline
\end{tabular}


The equilibrium concentrations of dissolved ammonia, potassium, and phosphate were calculated by Chukhlantsev and Stepanov (1956) using the analytically determined concentrations of dissolved uranium and assuming that each solid dissolved stoichiometrically with respect to the general formula $\mathrm{UO}_{2} \mathrm{MPO}_{4}$. Chukhlantsev and Stepanov (1956), however, did not report the initial acid concentrations or the final concentrations of dissolved sulfate and nitrate. To more adequately model the true compositions of these solutions, we assumed that sulfuric and nitric acids were completely disassociated in solution and estimated the initial concentrations of dissolved sulfate and nitrate from the $\mathrm{pH}$ values measured by Chukhlantsev and Stepanov (1956) before the dissolution experiments. The $\mathrm{pH}$ values (i.e., $\mathrm{H}^{+}$activities) of the final (or saturated) solution were not used to estimate the acid concentrations because of the : formation of hydrogen phosphate complexes. Values of $E^{H}$ were not reported.

Solution analyses used for the uranium validation were taken from Table III $\left(\mathrm{NH}_{4} \mathrm{UO}_{2} \mathrm{PO}_{4}\right)$, Table IV $\left(\mathrm{KUO}_{2} \mathrm{PO}_{4}\right)$, and Table VI $\left(\mathrm{HUO}_{2} \mathrm{PO}_{4}\right)$ in Chukhlantsev and Stepanov (1956). Because their solubility experiments covered a limited $\mathrm{pH}$ range (approximately $\mathrm{pH}=1.80$ to 2.85 ), the solution compositions (Tables $H .2 a$ and H.2b) selected for modeling were those at the extreme $\mathrm{pH}$ limits for each set of solutions. Chukhlantsev and Stepanov (1956) do not report if the dissolution of the uranyl phosphate solids resulted in the precipitation of any new solids. The assumption of stoichiometric dissolution for these phosphates would imply that no new solids were formed.

Gayer and Leider (1955)

Gayer and Leider (1955) investigated the solubility of $\mathrm{UO}_{3} \cdot \mathrm{H}_{2} \mathrm{O}$ [or $\left.\mathrm{UO}_{2}(\mathrm{OH})_{2}\right]^{(\mathrm{a})}$ in pure water, perchloric acid, and sodium hydroxide solutions at $25^{\circ} \mathrm{C}$. All aqueous solutions were prepared and stored under nitrogen in order to exclude dissolved $\mathrm{CO}_{2}$. Barium hydroxide solution was also added to the starting sodium hydroxide solutions to precipitate any remaining carbonate.

(a) Throughout the remainder of this report, the formula $\mathrm{UO}_{2}(\mathrm{OH})_{2}$ will be used for the monohydrated uranium trioxide. This formula corresponds to that used in Langmuir (1978) and Lemire and Tremaine (1980). However, the reader should note that our usage of $\mathrm{UO}_{2}(\mathrm{OH})_{2}$ will be equivalent to $\mathrm{UO}_{3} \cdot \mathrm{H}_{2} \mathrm{O}$. 
TABLE H.2a. Solution Analyses Modeled from Chukhlantsev and Stepanov (1956). [Sample numbers preceded by letters $A, K$, and $H$ are analyses taken, respectively, from Tables III, IV, and VI in Chukhiantser and Stepanov (1956).]

\begin{tabular}{|c|c|c|c|c|c|c|c|c|c|}
\hline $\begin{array}{l}\text { Sample } \\
\text { Number }\end{array}$ & $\mathrm{pH}$ & $E^{H}$ & $T$ & $\begin{array}{c}u 0_{2}^{2+} \\
\end{array}$ & $\mathrm{NH}_{4}^{+}$ & $\mathrm{PO}_{4}^{3-}$ & $\mathrm{NO}_{3}^{-}$ & $\mathrm{SO}_{4}^{2-}$ & $k^{+}$ \\
\hline & & (v) & $\left({ }^{\circ} \mathrm{C}\right)$ & - & & $(\mathrm{mol} \mathrm{kg}$ & $\left(\times 10^{4}\right)$ & $\cdots$ & \\
\hline$A 1$ & 1.85 & 0.70 & 19.5 & 3.49 & 3.49 & 3.49 & 158.5 & -- & -- \\
\hline A3 & 2.35 & 0.67 & 19.5 & 1.15 & 1.15 & 1.15 & 50.1 & -- & -- \\
\hline A4 & 1.90 & 0.69 & 19.5 & 3.74 & 3.74 & 3.74 & $-\infty$ & 158.5 & -- \\
\hline A6 & 2.35 & 0.67 & 19.5 & 1.26 & 1.26 & 1.26 & -- & 50.1 & -- \\
\hline K1 & 2.05 & 0.68 & 19.5 & 24.6 & -- & 24.6 & 158.5 & -- & 24.6 \\
\hline K3 & 2.85 & 0.64 & 19.5 & 5.75 & -- & 5.75 & 50.1 & -- & 5.75 \\
\hline K4 & 2.00 & 0.69 & 19.5 & 24.8 & -. & 24.8 & -- & 158.5 & 24.8 \\
\hline K6 & 2.80 & 0.64 & 19.5 & 8.5 & -- & 8.5 & - & 50.1 & 8.5 \\
\hline $\mathrm{H} 2$ & 2.10 & 0.68 & 19.5 & 10.6 & -- & 10.6 & 100.0 & -- & -- \\
\hline $\mathrm{H} 4$ & 2.05 & 0.68 & 19.5 & 11.8 & -- & 11.8 & 100.0 & - & -- \\
\hline
\end{tabular}


TABLE H.2b. Saturation Indices for Selected Uranium Solids for Solution Analyses Modeled from Chukhlantsev and Stepanov (1956). [Designation of sample numbers same as in Table H.2a.]

\begin{tabular}{|c|c|c|c|c|c|}
\hline \multirow{2}{*}{$\begin{array}{l}\text { Sample } \\
\text { Number }\end{array}$} & \multicolumn{5}{|c|}{ Saturation Indices } \\
\hline & $\left(\mathrm{UO}_{2}\right)_{3}\left(\mathrm{PO}_{4}\right)_{2}$ & H-Autunite & Uramphite & K-Autunite & Schoepite \\
\hline$A 1$ & -1.1007 & -3.4 & -2.1 & -- & -5.8 \\
\hline A3 & -1.26 & -4.1 & -3.4 & -- & -5.1 \\
\hline A4 & -1.81 & -3.8 & -3.1 & -- & -6.0 \\
\hline A6 & -1.77 & -4.4 & -3.6 & $\quad--$ & $=5.1$ \\
\hline ki & 1.77 & -1.63 & -- & -2.425 & -4.6 \\
\hline $\mathrm{k} 3$ & 1.81 & -2.66 & $=-$ & -3.065 & $=3.6$ \\
\hline$k 4$ & 0.797 & -2.09 & -- & -3.045 & -5.1 \\
\hline$k 6$ & 1.51 & -2.70 & -- & -2.916 & -3.8 \\
\hline & & & & . & \\
\hline $\mathrm{H} 2$ & 0.919 & -2.28 & -- & -- & -4.8 \\
\hline H4 & 0.939 & -2.20 & -- & - & -4.9 \\
\hline
\end{tabular}


Hydrated uranium trioxide was synthesized from prolonged boiling. of a uranyl acetate solution. The uranium content of the prepared solid was determined to be $78.2 \mathrm{wt} \%$ (average of three analyses), which is essentially identical to the ideal uranium content of 78.29 wt\% for $\mathrm{UO}_{2}(\mathrm{OH})_{2}$. Each solubility experiment consisted of a pair of suspensions of $\mathrm{UO}_{2}(\mathrm{OH})_{2}$ in perchloric or sodium hydroxide solutions of desired concentrations. One suspension from each pair was shaken in a flask for at least 7 days at $35^{\circ} \mathrm{C}$. At the end of the equilibration period, the suspension was permitted to settle for 3 to 5 days at a controlled temperature of $25^{\circ} \mathrm{C}$. This same procedure was repeated for the second suspension; with an initial equilibration period at $25^{\circ} \mathrm{C}$, instead of $35^{\circ} \mathrm{C}$. Gayer and Leider (1955) apparently used the two equilibration periods at $25^{\circ} \mathrm{C}$ and $35^{\circ} \mathrm{C}$ to approach equilibrium solubility from both undersaturation and oversaturation. Gayer and Leider (1955) do not differentiate between these two types of solubility measurements in their tabulated solution analyses.

The equilibrium $\mathrm{pH}$ and concentration of dissolved uranium were determined at the end of the sedimentation periods at $25^{\circ} \mathrm{C}$. A glass electrode was used to determine $\mathrm{pH}$ values. Analyses of dissolved uranium were completed using a spectrophotometric procedure. Gayer and Leider (1955) do not mention if the final solutions were filtered before the uranium analyses. Values for $E^{H}$ of these solutions were not reported.

Solution analyses used for the uranium validation were selected from Tables I, II, and III in Gayer and Leider (1955). To minimize the number of. modeling runs without simultaneously degrading the results, solution analyses (Table H.3) were chosen for the uranium validation where discrete steps appeared in the tabulated values for $\mathrm{pH}$, uranium concentrations, or initial concentrations of perchloric acid and sodium hydroxide solutions. Tables I and II in Gayer and Leider (1955) include, respectively, the initial concentrations of sodium hydroxide and perchloric acid solutions, and do not contain the final $\mathrm{pH}$ values for the solubility experiments. To model these solutions, 
TABLE H.3. Solution Analyses Modeled from Gayer and Leider (1955) and Saturation Indices for Selected Uranium Minerals. [Sample numbers $B 1$ to $B 8, A 2$, and $A 11$ to $A 35$ are analyses taken, respectively, from Tables I, II, and III in Gayer and Leider (1955).].

\begin{tabular}{|c|c|c|c|c|c|c|c|c|c|}
\hline \multirow[b]{2}{*}{$\begin{array}{l}\text { Sample } \\
\text { Number }\end{array}$} & \multirow[b]{2}{*}{$\mathrm{pH}$} & \multirow[b]{2}{*}{$E^{H}$} & \multirow[b]{2}{*}{$T$} & \multirow[b]{2}{*}{$\mathrm{UO}_{2}^{2+}$} & \multirow[b]{2}{*}{$\mathrm{Na}^{+}$} & \multirow[b]{2}{*}{$\mathrm{ClO}_{4}^{-}$} & \multicolumn{3}{|c|}{ Saturation Indices } \\
\hline & & & & & & & Schoepite & $\mathrm{UO}_{2}(\mathrm{OH})_{2}$ & $\mathrm{UO}_{3}(\mathrm{c})$ \\
\hline & & (V) & $\left({ }^{\circ} \mathrm{C}\right)$ & $\ldots$ (mol & $\mathrm{kg}^{-1} \mathrm{x}$ & $\left.10^{4}\right)$ & & & \\
\hline B1 & 7.0 & 0.39 & 25 & 0.395 & -- & -- & 0.496 & $0.356^{\prime \prime}$ & -1.8 \\
\hline$B 2$ & 11.6 & 0.12 & 25 & 0.475 & 45.0 & - & 2.05 & 1.91 & -0.265 \\
\hline BR & 12.7 & 0.06 & 25 & 0.630 & 453.0 & -- & 2.4 & $2.3^{\circ}$ & 0.124 \\
\hline $\mathrm{A} 2$ & 1.7 & 0.70 & 25 & 184.0 & -- & 202.0 & -4.1 & -4.2 & -6.4 \\
\hline A11 & 5.22 & 0.50 & 25 & 3.99 & $\therefore-$ & 0.0602 & 0.213 & 0.073 & -2.1 \\
\hline A.15 & 5.01 & $0: 51$ & 25 & 6.17 & -- & 0.0977 & 0.193 & 0.053 & -2.1 \\
\hline$A 21$ & 4.76 & 0.52 & 25 & 11.7 & -- & 0.174 & 0.178 & 0.038 & $-2: 1$ \\
\hline$A 25$ & 4.38 & 0.55 & 25 & 37.0 & $\therefore$ & 0.417 & $\therefore \quad 0.147$ & 0.006 & -2.2 \\
\hline A29 & 4.20 & 0.56 & 25 & 46.2 & - & 0.631 & 0.037 & -0.103 & -2.3 \\
\hline A35 & 4.05 & 0.57 & 25 & 76.7 & $\Rightarrow$ & 0.891 & -0. คกต & -0.149 & -2.3 \\
\hline
\end{tabular}


$\mathrm{pH}$ values and concentrations of dissolved sodium and perchlorate(a) were estimated from these initial acid and base concentrations. Gayer and Leider (1955) include values in their Table III for the activity of $\mathrm{H}^{+}$for perchloric acid solutions at $25^{\circ} \mathrm{C}$, but they do not indicate whether these $\mathrm{pH}$ values are for the initial or final solutions. Concentrations of dissolved perchlorate were calculated from these $\mathrm{H}^{+}$activities.

Gayer and Leider (1955, p. 1448) report a limited amount of characterization data for uranium solids analyzed at the end of their solubility measurements. For three samples of solids studied in acidic solutions, the uranium contents were determined to be $77.5,77.8$, and $78.1 \mathrm{wt} \%$. These uranium values are lower by less than 1 wt\% from those measured for their synthesized $\mathrm{UO}_{2}(\mathrm{OH})_{2}$. The solid phase studied in the basic solution contains some "associated" sodium; no additional data were given by Gayer and Leider (1955).

Gayer and Leider (1957)

Gayer and Leider (1957) determined the solubility of $\mathrm{U}(\mathrm{OH})_{4}$ in pure water, perchloric acid, and sodium hydroxide solutions at $25^{\circ} \mathrm{C}$. Experimental procedures used by Gayer and Leider (1957) for the preparation of their acid and base solutions, the actual solubility experiments, and the analys is of dissolved uranium were identical to those in Gayer and Leider (1955). Values of $\mathrm{pH}$ for the initial or final solutions were not reported. Also, no mention was made of filtration, before the uranium analyses, of the solutions resulting from the solubility experiments. To "eliminate" oxidation, Gayer and Leider (1957) prepared and maintained the aqueous solutions under a positive pressure of nitrogen gas. Apparently, no other precautions were made to maintain reducing conditions in the solutions; Gayer and Leider (1957) do not report $\mathrm{E}^{\mathrm{H}}$ values for their solutions.

The $\mathrm{U}(\mathrm{OH})_{4}$ solid used as starting material in the acid solubility measurements was prepared by precipitation of a uranium sulfate solution with sodium

(a) Because WATEQ4 does not contain the species $\mathrm{ClO}_{4}^{-}$, the concentration of dissolved perchlorate was included as the species $\mathrm{I}^{-}$, as a means of checking the charge balance for the aqueous solution. This procedure will not result in any errors in the final speciation, because of a lack of complexation between $\mathrm{ClO}_{4}^{-}$or $\mathrm{I}^{-}$and the other constituents in these solutions. 
nydroxide. Gayer and Leider (1957) describe this precipitate as being gelatinous and extremely sensitive to oxidation. For the solubility measurements in sodium hydroxide solutions, $\mathrm{U}(\mathrm{OH})_{4}$ was synthesized by direct reaction of sodium hydroxide with $U\left(\mathrm{SO}_{4}\right)_{2} \cdot 4 \mathrm{H}_{2} \mathrm{O}(\mathrm{c})$. According to Gayer and Leider (1957); this latter procedure resulted in a dense nydroxide solid that was more stable to oxidation and easier to handle than the "precipitated" $\mathrm{U}(\mathrm{OH})_{4}$. To "eliminate" oxidation, the prepared solids were stored under a nitrogen atmosphere. Gayer and Leider (1957) present no chemical or crystallographic characterization data for the $\mathrm{U}(\mathrm{OH})_{4}$ samples. There are no data supporting the nature of their starting or final uranium solids. Unfortunately, the solubility of the denser $\mathrm{U}(\mathrm{OH})_{4}$ prepared from $\mathrm{U}\left(\mathrm{SO}_{4}\right)_{2} \cdot 4 \mathrm{H}_{2} \mathrm{O}(\mathrm{c})$ was not determined in the perchloric acid solutions.

For the uranium validation, solution analyses were selected from Tables I and II in Gayer and Leider (1957). Values of pH and concentrations of dissolved perchlorate and sodium were calculated, respectively, from the initial concentrations of perchloric acid and sodium hydroxide solutions. The modeled solution analyses included those from solubility measurements completed in pure water and at the extreme concentrations of perchloric acid and sodium hydroxide solutions.

Miller (1958)

To evaluate the geochemical conditions for the formation of pitchblende (i.e., massive uraninite), Miller (1958) investigated the stability of several uranium complexes and solids as a function of $\mathrm{pH}$, temperature, and pressure. The stability measurements of the aqueous species were completed by potentiometric titration of uranyl solutions witn different anions. The titration and solubility measurements were completed in a closed system under a nitrogen atmosphere to minimize the formation of uranium carbonate complexes and the oxidation of $U(I V)$ to $U(V I)$. Experiments completed at $T>100^{\circ} \mathrm{C}$ and/or $P>1 \mathrm{~atm}$ could not be used for the uranium validation because they exceeded the temperature/pressure competency of WATEQ4. In some titration experiments, Miller (1958) observed the precipitation of uranium solids as their solubility limits were exceeded during the course of the titrations. Solution analyses for the uranium validation were selected where Miller (1958) had identified the 
formation of uranium solids. The precipitates usually included uranyl hydrates and/or sodium uranates. The durations of the titration experiments were not specified.

Miller (1958) used two analytical procedures for determining the concentration of dissolved uranium. The "Jones Reductor Method" [see Miller (1958, p. 523-524) for description] with a potassium permanganate titration was used for uranium concentrations at or greater than 10-3 M. Concentration of dissolved uranium between $10^{-4}$ and 10-6 $M$ were determined by colorimetric methods. Before chemical analysis, solutions were filtered through a fine glass frit (size not specified). Values of, $E^{\mathrm{H}}$ were not reported. $X$-ray diffraction techniques were used to identify solid precipitates.

Solution analyses, unfortunately, were not tabulated in Miller (1958). His solution data were presented in either graphical form and/or descriptions in the text. Solution analyses (Table H.4) used for the uranium validation were generally taken from data points (i.e., filled circles) plotted in figures in Miller (1958). We assumed that these points, and not the connecting solid lines, represent Miller's actual experimental measurements. These analyses generally include $\mathrm{pH}$ values and concentrations of dissolved uranium. Concentrations of other dissolved constituents (e.g., sodium or sulfate) had to be estimated from the initial solution concentration and/or final pH values.

In potentiometric titrations of uranyl [U(VI)] sulfate solutions with sodium hydroxide at $25^{\circ} \mathrm{C}$, Miller (1958, p. 530) observed the precipitation of $\mathrm{Na}_{2} \mathrm{U}_{2} \mathrm{O}_{7}$ and $\mathrm{UO}_{2}(\mathrm{OH})_{2}$ at $\mathrm{pH}$ values above 4.5. The titration curve is shown as a function of $\mathrm{pH}$ versus millimoles $\mathrm{NaOH}$ in Figure 5 in Miller (1958). From these data, three solution compositions of constant concentrations of dissolved uranium and sulfate were modeled. The uranium and sulfate concentrations were calculated from the initial solution composition. Solution $\mathrm{pH}$ values were selected at 4.5 [above which precipitation was noted by Miller (1958)], 5.0, and 6.0. The concentrations of the $\mathrm{NaOH}$ titrating medium were determined from Miller's titration curve at $\mathrm{pH}$ values of $4.5,5.0$, and 6.0 . The concentrations of total sodium (i.e., that dissolved and contained in solid precipitates) were calculated from these sodium hydroxide concentrations and were included as such in the modeled solution analyses. 
TABLE H.4. Solution Analyses Modeled from Miller (1958) and Saturation Indices for Selected Uranium Minerals. [Sample numbers followed by the letters $S$ and $H$ are analyses taken, respectively, from Figures 5 and 8 in Miller (1958).]

\begin{tabular}{|c|c|c|c|c|c|c|c|c|c|}
\hline \multirow{2}{*}{$\begin{array}{l}\text { Sample } \\
\text { Number }\end{array}$} & \multirow[b]{2}{*}{$\mathrm{pH}$} & \multirow[b]{2}{*}{$E^{H}$} & \multirow[b]{2}{*}{$T$} & \multirow[b]{2}{*}{$\mathrm{UO}_{2}^{2+}$} & \multirow[b]{2}{*}{$\mathrm{SO}_{4}^{2-}$} & \multirow[b]{2}{*}{$\mathrm{Na}^{+}$} & \multicolumn{3}{|c|}{ Saturation Indices } \\
\hline & & & & & & & Schoepite & $\mathrm{UO}_{2}(\mathrm{OH})_{2}$ & $\mathrm{UO}_{3}(\mathrm{c})$ \\
\hline & & (v) & $\left({ }^{\circ} \mathrm{C}\right)$ & $--(\mathrm{mol}$ & $\mathrm{kg}^{-1} x$ & $\left.10^{4}\right)--$ & & & \\
\hline $4 S$ & 4.5 & 0.54 & 25 & 14.96 & 34.84 & 54.0 & -0.021 & -0.160 & -2.3 \\
\hline $5 S$ & 5.0 & 0.51 & 25 & 14.96 & 34.84 & 60.0 & 0.304 & 0.164 & -2.0 \\
\hline $6 S$ & 6.0 & 0.45 & 25 & 14.96 & 34.84 & 75.0 & 0.675 & 0.535 & -1.6 \\
\hline $4 \mathrm{H}$ & 4.7. & 0.53 & 25 & 47.1 & -- & -- & 0.376 & 0.236 & -1.9 \\
\hline $5 \mathrm{H}$ & 5.8 & 0.46 & 25 & 0.168 & -- & -- & -0.063 & -0.203 & -2.4 \\
\hline $7 H$ & 7.70 & 0.38 & 25 & 0.42 & -. & .. & 0.740 & 0.600 & -1.6 \\
\hline
\end{tabular}


Miller (1958, p. 532-533) presents solubility data for $\mathrm{UO}_{2}(\mathrm{OH})_{2}$ as a function of $\mathrm{pH}$ at $25^{\circ} \mathrm{C}$. Uranium concentrations at $\mathrm{pH}$ values of $4.7,5.8$, and 7.7 [all data points in Miller (1958, Figure 8)] were modeled for the uranium validation. Although these data were described as being in the absence of "foreign ions," Miller (1958) does not describe how the different pH values were achieved. Moreover, Miller (1958) does not report if these solubility concentrations were determined from undersaturation or oversaturation.

Several solution analyses were also modeled from data for the potentiometric titration of uranous [U(IV)] sulfate solutions by sodium hydroxide at $25^{\circ} \mathrm{C}$ (Miller 1958, Figure 17). During these titration measurements, Miller (1978) observed the formation of a black precipitate at $\mathrm{pH}=2.2$, which he labeled as solid $\mathrm{UO}(\mathrm{OH})_{2}$. According. to Miller, the X-ray diffraction pattern for this material, which had been dried at $25^{\circ} \mathrm{C}$, was slightly diffused, but identical to $\mathrm{UO}_{2}$ : : Concentrations of dissolved uranium and sulfate were calculated from the initial solution composition. The concentration of total sodium was determined from the titration curve at each selected pH. Unfortunately, these titration data for U(IV) solutions were of limited usefulness for the validation effort because $E^{H}$ values and final uranium concentrations were not reported (Miller 1958). Moskvin, Shelyakina, and Perminov (1967)

Moskvin, Shelyakina, and Perminov (1967) investigated the solubility of $\mathrm{UO}_{2} \mathrm{HPO}_{4} \cdot 4 \mathrm{H}_{2} \mathrm{O}$ in distilled water and $0.5 \mathrm{M}$ sodium perchlorate solution at an unspecified temperature, and in nitric acid solutions at 25,50 , and $70^{\circ} \mathrm{C}$. For the purpose of modeling, we assumed that the solubility studies in distilled water and sodium perchlorate solution were completed at $25^{\circ} \mathrm{C}$. : The preparations of the starting solutions and the synthetic $\mathrm{UO}_{2} \mathrm{HPO}_{4} \cdot 4 \mathrm{H}_{2} \mathrm{O}$ are not described. The solubility experiments consisted of mechanically stirring a mixture of the uranyl phosphate solid and each leachate solution in a reaction vessel (not described) until equilibrium was achieved. Moskvin, Shelyakina and Perminov (1967) state that 3 to 4 days were required for equilibration, but they provide no documentation to support this observation. Based on the available data, it appears that no steps were taken to exclude oxygen or carbon dioxide from the 
reaction vessels. The procedures used for the analysis of solution $\mathrm{pH}$ and concentration of dissolved uranium are not reported.

Solution analyses used for the uranium validation (Table H.5) were selected from Table 1 (distilled water and sodium perchlorate solutions) and Table 2 (nitric acid) in Moskvin, Shelyakina, and Perminov (1967). Because $\mathrm{UO}_{2} \mathrm{HPO}_{4} \cdot 4 \mathrm{H}_{2} \mathrm{O}$ was assumed to dissolve stoichiometrically, concentrations of total dissolved phosphate were calculated from the final concentrations of dissolved uranium. The solubility measurements completed in $0.5 \mathrm{M}$ sodium perchlorate covered the $\mathrm{pH}$ range of 1.1 to 8.7. Moskvin, Shelyakina, and Perminov (1967), however, do not explain how variable pH conditions were obtained. Concentrations of dissolved sodium, perchlorate, and nitrate were estimated from the starting concentrations of sodium perchlorate and nitric acid solutions. To reduce the number of data sets to be modeled, solution analyses between $\mathrm{pH}$ values of 1.1 and 1.8 in Table 1 of Moskvin, Shelyakina, and Perminov (1967) were not selected for the uranium validation. Only those solubility studies in $0.1 \mathrm{M}$ nitric acid at 25,50 , and $70^{\circ} \mathrm{C}$ (Moskvin, Shelyakina, and Perminov 1967, Table 2) were selected for the uranium validation, because the other acid concentrations exceeded the WATEQ4 capabilities for ionic strength corrections. Unfortunately, solution $\mathrm{pH}$ values for the nitric acid solutions had to be calculated from the tabulated " $\mathrm{H}^{+}$concentrations." Moskvin, Shelyakina, and Perminov (1967) do not describe how these $\mathrm{H}^{+}$concentrations were determined.

Mut.n (1.965)

Muto (1965) determined the solubilities of ningyoite $\left[\mathrm{CaU}\left(\mathrm{PO}_{4}\right)_{2} \cdot 2 \mathrm{H}_{2} \mathrm{O}\right]$, autunite $\left[\mathrm{Ca}\left(\mathrm{UO}_{2}\right)_{2}\left(\mathrm{PO}_{4}\right)_{2} \cdot 1 \mathrm{H}_{2} \mathrm{O}\right]$ and hydrogen-autunite $\left[\mathrm{H}_{2}\left(\mathrm{UO}_{2}\right)_{2}\left(\mathrm{PO}_{4}\right)_{2} \cdot 1 \mathrm{OH}_{2} \mathrm{O}\right]$ in hydrochloric acid solutions between 25 and $100^{\circ} \mathrm{C}$. The sample of ningyoite was synthesized hydrothermally from uranous chloride and calcium phosphate solution, and stored under nitrogen. Muto (1965) used natural material for the solubility measurements involving autunite. Hydrogen-autunite was prepared by precipitation from a phosphoric acid and uranyl chloride solution. These starting materials were identified by $X$-ray diffraction, and their compositions determined analytically (methods not specified). The solubility measurements 
TABLE H.5a. Solution Analyses Modeled from Moskvin, Shelyakina, and Perminov (1967). [Sample numbers $A 1$ to $A 10$ and $A 11$ to $A 25$ are analyses taken, respectively, from Tables 1 and 2 in Moskvin, Shelyakina, and Perminov (1967).]

\begin{tabular}{|c|c|c|c|c|c|c|c|c|}
\hline $\begin{array}{l}\text { Sample } \\
\text { Number }\end{array}$ & $\mathrm{pH}$ & $E^{H}$ & $T$ & $\mathrm{UO}_{2}^{2+}$ & $\mathrm{PO}_{4}^{3-}$ & $\mathrm{Na}^{+}$ & $\mathrm{ClO}_{4}^{-}$ & $\mathrm{NO}_{3}^{-}$ \\
\hline & & (v) & $\left({ }^{\circ} \mathrm{C}\right)$ & $-\ldots$ & -- (mol & $\mathrm{kg}^{-1} \times$ & t) $\ldots$ & $\ldots$ \\
\hline $\mathrm{Al}$ & 4.0 & 0.57 & 25 & 0.59 & 0.59 & -- & -- & -- \\
\hline $\mathrm{A} 2$ & 8.7 & 0.29 & 25 & 3.23 & 3.23 & 5000.0 & 5000.0 & - \\
\hline A3 & 4.2 & 0.56 & 25 & 3.36 & 3.36 & 5000.0 & 5000.0 & $\ldots$ \\
\hline A4 & 2.0 & 0.69 & 25 & 3.36 & 3.36 & 5000.0 & 5000.0 & - \\
\hline A5 & 1.8 & 0.70 & 25 & 23.0 & 23.0 & 5000.0 & 5000.0 & -- \\
\hline A10 & 1.1 & 0.74 & 25 & 90.0 & 90.0 & .5000 .0 & 5000.0 & -- \\
\hline A11 & 1.08 & 0.74 & 25 & 85.2 & 85.2 & -- & -- & 1000.0 \\
\hline A18 & 1.13 & 0.74 & 50 & 130.0 & 130.0 & -- & $\ldots$ & 1000.0 \\
\hline A25 & 1.13 & 0.74 & 70 & 130.0 & 130.0 & -- & -- & 1000.0 \\
\hline
\end{tabular}


TABLE H.5b. Saturation Indices for Selected Uranium Solids for Solution Analyses Modeled from Moskvin, Shelyakina,. and Perminov. (1967). [Designation of sample numbers same as in Table H.5a.]

\begin{tabular}{|c|c|c|c|c|}
\hline \multirow{2}{*}{$\begin{array}{l}\text { Sample } \\
\text { Number }\end{array}$} & \multicolumn{4}{|c|}{ Saturation Indices } \\
\hline & $\left(\mathrm{UO}_{2}\right)_{3}\left(\mathrm{PO}_{4}\right)_{2}$ & H-Autunite & Schoepite & $\mathrm{UO}_{2}(\mathrm{OH})_{2}$ \\
\hline $\mathrm{Al}$ & 0.201 & -4.3 & -2.0 & -2.2 \\
\hline $\mathrm{A} 2$ & -2.4 & -10.2 & 1.2 & 1.1 \\
\hline A3 & 1.39 & -3.7 & -1.4 & -1.5 \\
\hline$A 4$ & -2.9 & -3.8 & -5.6 & -5.8 \\
\hline $\mathrm{A} 5$ & -0.835 & -2.08 & -5.3 & -5.4 \\
\hline A 10 & -0.648 & -1.04 & -6.1 & -6.3 \\
\hline A11 & -0.575 & -0.976 & -6.1 & -6.2 \\
\hline A18 & -8.2 & 0.711 & -4.8 & -4.7 \\
\hline$A 25$ & -4.8 & 0.195 & -5.2 & -5.2 \\
\hline
\end{tabular}


consisted of reacting portions of the uranium phosphate solids in sealed polyethylene bottles containing distilled water. The initial $\mathrm{pH}$ values for the solutions were adjusted using hydrochloric acid. The bottles were opened for solution analysis at the end of a specified equilibration period. Muto (1965) determined these equilibration times in separate experiments by measuring the dissolution of ningyoite and autunite in solutions at $25^{\circ} \mathrm{C}$ and $\mathrm{pH} \simeq 3$ at 1,3 , 9, 30, and 90 days. For ningyoite, dissolution equilibrium was complete in less than 3 days. For autunite, equilibrium was $90 \%$ to $100 \%$ complete at 3 and 9 days, respectively. Accordingly, Muto (1965) used immersion periods of 5 and 3 days for the solubility experiments at 25 and $100^{\circ} \mathrm{C}$, respectively.

At the completion of the solubility experiments, $\mathrm{pH}$ values were measured with glass electrodes for the aqueous solutions decanted from the polyethylene bottles. These solutions were then passed through double sheets of filter paper, (a) and analyzed for dissolved uranium either by spectrophotometry or fluorimetry. Because ningyoite, autunite, and hydrogen-autunite were assumed to dissolve stoichiometrically, Muto (1965) calculated the concentrations of dissolved calcium and phosphate from the determined concentrations of dissolved uranium. Values of $E^{H}$ were not reported for the initial or final solutions. However, 'in the solubility experiments for ningyoite, Muto (1965, p. 248) reports the addition of trace quantities (concentrations not specified) of stannous chloride or sodium sulphite as an "antioxidant."

Muto (1965, p. 259) also determined the solubility of autunite and hydrogen-autunite from conditions of oversaturation. Autunite and hydrogenautunite were precipitated from solutions consisting of stoichiometric concentrations of uranium, phosphoric acid, and calcium. Final solution compositions and $\mathrm{pH}$ values were determined after a precipitation period of 15 to 40 days. No additional details or data were provided concerning these precipitation experiments.

Solution analyses selected for modeling (Table H.6) in the uranium validation were taken from Table 2 in Muto (1965). These data included solution

(a) Muto (1965) describes the type of filter paper as being "No. 5c." Pore size and manufacturer were not reported. 
TABLE H.6a. Solution Analyses Modeled from Muto (1965). [Sample numbers correspond to order of solution analyses in Table 2 in Muto (1965)]

\begin{tabular}{|c|c|c|c|c|c|c|c|}
\hline $\begin{array}{l}\text { Sample } \\
\text { Number }\end{array}$ & . $\mathrm{pH}$ & $E^{H}$ & $T$ & $\mathrm{UO}_{2}^{2+}$ & $\mathrm{Ca}^{2+}$ & $\mathrm{PO}_{4}^{3-}$ & $\mathrm{Cl}^{-}$ \\
\hline & & (v) & $\left({ }^{\circ} \mathrm{C}\right)$ & - & $\left(\mathrm{mol} \mathrm{kg}^{-}\right.$ & $\left.\times 10^{4}\right)$ & $\because$ \\
\hline 7 & 3.02 & 0.63 & 25 & 0.724 & 0.362 & 0.724 & 10.0 \\
\hline 8 & 3.79 & 0.58 & 25 & 0.115 & 0.0574 & 0.115 & 1.7 \\
\hline 9 & 4.78 & 0.52 & 25 & 0.0661 & 0.0330 & 0.0661 & 0.17 \\
\hline 10 & 1.80 & 0.10. & $2 b$ & 3.02 & -- & 3.02 & 170.0 \\
\hline 11 & 2.34 & 0.67 & 25 & 1.38 & $=-$ & 1.38 & 50.0 \\
\hline 12 & 3.23 & 0.61 & 25 & 0.3715 & -- & 0.3715 & 10.0 \\
\hline
\end{tabular}

TABLE H.6b. Saturation Indices for Selected Uranium Solids for Solution Analyses Modeled from Muto (1965). [Designation of sample numbers same as in Table H.6a.]

\begin{tabular}{|c|c|c|c|c|c|}
\hline \multirow{2}{*}{$\begin{array}{l}\text { Sample } \\
\text { Number }\end{array}$} & \multicolumn{5}{|c|}{ Saturation Indices } \\
\hline & $\left(\mathrm{UO}_{2}\right)_{3}\left(\mathrm{PO}_{4}\right)_{3}$ & H-Autunite & Autunite & Schoepite & $\mathrm{UO}_{2}(\mathrm{OH})_{2}$ \\
\hline 7 & -1.5 & -4.2 & -6.6 & $-3,9$ & -4.0 \\
\hline 8 & -2.3 & -5.7 & -7.4 & -3.1 & -3.2 \\
\hline 9 & -1.3 & -6.3 & -6.2 & -1.5 & -1.7 \\
\hline 10 & -2.6 & -3.4 & -- & -5.7 & -5.9 \\
\hline 11 & -2.2 & -3.8 & -- & -4.9 & -5.1 \\
\hline 12 & -1.9 & -4.7 & -- & -3.7 & -3.9 \\
\hline
\end{tabular}


compositions resulting from the dissolution of ningyoite at 25 and $100^{\circ} \mathrm{C}$, and of autunite and hydrogen-autunite at $25^{\circ} \mathrm{C}$. Solubility measurements at other temperatures were discussed by Muto (1965), but these experimental data were not presented. The range of $\mathrm{pH}$ values for solutions resulting from the solubility of ningyoite, autunite, and hydrogen-autunite were, respectively, 0.92 to $1.57,3.02$ to 4.78 , and 1.80 to 3.23 . The solubility of autunite could not be determined at $\mathrm{pH}$ values lower than approximately 3 , because the autunite would react to form hydrogen-autunite (i.e., $\mathrm{H}^{+}$replacement of $\mathrm{Ca}^{2+}$ ) at the lower $\mathrm{pH}$ values.

Robins (1966)

The precipitation of several uranyl [U(VI)] hydrates was studied by Robins (1966) as a function of $\mathrm{pH}$ and temperatures between 25 and $330^{\circ} \mathrm{C}$. Starting solutions consisted of $0.05 \mathrm{~m}$ uranyl nitrate solutions at $\mathrm{pH}$ values varied by unspecified additions of sodium hydroxide solution. These initial solutions were encapsulated in glass tubes, and heated electrically at a constant rate in a brass biock. As the anticipated temperatures for precipitation were approached, Robins (1966) maintained a heating rate of approximately $1^{\circ} \mathrm{C}$ min-1. $^{-1}$. When precipitation was observed in a given capsule, that capsule was removed from the block and the block's temperature was recorded at that instant. The precipitates in the resulting solutions were identified by $X$-ray powder diffraction analysis. The precipitates consisted of the U(VI) hydrates $\mathrm{UO}_{3} \cdot 2 \mathrm{H}_{2} \mathrm{O}$ (schoepite), $\mathrm{UO}_{3} \cdot 1 \mathrm{H}_{2} \mathrm{O}$ [or $\mathrm{UO}_{2}(\mathrm{OH})_{2}$ ], $\mathrm{UO}_{3} \cdot 0.8 \mathrm{H}_{2} \mathrm{O}$, and $\mathrm{UO}_{3} \cdot 0.5 \mathrm{H}_{2} \mathrm{O}$, with each hydrate stable, respectively, over a distinct temperature interval in the range from 25 to $330^{\circ} \mathrm{C}$.

Concentrations of dissolved uranium and $E^{H}$ and $\mathrm{pH}$ values for the final solutions were not reported. The initial pH values at $25^{\circ} \mathrm{C}$ were given, but the method of their determination was not described by Robins (1966). Solutions modeled in the uranium validation study (Table H.7) consisted of four pairs of $\mathrm{pH}$-temperature values between 25 and $100^{\circ} \mathrm{C}$ for a constant, initial solution of $0.05 \mathrm{~m}$ uranyl nitrate. These pH-temperature values, taken from Robins (1966, Figure 4), were determined to be the conditions necessary in a $0.05 \mathrm{~m}$ uranyl nitrate solution for precipitation of $\mathrm{UO}_{3} \cdot 2 \mathrm{H}_{2} \mathrm{O}$ between 25 and $60^{\circ} \mathrm{C}$ and of $\mathrm{UO}_{2}(\mathrm{OH})_{2}$ between 60 and $100^{\circ} \mathrm{C}$. A concentration of dissolved uranium of $0.05 \mathrm{~m}$ 
TABLE H.7. Solution Analyses Modeled from Robins (1966) and Saturation Indices for Selected Uranium Solids. [Sample numbers correspond to temperatures for experimental points in Figure 4 of Robins (1966).].

\begin{tabular}{|c|c|c|c|c|c|c|c|c|}
\hline \multirow[b]{2}{*}{$\begin{array}{l}\text { Sample } \\
\text { Number }\end{array}$} & \multirow[b]{2}{*}{$\mathrm{pH}$} & \multirow[b]{2}{*}{$E^{H}$} & \multirow[b]{2}{*}{$\mathrm{T}$} & \multirow[b]{2}{*}{$\mathrm{vO}_{2}^{2+}$} & \multirow[b]{2}{*}{$\mathrm{NO}_{3}^{-}$} & \multicolumn{3}{|c|}{ Saturation Indices } \\
\hline & & & & & & Schoepite & $\mathrm{UO}_{2}{ }^{(\mathrm{OH})_{2}}$ & $\mathrm{UO}_{3}(\mathrm{c})$ \\
\hline & & (v) & $\left({ }^{\circ} \mathrm{C}\right)$ & --- & $\mathrm{pm} \ldots$ & & & \\
\hline 25 & 3.75 & 0.58 & 25 & 11900.0 & 6200.0 & -0.040 & -0.179 & -2.4 \\
\hline 50 & 3.70 & 0.59 & 50 & 11900.0 & 6200.0 & 0.324 & 0.281 & -1.6 \\
\hline 65 & 3.60 & 0.59 & 65 & 11900.0 & 6200.0 & 0.425 & 0.432 & -1.3 \\
\hline 100 & 3.50 & 0.60 & 100 & 11900.0 & 6200.0 & 0.700 & 0.809 & -0.542 \\
\hline
\end{tabular}


was used for modeling these analyses. This concentration represents the amount of uranium in both the solution and precipitate, and does not indicate the final equilibrium concentration of dissolved uranium.

Sergeyeva et a1. (1972)

Sergeyeva et al. (1972) investigated the solubility of $\mathrm{UO}_{2} \mathrm{CO}_{3}$ (the mineral rutherfordine) between 25 and $200^{\circ} \mathrm{C}$, and the equilibrium between $\mathrm{UO}_{2} \mathrm{CO}_{3}$ and $\mathrm{UO}_{2}(\mathrm{OH})_{2}$ at 100,150 , and $200^{\circ} \mathrm{C}$. Because of the absence of solution analyses for experiments at $100^{\circ} \mathrm{C}$ and higher temperatures, only the solubility measurements at 25 and $50^{\circ} \mathrm{C}$, which were used in the uranium validation, will be described here. The $\mathrm{UO}_{2} \mathrm{CO}_{3}$ was synthesized by passing carbon dioxide gas through an aqueous suspension of uranyl hydroxide at ambient temperature. $X$-ray diffraction analysis was used to characterize the $\mathrm{UO}_{2} \mathrm{CO}_{3}$.

The procedure used for the solubility measurements was referenced to Nikitin et al. (1972), (a) and was only briefly described in Sergeyeva et al. (1972). The $\mathrm{UO}_{2} \mathrm{CO}_{3}$ solid was dissolved in glass vessels containing aqueous solutions of distilled water, sodium bicarbonate or perchloric acid-solutions. Moistened carbon dioxide gas at 1-atm pressure and the temperature of the experiment was bubbled through the reacting solutions. Sergeyeva et al. (1972) terminated the dissolution experiments when equilibrium was attained, as indicated by constancy in the solution $\mathrm{pH}$ values and concentration of dissolved uranium. The duration of the experiments was between 17 and 79 days at $25^{\circ} \mathrm{C}$ and between 9 and 31 days at $50^{\circ} \mathrm{C}$. Values of $\mathrm{pH}$ were measured with a glass electrode, and ranged between 3.22 and 6.23. Concentrations of dissolved uranium and sodium were determined, respectively, with colorimetry and flame photometry. Although Sergeyeva et al. (1972) do not explicitly indicate that the final solutions were filtered before their analysis, they briefly mention an "internal filter (partition)" located inside the glass solubility vessels. The purpose of these filters was not described, but it may have been to isolate the dispersion of $\mathrm{UO}_{2} \mathrm{CO}_{3}$ in the equilibrating solution. Values of $\mathrm{E}^{\mathrm{H}}$ were not reported.

(a) Reference not available to present authors. 
TABLE H.8. Solution Analyses Modeled from Sergeyeva et al. (1972) and Saturation Indices for Selected Uranium Solids. [Sample numbers preceded by the letters $A$ through $E$ correspond to solubility measurements completed, respectively, in hydrochloric acid, perchloric acid, and sodium bicarbonate solutions at $25^{\circ} \mathrm{C}$ and. perchloric acid and sodium bicarbonate solutions at $50^{\circ} \mathrm{C}$. See Table 1 in Sergeyeva et al. (1972).]

\begin{tabular}{|c|c|c|c|c|c|c|c|c|c|c|}
\hline \multirow[b]{2}{*}{$\begin{array}{l}\text { Sample } \\
\text { Number }\end{array}$} & \multirow[b]{2}{*}{$\mathrm{pH}$} & \multirow[b]{2}{*}{$E^{H}$} & \multirow[b]{2}{*}{$T$} & \multirow[b]{2}{*}{$v 0_{2}^{2+}$} & \multirow[b]{2}{*}{$\mathrm{Cl}^{-}$} & \multirow[b]{2}{*}{$\mathrm{CO}_{3}^{2-}$} & \multirow[b]{2}{*}{$\mathrm{ClO}_{4}^{-}$} & \multirow[b]{2}{*}{$\mathrm{Na}^{+}$} & \multicolumn{2}{|c|}{ Saturation Indices } \\
\hline & & & & & & & & & $\begin{array}{l}\text { Ruther- } \\
\text { fordine }\end{array}$ & Schoepite \\
\hline & & (V) & $\left({ }^{\circ} \mathrm{C}\right)$ & $\cdots$ & (mol & $\mathrm{kg}^{-1}$ & $10^{4}$ ) & -- & & \\
\hline $\begin{array}{l}\text { A1 } \\
\text { A2 } \\
\text { A3 }\end{array}$ & $\begin{array}{l}3.22 \\
4.09 \\
4.33\end{array}$ & $\begin{array}{l}0.61 \\
0.56 \\
0.55\end{array}$ & $\begin{array}{l}25 \\
25 \\
25\end{array}$ & $\begin{array}{c}25.3 \\
1.71 \\
0.63\end{array}$ & $\begin{array}{l}6.0 \\
0.81 \\
0.47\end{array}$ & $\begin{array}{l}35.3 .0 \\
355.0 \\
357.0\end{array}$ & $\begin{array}{l}-- \\
-- \\
=-\end{array}$ & $\begin{array}{l}-- \\
--\end{array}$ & $\begin{array}{r}-0.011 \\
0.311 \\
0.045\end{array}$ & $\begin{array}{l}-1.7 ? \\
-1.40 \\
-1.7\end{array}$ \\
\hline $\begin{array}{l}\text { B4 } \\
\text { B6 } \\
\text { B9 }\end{array}$ & $\begin{array}{l}4.44 \\
4.87 \\
5.31\end{array}$ & $\begin{array}{l}0.54 \\
0.52 \\
0.49\end{array}$ & $\begin{array}{l}25 \\
25 \\
25\end{array}$ & $\begin{array}{l}0.431 \\
0.571 \\
0.517\end{array}$ & $\begin{array}{l}-- \\
-- \\
--\end{array}$ & $\begin{array}{l}358.0 \\
365.0 \\
386.0\end{array}$ & $\begin{array}{l}0.36 \\
0.13 \\
0.049\end{array}$ & $\begin{array}{l}-- \\
--\end{array}$ & $\begin{array}{r}-0.079 \\
0.093 \\
-0.041\end{array}$ & $\begin{array}{l}-1.8 \\
-1.6 \\
-1.8\end{array}$ \\
\hline $\begin{array}{l}\text { C1 } \\
\text { C2 } \\
\text { C3 }\end{array}$ & $\begin{array}{l}5.55 \\
5.83 \\
6.23\end{array}$ & $\begin{array}{l}0.48 \\
0.46 \\
0.44\end{array}$ & $\begin{array}{l}25 \\
25 \\
25\end{array}$ & $\begin{array}{c}0.99 \\
1.45 \\
10.0\end{array}$ & $\begin{array}{l}-- \\
--\end{array}$ & $\begin{array}{l}409.0 \\
460.0 \\
622.0\end{array}$ & $\begin{array}{l}-- \\
--\end{array}$ & $\begin{array}{r}50.0 \\
100.0 \\
200.0\end{array}$ & $\begin{array}{r}0.042 \\
-0.209 \\
-0.249\end{array}$ & $\begin{array}{l}-1.7 \\
-1.9 \\
-1.9\end{array}$ \\
\hline $\begin{array}{l}D 1 \\
\text { D3 } \\
D 5\end{array}$ & $\begin{array}{l}3.47 \\
5.04 \\
5.28\end{array}$ & $\begin{array}{l}0.60 \\
0.31 \\
0.49\end{array}$ & $\begin{array}{l}50 \\
b 0 \\
50\end{array}$ & $\begin{array}{c}12.0 \\
U .45 \\
0.532\end{array}$ & $\begin{array}{l}-- \\
--\end{array}$ & $\begin{array}{l}185.0 \\
195.0 \\
202.0\end{array}$ & $\begin{array}{l}3.4 \\
U .0 y_{1} \\
0.052\end{array}$ & $\begin{array}{l}-- \\
-- \\
--\end{array}$ & $\begin{array}{r}0.059 \\
-0.002 \\
0.016\end{array}$ & $\begin{array}{l}-0.895 \\
-0.962 \\
-0.946\end{array}$ \\
\hline $\begin{array}{l}\mathrm{t} 1 \\
\mathrm{E} 2\end{array}$ & $\begin{array}{l}6.022 \\
6.16\end{array}$ & $\begin{array}{l}0.44 \\
0.44\end{array}$ & $\begin{array}{l}\text { bU } \\
50\end{array}$ & $\begin{array}{l}1.3 \\
7.0\end{array}$ & $=$ & $\begin{array}{l}28.3 .0 \\
321.0\end{array}$ & $=$ & $\begin{array}{l}100.0 \\
200.0\end{array}$ & $\begin{array}{l}-0.5 / 4 \\
-0.150\end{array}$ & $\begin{array}{l}-1.6 \\
-1.1\end{array}$ \\
\hline
\end{tabular}


Solution analyses selected from Sergeyeva et al. (1972, Table 1) for the uranium validation study are listed in Table H.8. The concentrations of total carbonate dissolved in the sodium bicarbonate and perchloric acid solutions were estimated from the $\mathrm{pH}$ values for the final solutions and the assumption of equilibrium with 1-atm carbon dioxide gas. The original concentrations for the sodium bicarbonate solutions were used to calculate the concentrations of total sodium (e.g., in solution plus that precipitated). To obtain a range of pH values, Sergeyeva et al. (1972) diluted the perchloric acid solutions with unspecified concentrations of distilled water. Because the initial pH values for the solvent were not tabulated, the concentrations of total dissolved perchlorate were estimated from the final $\mathrm{pH}$ values. Although the resulting perchlorate concentrations will be in error, they will not affect the calculated speciation because perchlorate does not complex with uranium, carbonate, and sodium. Approximately two-thirds of the perchlorate solutions were used for the uranium validation study. The remaining solutions were not modeled because their final $\mathrm{pH}$ values and uranium concentrations were similar to those modeled.

Wamser et al. (1952)

Wamser et al. (1952) studied the precipitation of sodium uranates (general formula $\mathrm{Na}_{X} \cup_{Y}^{6+} \mathrm{O}_{Z}$ ) at $25^{\circ} \mathrm{C}$ from mixtures of uranyl nitrate and carbon-free. sodium hydroxide solutions. Two initial solutions of 0.08 and $0.51 \mathrm{M}$ uranium nitrate with $\mathrm{pH}$ values of 2.68 and 1.94 , respectively, were used for the experiments. The sodium-uranium solids were formed by the addition of sodium hydroxide to these two nitrate solutions. Each mixture was placed in a sealed container and allowed to equilibrate with occasional stirring for five days. At the end of this period, the precipitates were washed by dispersion in water and then separated by centrifugation. Concentrations of sodium and uranium were determined, respectively, with gravimetric and spectrophotometric techniques. Whether Wamser et al. (1952) used these same methods for analysis of the compositions of both the solutions and the separated solids is uncertain. $X$-ray diffraction analysis was also used for the characterization of the precipitates. 
Two different precipitates were identified in these experiments. With the addition of sodium hydroxide, a stable precipitate was first formed at $\mathrm{pH}$ values of 4.4 and 3.6, respectively, in the 0.08 and $0.51 \mathrm{M}$ uranyl nitrate solutions. These $\mathrm{pH}$ values correspond to molar $\mathrm{NaOH} / \mathrm{U}$ ratios of 1.44 and 0.98 in their respective solutions. This solid has an $X$-ray diffraction pattern similar but not identical to uranyl hydroxide (hydration state not specified), and had a molar $\mathrm{Na} / \mathrm{U}$ ratio of $0.282 \pm 0.05$. This ratio is consistent with a uranate having the formula $\mathrm{Na}_{2} \mathrm{U}_{7} \mathrm{O}_{22}$. Precipitation of this single sodium uranate continued until approximately a pH of 6 . From the $\mathrm{pH}$ value of 6 to 10 (corresponding to molar $\mathrm{NaOH} / \mathrm{U}$ ratios of 2.3 and 2.86 ), the $\mathrm{Na} / \mathrm{U}$ ratio of the precipitate increased continuously from 0.282 to 0.862 . The $\mathrm{Na} / \mathrm{U}$ ratio of the solid remained constant at $0.862 \pm 0.006$ in solution with $\mathrm{pH}$ values greater than 10. Th1s latter ratio was interpreted by Wamser et al. (1952) as being the uranate $\mathrm{Na}_{6} \mathrm{U}_{7} \mathrm{O}_{24}$. $X$-ray diffraction analysis of the precipitates formed in the solutions between $\mathrm{pH}$ values of 6 and 10 indicated the solids were mixtures of $\mathrm{Na}_{2} \mathrm{U}_{7} \mathrm{O}_{22}$ and $\mathrm{Na}_{6} \mathrm{U}_{7} \mathrm{O}_{24}$. Wamser et al. (1952) were unable to precipitate $\mathrm{Na}_{2} \mathrm{U}_{2} \mathrm{O}_{7}$ or $\mathrm{UO}_{2}(\mathrm{OH})_{2}$ in their mixtures of uranyl nitrate and sodium hydroxide solutions: The possible formation of schoepite $\left(\mathrm{UO}_{3} \cdot 2 \mathrm{H}_{2} \mathrm{O}\right)$ was not discussed by wamser et al. (1952).

The uranium validation study included solution compositions taken from Table I and the titration curve in Figure 1 in wamser et al. (1952)." The modeled analyses do not include the precipitation experiments completed in the 0.51 M uranyl nitrate solutions, because their compositions exceed the limit for ionic strength corrections in WATEQ4. Moreover, the solution compositions and $\mathrm{pH}$ values reported by Wamser et al. (1952) are those for the initial mixture of uranyl nitrate and sodium hydroxide solutions. The concentrations of sodium and uranium used to model these experiments, therefore, will represent their total concentrations in the final solution and precipitate. values of $\mathrm{EH}^{\mathrm{H}}$ were not reported.

\section{FIELD STUDIES}

Two published ground-water studies were identified for use in the uranium validation study. The critical aspect of these studies was that the water 
analyses included analytical measurements of $\mathrm{pH}, \mathrm{E}^{\mathrm{H}}$, and temperature, as well as the concentrations of the important dissolved constituents (including uranium).

Chatham, Wanty, and Langmuir (1981) and Wanty, Langmuir, and Chatham (1981)

Chatham, Wanty, and Langmuir (1981) and Wanty, Langmuir, and Chatham (1981) investigated the use of geochemical modeling versus single-element tracer methods, with respect to ground-water prospecting for uranium deposits in sandstone formations. These investigators chemically analyzed and modeled water samples that were collected from aquifers associated with sandstone-type uranium deposits.in. Texas and Wyoming. Their study appears to be an extension of an earlier modeling study (Langmuir and Chatham 1980) in these two:study areas, which relied on estimated $E^{H}$ values for the interpretation of solubility equilibria. However, only those water samples that were noted by Chatham, Wanty, and Langmuir (1981) as being from a known ore zone at the Texas site were used for the uranium validation study, because the general uranium mineralogy is known and the water analyses include onsite measurements of $\mathrm{pH}$, $E_{P t}^{H}$, and temperature.

Chatham, Wanty, and Langmuir (1981) describe the geology and hydrology of their study area. (the 0akville site) near the southern coast of Texas. Water silmples were collected from 46 wells at the 0akville site, which penetrated the basal sandstone in the Oakville Formation. At this locality, this sandstone is the primary horizon, for uranium ore. The Oakville Formation generally consists of tuffaceous sands which contain some coarse, cross-bedded fluvial channels. The uranium ore deposits in this formation consist of uraninite $\left(\mathrm{UO}_{2}\right)$ and coffinite $\left(\mathrm{USiO}_{4}\right)$.

Collection and analytical methods used for the ground waters from the study areas in Texas and Wyoming are described in Chatham, Wanty, and Langmuir (1981, Tables 3, 4, and 5). Samples collected for uranium analysis were passed through a $0.45-\mu \mathrm{m}$ Millipore ${ }^{\circledR}$ filter and acidified to $\mathrm{pH}=1$ with concentrated nitric acid. The concentration of uranium was determined with a fluorimetric

(3) Millipore is a registered trademark of the Millipore Corporation, Bedford, Massachusetts. 
technique that has a detection limit of $0.1 \mu \mathrm{g} \mathrm{L}^{-1}$. Values of $\mathrm{pH}$ were determined onsite with a combination $\mathrm{pH}$ electrode and a field $\mathrm{pH}$ meter. Onsite measurements of $E_{P t}^{H}$ were determined with calomel and platinum electrodes in a special flow-through cell. After the water flow had stabilized, the flow was stopped and the final E⿰亻 (1981, Table 5) report accuracies of $\pm 0.05 \mathrm{pH}$ units and $\pm 10 \mathrm{mV}$, respectively, for their $\mathrm{pH}$ and $\mathrm{E}_{\mathrm{t}}$ measurements. [See Chatham, Wanty, and Langmuir (1981) for descriptions of the analytical methods used for the other dissolved constituents].

Nine water samples [designated as T4, T31 to T37, and T42 in Chatham; Wanty, and Langmuir (1981)] were used in the uranium validation study. According to Plate 1 in Chatham, Wanty, and Langmuir (1981), these waters were collected from wells that are associated with known sandstone-type uranium deposits. The chemical analyses for these nine waters were taken from Chatham, Wanty, and Langmuir (1981, Appendix I) and are tabulated in Table H.9. of the: present report. Mineralogy for core samples from these wells was not reported.

Păces (1969)

Păces (1969) investigated the probable chemical equilibria controlling the compositions of ground waters associated with the Jachymov ore deposit in Czechoslovakia. The results of Păces (1969) are based on analyses of water samples collected on the surface, in several levels of the Svormost mine (Jachymov; Czechoslovakia), and from a drill hole in granite adjacent to this mine. The general geology of the region includes a granite massif overlain by metamorphic rocks, which are commonly biotite-muscovite schisis. Upjer sections of velns of the Jachymov ore deposit that cut the metamorphic complex contain native metals (e.g., silver and b1smuth) and severdl arsenide and sulfide minerals, as well as the gangue minerals dolomite, calcite, and quartz. The lower veins, especially where they exist in granite, include uraninite $\left(\mathrm{UO}_{2}\right)$ and decreased quantities of the carbonate minerals as compared to the upper veins (Păces 1969, p. 593). No additional details were provided as to the extent of the uranium mineralization. 
TABLE H.9a. Solution Analyses Modeled from Chatham, Wanty, and Langmuir (1981). [Sample numbers correspond to same sample numbers as in Appendix I of Chatham, Wanty, and Langmuir (1981).]

\begin{tabular}{|c|c|c|c|c|c|c|c|c|c|c|}
\hline & $\mathrm{pH}$ & $E_{\mathrm{Pt}}^{\mathrm{H}}$ & $T$ & $\mathrm{Na}^{+}$ & $\mathrm{K}^{+}$ & $\mathrm{Ca}^{2+}$ & $\mathrm{Mg}^{2+}$ & $\mathrm{H}_{4} \mathrm{SiO}_{4}^{\circ}$ & $\mathrm{SO}_{4}^{-2}$ & $\mathrm{Cl}^{-}$ \\
\hline & & (V) & $10^{\circ} \mathrm{C}$ & & & & $n$ & & & $\cdots$ \\
\hline T4 & 6.5 & -0.124 & 25 & 470.0 & 22.0 & & 29.0 & 89.6 & 660.0 & 900.0 \\
\hline T31 & 6.9 & -0.1 & 25 & & 17.0 & & 19.0 & 80.0 & 450.0 & 300.0 \\
\hline T32. & 7.0 & -0.22 & 25 & & 19.0 & & & & & 520.0 \\
\hline T33 & 6.8 & -0.23 & 25 & & 27.0 & & 42.0 . & 70.4 & 840.0 & 420.0 \\
\hline T34 & 7.1 & -0.203 & 25 & 440.0 & 21.0 & 180.0 & 21.0 & 80.0 & 750.0 & 400.0 \\
\hline T35 & 7.0 & -0.22 & 25 & & 16.0 & & 9.0 & 83. & 80.0 & 500.0 \\
\hline T36 & 6.9 & -0.206 & 25 & 270.0 & 19.0 & 360.0 & 30.0 . & 86.0 & 810.0 & 440.0 \\
\hline T37 & 6.8 & -0.199 & 25 & 250.0 & 21.0 & 330.0 & 33.0 & 78.0 & & 390.0 \\
\hline 42 & & -0.050 & 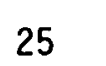 & 320.0 & 15.0 & 650.0 & 29.0 & 65.6 & 1300.0 & 810.0 \\
\hline
\end{tabular}

Sample Number

T4

T31

T32

T33

T34

T35

T36

T37

T42
$\frac{\mathrm{CO}_{3}^{-2}}{\mathrm{N0}_{3}^{-}} \frac{\mathrm{F}^{-}}{\mathrm{Fe}^{2+}} \frac{\mathrm{HS}^{-}}{\mathrm{ppm}} \frac{\mathrm{Mn}^{2+}}{\mathrm{U0}_{2}^{2+}} \frac{\mathrm{VO}_{2}^{+}}{-}$

$\begin{array}{llllllll}307.0 & 7.6 & 0.5 & 0.11 & 9.7 & 0.18 & 0.0001 & 0.033\end{array}$

$\begin{array}{llllllll}354.0 & 4.1 & 0.5 & 0.06 & 9.7 & 0.12 & 0.0015 & 0.002\end{array}$

$\begin{array}{llllllll}284.0 & 5.1 & 0.4 & 0.06 & 9.7 & 0.07 & 0.0002 & 0.007\end{array}$

$\begin{array}{llllllll}257.0 & 4.8 & 0.6 & 0.05 & 9.7 & 0.11 & 0.0005 & 0.005\end{array}$

$\begin{array}{llllllll}289.0 & 5.8 & 0.4 & 0.17 & 9.7 & 0.09 & 0.0003 & 0.007\end{array}$

$\begin{array}{llllllll}274.0 & 5.0 & 0.4 & 0.16 & 9.7 & 0.10 & 0.0007 & 0.010\end{array}$

$\begin{array}{llllllll}298.0 & 5.7 & 0.6 & 0.04 & 9.7 & 0.17 & 0.11 & 0.008\end{array}$

$\begin{array}{llllllll}277.0 & 4.2 & 0.6 & 0.15 & 9.7 & 0.15 & 0.0007 & 0.008\end{array}$

$\begin{array}{llllllll}270.0 & 7.0 & 0.4 & 2.20 & 0.97 & 0.39 & 0.023 & 0.016\end{array}$ 
TABLE H.9b. Saturation Indices for Selected Uranium Solids for Solution Analyses Modeled from Chatham, Wanty, and Langmuir (1981)." [Sample numbers correspond to same sample numbers as in Appendix I in Chatham, Wanty, and Langmuir (1981).]

Saturation Indices

\begin{tabular}{|c|c|c|c|c|c|c|c|}
\hline $\begin{array}{l}\text { Sample } \\
\text { Number }\end{array}$ & Uraninite & Coffinite & $\mathrm{UO}_{2}(\ddot{\mathrm{am}})$ & $U_{4}{ }^{0} g(c)$ & $U_{3}{ }^{0}{ }_{8}(c)$ & Schoepite & $\begin{array}{l}\text { Ruther - } \\
\text { fordine }\end{array}$ \\
\hline$T 4$ & 1.815 & 1.726 & -3.82 & 0.643 & -12.16 & -8.72 & -8.27 \\
\hline T31 & 2.617 & 2.48 & -3.02 & 2.89 & -11.67 & -8.88 & -8.64 \\
\hline T32 & 1.637 & $1.480^{\circ}$ & -4.00 & -2.41 & -17.4 & -11.2 & $-11: 2$ \\
\hline T33 & 2.229 & 2.03 & -3.40 & -0.953 & -17.4 & -11.6 & -11.4 \\
\hline T34 & 1.711 & $1.571^{\circ}$ & -3.92 & -1.24 & -15.4 & -10.3 & -10.3 \\
\hline T35 & 2.176 & 2.05 & -3.46 & -0.190 & -15.6 & -10.6 & -10.6 \\
\hline T36 & 4.47 & 4.36 & -1.162 & 9.3 & -8.1 & -8.0 & -7.9 \\
\hline T37 & 2.376 & 2.22 & -3.26 & 0.951 & -14.4 & -10.1 & -9.9 \\
\hline T42 & 3.13 & 2.91 & -2.50 & 9.01 & -2.00 & -4.3 & $-4 . i$ \\
\hline
\end{tabular}


Păces (1969, Table 1) reports extensive chemical analyses, including values of $\mathrm{pH}, \mathrm{EP}_{\mathrm{Pt}}^{\mathrm{H}}$, and temperature, for eight ground waters at the. Svormost mine. The four analyses that contain concentrations of uranium were used for the uranium validation (Table H.10). Three of these waters were collected from seepages at the tenth and twelfth levels of the mine, and the fourth sample was obtained from a drill hole in the granite, adjacent to the twelfth level of the mine. Water samples were collected in such a way as to minimize their contact with air upstream of the sampling point. Methods for the chemical analysis of the water samples were not described by Păces (1969), but were referenced as being the standard methods of the Geological Survey of Czechoslovakia. Values of $\mathrm{pH}$ and $\mathrm{E}_{\mathrm{Pt}}^{\mathrm{H}}$ were determined by direct immersion of the electrodes into the waters at their sampling points. 
TABLE H.10a. Solution Analyses Modeled from Păces (1969). [Jample numbers correspond to same sample numbers as in Table 1 of Păzes (1967).]

\begin{tabular}{|c|c|c|c|c|c|c|c|c|c|c|c|c|}
\hline $\begin{array}{l}\text { Sample } \\
\text { Number }\end{array}$ & $\mathrm{pH}$ & $\mathbf{E}_{\mathrm{Pt}}^{\mathrm{H}}$ & $\mathrm{T}$ & $\mathrm{Na}^{+}$ & $k^{+}$ & $\mathrm{Li}^{+}$ & $\mathrm{Mg}^{2+}$ & $\mathrm{Ca}^{2+}$ & $\mathrm{Cl}^{-}$ & $\mathrm{CO}_{3}^{2-}$ & $\mathrm{SO}_{4}^{2-}$ & $\mathrm{PO}_{4}^{3-}$ \\
\hline & & $(V)$ & $\left({ }^{\circ} \mathrm{C}\right)$ & --- & & & & $n g L^{-1}$ & & & & \\
\hline 20 & 6.55 & -0.005 & 17.6 & 22.0 & 5.0 & 0.10 & 51.1 & 119.8 & $16: 7$ & 141.03 & 394.6 & 0.613 \\
\hline 21 & 7.15 & $0 . C 56$ & 20.0 & 51.0 & 4.0 & 0.15 & 71.5 & 256.5 & 10.6 & 180.08 & 862.9 & 0.287 \\
\hline 23 & 7.80 & $-0 . C 89$ & 23.4 & 105.0 & 4.5 & 0.17 & 8.5 & 38:.1 & .5 .3 & 361.82 & 54.3 & -- \\
\hline 30 & 6.75 & 0.0153 & 29.8 & 140.5 & 8.5 & 0.15 & 5.5 & 23.6 & 12.4 & 434.5 & 15.6 & 0.208 \\
\hline
\end{tabular}


TABLE H.10b. Saturation Indices for Selected Uranium Solids for Solution Analyses Modeled from Păces (1969). [Sample numbers correspond to same sample numbers as in Table 1 of Păces (1969).]

Saturation Indices

\begin{tabular}{|c|c|c|c|c|c|c|c|}
\hline $\begin{array}{l}\text { Sample } \\
\text { Number }\end{array}$ & Uraninite & Coffinite & $\mathrm{UO}_{2}(\mathrm{am})$ & $U_{4} 0_{9}(c)$ & $\mathrm{U}_{3} \mathrm{O}_{8}(\mathrm{c})$ & Schoepite & $\begin{array}{l}\text { Ruther- } \\
\text { fordine }\end{array}$ \\
\hline 20 & 3.12 & 2.53 & -2.65 & 9.5 & -1.11 & -3.79 & -3.57 \\
\hline 21 & 2.13 & 1.59 & -3.60 & 9.03 & 2.95 & -1.28 & -1.50 \\
\hline 23 & 2.58 & 2.47 & -3.08 & 7.38 & -2.55 & -4.27 & -4.81 \\
\hline 30 & -1.42 & -1.69 & -6.97 & -5.19 & -7.58 & -4.82 & -4.46 \\
\hline
\end{tabular}




\section{DISTRIBUTION}

No. of

Copies

OFFSITE

27 DOE Technical Information Center

Don Alexander

U.S. Nuclear Regulatory

Commission

MS 905-SS

High Level Waste Tech. Development

Washington, DC 20555

John A. Apps

Lawrence Berkeley Laboratory

University of California

One Cyclotron Road

Building 90/1140C

Berkeley, CA 94720

Argonne National Laboratory

Reference Library

9800 South Cass Avenue

Argonne, IL 60439

10 Battelle Memorial Institute

Office of Nuclear Waste

Isolation

505 King Avenue

Columbus, $\mathrm{OH} 43201$

Attn: Beverly Rawles

Gary Beall

Radian Corporation

8500 Shoal Creek

Austin, TX 78766

Larry Benson

Lawrence Berkeley Laboratory

University of California

One Cyclotron Road

Building 90/1140G

Berkeley, CA 94720
No. of

Copies

George Birchard

Nuclear Regulatory Commission

Office of Nuclear Research

Mailstop 1130-SS

Washington, DC 20555

Dr. John Bird

Geology Department

Cornell University

Ithaca, NY 14853

Earnest Bondietti

Environmental Sciences Division

Oak Ridge National Laboratory

Bidg. 1505

Oak Ridge, TN 37830

A. Brandstetter

Office of Nuclear Waste Isolation

Battelle Memorial Institute

505 King Avenue

Columbus, $\mathrm{OH} 43201$

Brookhaven National Laboratory

Reference Section

Information Division

Upton, Long Island, NY 11973

Douglas G. Brookins

Department of Geology

University of New Mexico

Albuquerque, NM 87131

J. L. Burnett

DOE Office of Basic Energy Sciences

Washington, DC 20545

Wayne Carbiener

Office of Nuclear Waste

Isolation

Battelle Memorial Institute

505 King Avenue

Columbus, $\mathrm{OH} 43201$ 
No. of

Copies

Leslie Casey

DOE-NPPO

505 King Avenue

Columbus, $\mathrm{OH} 43201$

H. Clyde Claiborne

Oak Ridge National Laboratory

Nuclear Waste Management Group

Upton, NY 11973

Carl R. Cooley

DOE Division of Waste Isolation

Washington, DC 20545

Jared Davis

U.S. Nuclear Regulatory Commission

Washington, DC 20555

Stan Davis

6549 W. Box Cyn Ur.

Tucson, AZ 85705

Les Dole

Uak Kidge National Laboratory

P.0. Box $X$

Oak Ridge, TN 37830

R. G. Dosch

Sandia Laboratories

Division 4512

Albuquerque, NM 87185

Goeffrey Elchholz

Regent's Professor of Nuclear Engineering

School of Nuclear Engineering Georgia Institute of Technology Atlanta, GN 30332

Warren Eister

DOE Division of Waste Isolation Washington, DC 20545
No. of

Copies

Environmental Protection Agency

Office of Radiation Programs

Technical Assessment Division AW559

Washington, DC 20460

Bruce R. Erdal

Los Alamos Scientific Laboratory

CNC-11, MS-514

Los Alamos, NM 87545

Sherman Fried

Argonne National Laboratory

9700 South Cass Avenue

Argonne, IL 60439

A. Friedman

Argonne National Laboratory

9700 South Cass Avenue.

Argonne, IL, 60439

Alex Gancarz

Los Alamos Scientific

Laboratory

CNC-11, Mailstop 514

Los Alamos, NM 87545

Robert G. Garvin

E. I. duPont deNemours Col. Savannah River Laboratory

Aiken, SC 29801

Richard L. Hahn

nak Ridge National Laboratory

P.0. Box $X$

Oak Ridge, TN 37830

R. J. $\mathrm{Hall}$

Offir.e of Nuclear Waste

Isolation

Battelle Memorial Institute

505 King Avenue

Columbus, OH 43201 
No. of

Copies

Phillip Helmke

1525 Observatory $\mathrm{Dr}$.

University of Wisconsin

Madison, WI 53706

Bill Highland

Dames \& Moore

Suite 200

250 E. Broadway

Salt Lake City, UT 84717

Peter Hoffman

Office of Nuclear Waste

Isolation

505 King Avenue

Columbus, $\mathrm{OH} 43201$

H. D. Holl and

Dept. of Geological Sciences

Harvard University

Cambridge, MA 02138

Norman Hubbard

Office of Nuclear Waste Isolation

Battelle Memorial Institute

505 King Avenue

Columbus, $\mathrm{OH} \quad 43201$

Dana Isherwood

Lawrence Livermore Laboratory

P.0. Box 808

MSL-224

Livermore, CA 94550

J. K. Johnstone

Sandia Laboratories

Albuquerque, NM 87107

G. R. Kilp

Advanced. Energy System

Division

Westinghouse Electric Corp.

P.0. Box 10864

Pittsburgh, PA 15236
No. of

Copies

John F. Kircher

Office of Nuclear Waste Isolation

Battelle Memorial Institute

505 King Avenue

Columbus, $\mathrm{OH} 43201$

George A. Kolstad

DOE Division of Energy. Research

Washington, DC 20545

Kurt Kraus

110 Ogontz Lane

Oak Ridge, TN 37830

Don Langmuir

Dept. of Chemistry and Geochemistry

Colorado School of Mines

Golden, C0 80401

Ron Lantz

Intera Environmental

Consultants

11999. Katy Freeway

Suite 610

Houston, TX 77079

R. B. Laughon

Office of Nuclear. Waste Isolation

Battelle Memorial Institute

505 King Avenue

Columbus, OH 43201

Lawrence Berkeley Laboratory

Reference Library

University of California

Berkeley, CA 94720

Lawrence Livermore Laboratory

Reference Library

P.0. Box 808

Livermore, CA 94550 
No. of

Copies

Stan E. Lgogan

Los Alámos Technical

Associates, Inc.

P.0. Box 410

Los Alamos, NM 87.544

Tom Longo

DOE Division of Waste Isolation

Washington, DC 20545

Los Alamos Scientific Laboratory

Reference library

P.0. Box 1663

Los Alámos, NM 87544

Richard W. Lynch

Manager, Department 4530

Sandià Laboratories

P.0. Box 5800

Albuquerque, NM 87185

I. Wendell-Marine

E. I. duPont deNeumours Co. Savannah River Laboratory

Aiken, SC 29801

J. B. Martin

Asst. Director for Radioactive Waste Mgmt. Branch

NRC Division of Materials and Fuei cycle Fac1l1ty Licensing

Wasington, DC 20555

Jeff L: Means

Battelle Columbus Laboratory

$505 \mathrm{King}$ Avenue

Columbus, $\mathrm{OH} \quad 43201$

Robert E. Meyer

Oak Ridge National Laboratory

P.0. Box $X$

Oak Ridge, TN 37830
No. of

Copies

Martin A. Molecke

Nuclear Waste Experimental

Programs

Division 4512

Sandia Laboratories

Albuquerque, NM 87185

J. E. Monsees

Office of Nuclear: Waste Isolation

Battelle Memorial Institute 505 King Avenue

Columbus, $\mathrm{OH} 43201$.

J. B. Moody

Office of Nuclear Waste Isolation

Battelle Memorial Institute

505 King Avenue

Columbus, $\mathrm{OH} 43201$

Jim P. Murray

Harvard University

Pierce Hall

Cambridge, MA 02138

R. L. Nebeter

Exxon Nuclear Idaho

P. 0. Box 2800

Idaho Falls, ID 83401

Jeff 0. Neff

DOE Columbus Program Office

$505 \mathrm{~K}$ ing Avènue

Columbus, $\mathrm{OH} 43201$

Jim Neilieisel

Environmental Protection Agency

$\mathrm{CM}=2$, Office of Radiation

Program, ANR 460

Washington, DC 20460

Edward Norris

Los Alamos Scientific Laboratory

Group CNC-11 MS-514

P.0. Box 1663

Los Alamos, NM 87545 
No. of

Copies

E. J. Nowak

Sandia Laboratory

Division 5824

Albuquerque, NM 87185

Oak Ridge National Laboratory

Central Research Library

Document Reference Section

Oak Ridge, TN 37830

Edward 0'Donnell

U.S. Nuclear Regulatory

Commission

Office of Standards Development

Washington, DC 20555

W. M. Pardue

Office of Nuclear Waste

Isolation

Battelle Memorial Institute

505 King Avenue

Columbus, $\mathrm{OH} 43201$

George A. Parks

Stanford University

Department of Applied Earth

Sciences

Stanford, CA 94305

L. D. Ramspott

Lawrence Livermore Laboratory

P.0. Box 808

Livermore, CA 94550

Gary A. Robbins

Department of Geology

Texas A\&M Unversity

College Station, TX

John B. Robertson:

USGS National Center

Office of Radiohydrology

MS-410

Reston, VA 20292
No. of

Copies

R. A. Robinson

Office of Nuclear Waste

Isolation

Battelle Memorial Institute

505 King Avenue

Columbus, $\mathrm{OH} 43201$

Savannah River Laboratory

Reference Library.

Aiken, SC 29801

Martin Seitz

Argonne National Laboratory. 9700 South Cass Avenue

Argonne, IL 60439

Robert Silva

Lawrence Berkeley Laboratory

University of California

One Cyclotron Road

Building 70A/1160

Berkeley, CA 94720

David B. Stewart

National Center 959

U.S. Geological. Survey

Reston, VA 22092

Daryl Tweeton

U.S. Bureau of Mines

P.0. Box 1660

Twin Cities, MN 55111

Robert L. Watters

DOE Division of Ocological

Sciences

Washington, DC 20545

H. Weed

Lawrence Livermore Laboratory

P.0. Box 808, MS-L233

Livermore, CA 94550

Allen J. Weiss

Brookhaven National Laboratory

Building 197-C

Upton, NY 11973 
William B. White

Materials Research Laboratory

Pennsylvania State University

University Park, PA 16802

R. F. Williams

Electric Power Research Institute

3412 Hillview Avenue

P.0. Box 10412

Palo Alto, CA 94303

W. A. Willidills

Office of Radiation Programs

Environmental Protection Agency

Washing̣ton, DC 20460

Wilste Library

U.S. Nuclear Regulatory Commission

Wasington, DC 20555

P. S. Witherspoon

University of California Berkeley

Geologic Engineering

1842 Montérey Avernue

Berkeley CA 94707

T. J. Wolery

Lawrence Livermore Laboratiory

P.0. Box 808

Livermore, CA 94550

Kurt Wolfsberg

Los Alamos Scientific

Laboratory

CNC $-11, M S-514$

Los Alamos, NM 97545

H. Tom Yolken

National Bureau of Standards

Physics Building/B320

Wasingtion, DC 20234
ONSITE

5 DOE Richland Operations Office

0. J. Elgert

H. E. Ransom

J. J. Schreiber

F. R. Standerfer.

M. W. Shupe

9 Rockwel1 Hanford Operations
G. S. Rarney
D. Brown
C. H. Delgard
R. B. Kasper
W. H. Price
R. C. Routson
P. F. Salter
M. J. Smith
M. I. Wood

Hanford Engineering Development Laboratory

R. J. Cash

105 Pacific Northwest Laboratory

L. L. Ames

D. J. Bradley

H. C. Burkholder

D. G. Coles

W. J. Deutsch (5)

F. H. Dove

J. S. Fruchter

G. W. Gee

D. C. Glirvin

J. H. Jarrett

E. A. Jenne $(30)$

F. N. llodges

M. R. Kreiter

K. M. Krupka (35)

W. L. Kuhn 
J. L. MCElroy/

R. E. Night ingale

G. L. McVay

J. E. Mendel

R. A. Peters

D. Rai

J. L. Ryan

R. J. Serne

J. W. Shade

D. R. Sherwood

J. A. Stott lemyre

R. G. Strickert

J. L. Swanson

R. P. Turcotte/D. M. Strachan

J. H. Westsik

Geoscience Research and

Engineering Dept. Library (2)

Technical Information Library (5)

Publishing Coordination (2) 